\title{
An Intensive Archeological Survey of the Owl Hills-Tunstill 138-KV Transmission Line Route
}

Michael L. Mudd

Follow this and additional works at: https://scholarworks.sfasu.edu/ita

Part of the American Material Culture Commons, Archaeological Anthropology Commons, Environmental Studies Commons, Other American Studies Commons, Other Arts and Humanities Commons, Other History of Art, Architecture, and Archaeology Commons, and the United States History Commons

Tell us how this article helped you.

This Article is brought to you for free and open access by the Center for Regional Heritage Research at SFA ScholarWorks. It has been accepted for inclusion in Index of Texas Archaeology: Open Access Gray Literature from the Lone Star State by an authorized editor of SFA ScholarWorks. For more information, please contact cdsscholarworks@sfasu.edu. 


\section{An Intensive Archeological Survey of the Owl Hills-Tunstill 138-KV Transmission Line Route}

\section{Creative Commons License}

\section{(c) (1) \&}

This work is licensed under a Creative Commons Attribution-NonCommercial 4.0 International License 


\section{AN INTENSIVE ARCHEOLOGICAL SURVEY OF THE OWL HILLS-TUNSTILL 138-KV TRANSMISSION LINE ROUTE}

Culberson, Reeves and Loving Counties, Texas

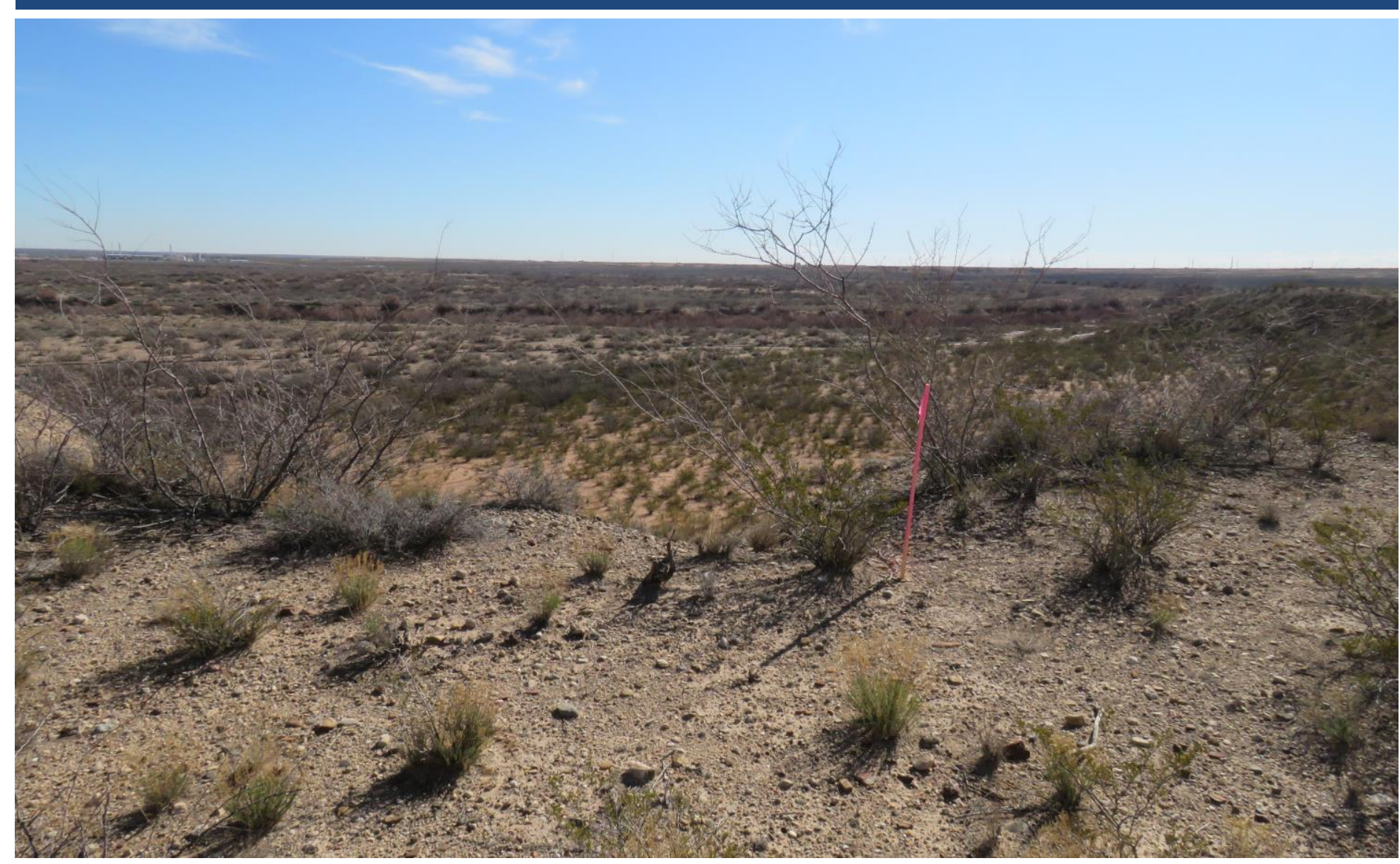

Prepared For:

Oncor Electric Delivery Company, LLC

Prepared By:

Michael L. Mudd, RPA

Principal Investigator

Halff Associates, Inc.

March 2020

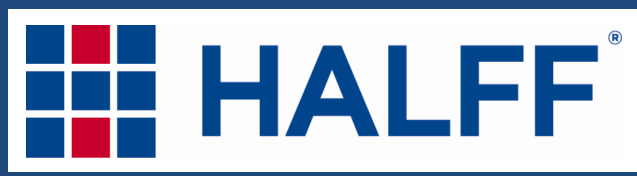


This page intentionally left blank 


\title{
AN INTENSIVE ARCHEOLOGICAL SURVEY OF THE OWL HILLS-TUNSTILL 138-KV Transmission Line RouTE
}

\author{
Culberson, ReEves and Loving Counties, Texas
}

Report Prepared for:

Oncor Electric Delivery Company, LLC

By:

Michael L. Mudd, RPA

Principal Investigator

Halff Associates, Inc

9500 Amberglen Blvd.

Building F, Suite 125

Austin, TX 78729

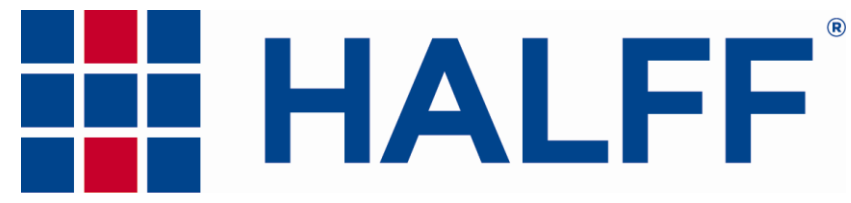

March 2020

AVO 37935 
This page intentionally left blank 


\begin{abstract}
Oncor Electric Delivery Company, LLC (Oncor) is planning to construct the Owl Hills-Tunstill 138-kV Transmission Line Route in Culberson, Reeves and Loving Counties, Texas. Oncor contracted with Halff Associates, Inc. to conduct an intensive pedestrian survey of 18.5 miles of new $138-\mathrm{kV}$ transmission line on private property. The survey was conducted January 20-24, 2020 and a total of 102 shovel tests were excavated in areas where buried archeological deposits where expected, and two 15-meter (32.8-foot) transects underwent pedestrian survey within the 70-foot (21.3-meter) wide survey corridor, which measures approximately 157 acres.

Three archeological sites (41RV208, 41RV209 and 41RV213) were identified and recorded during the archeological survey. Site 41RV208 is a prehistoric occupation containing a surface deposit of 12 lithic debitage, 6 flake tools, 6 cores, 2 groundstone fragments and 40 fire cracked rocks (FCR). The site is situated on a gravelly and deflated upland that forms the western rim of the Pecos River valley. Site 41RV209 consists of a prehistoric occupation containing a surface deposit of 12 FCR, 6 lithic debitage, 3 flake tools, 2 cores, 1 uniface, and 1 biface. This site is situated on the heavily eroded west bank of Salt Creek and has been disturbed by construction activities associated with an adjacent pipeline corridor. Site 41RV213 is an abandoned section of the Atchison, Topeka \& Santa Fe (ATSF) Railway that parallels U.S. Highway 285 to the east. The section of railroad in the surveyed area has undergone extensive disturbance and consists of a narrow linear piling of fill, railroad gravels and non-descript metal debris. It is Halff's recommendation that sites 41RV208, 41RV209 and 41RV213 are ineligible for National Register of Historic Places consideration in the surveyed area and no further cultural resources investigations are warranted for the project.

While shovel testing within the lower terraces of the Pecos River valley floor resulted in negative findings, most of the shovel tests in this area did not encounter restrictive deposits soil or geologic deposits that antedate the Holocene. Therefore, the installation of the transmission line poles located along the lower alluvial terraces of the Pecos River was recommended for archeological monitoring. Halff recommends that construction of the remainder of the proposed transmission line route be allowed to proceed and that no additional archaeological investigations are recommended outside of the monitoring area. However, if the proposed transmission line route alignment changes, additional archeological survey may be necessary. In addition, should any cultural resources be discovered during the construction or maintenance activities associated with the project, work in the immediate area shall cease and the Texas Historical Commission be notified of the discovery.
\end{abstract}




\section{TABLE OF CONTENTS}

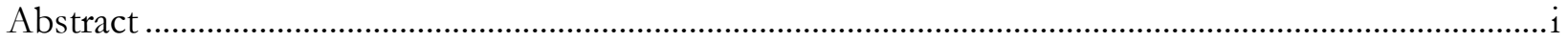

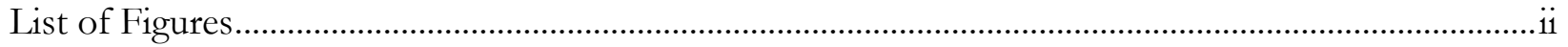

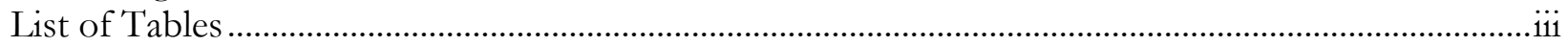

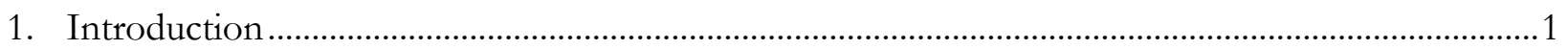

2. Environmental Setting............................................................................................................

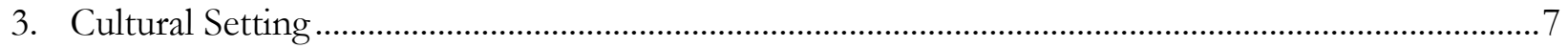

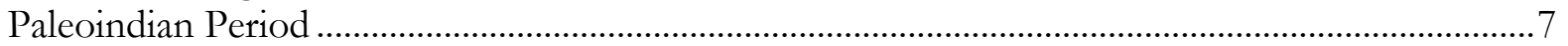

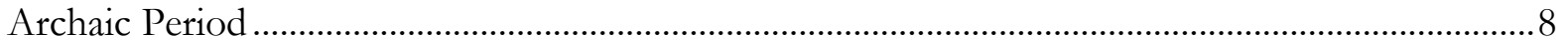

Late Prehistoric Period.................................................................................................................

Historic European Period...................................................................................................................... 9

Previous Cultural Resources Investigations …………………………………………………….10

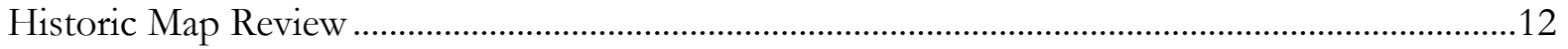

4. Research Design and Methodology ……………………………………………………....13

Research Design ....................................................................................................................13

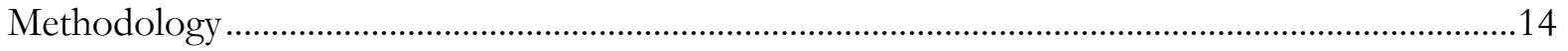

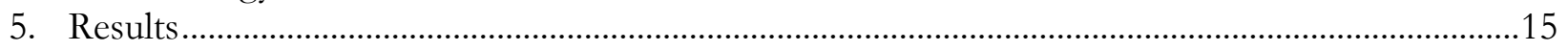

Archeological Sites Documented.....................................................................................................26

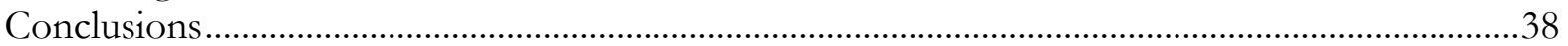

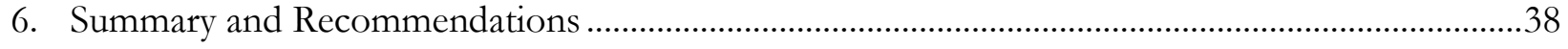

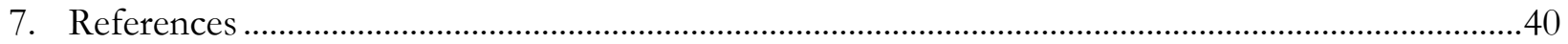

\section{LIST OF FIGURES}

Figure 1: Project Location Map. …………………………………………………………….....

Figure 2: Project Location Topographic Map. ……………………………………………………….

Figure 3: Pecos River valley showing the valley rim in background, looking west.................................6

Figure 4: Gatuna Formation exposed in Salt Creek cutbank profile, looking southwest. ......................6

Figure 5: Previous cultural resources survey areas located in the project vicinity..................................11

Figure 6: 1968 Red Bluff Topographic map showing ATSF Railway....................................................12

Figure 7: Common degree of ground exposure along the Route, looking east......................................15

Figure 8: Example of dense ground cover in low-lying area, looking south..........................................16

Figure 9: Example of pipeline corridor and telephone utility crossing the Route, looking south........16

Figure 10: Shovel test locations along the Pecos River HPA..................................................................17

Figure 11: Shovel tests placed along the Salt Creek drainages HPA......................................................18

Figure 12: Shovel tests placed along the unnamed tributary of Salt Creek HPA....................................19

Figure 13: Shovel tests placed along the Salt Creek/ATSF HPA...........................................................22

Figure 14: Shovel tests locations at the Skinner Draw HPA ………………………………………......2

Figure 15: Common gravelly terrain and ground cover along MPAs...................................................22

Figure 16: Common terrain and ground disturbance along MPAs........................................................22

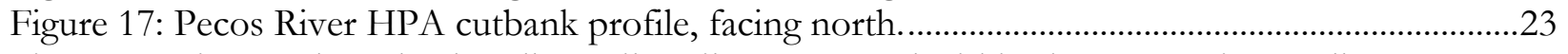

Figure 18: Fine sandy and culturally sterile soil encountered within the Pecos River Valley................23

Figure 19: Common fine sandy soils with shallow gravel deposit in upland areas, looking west........24

Figure 20: Typical view of gravelly upland west of the Pecos River Valley, looking west.....................24

Figure 21: Heavily eroded surface along west bank of Salt Creek, looking southeast............................25

Figure 22: Ground disturbance along east side of Salt Creek, looking northeast. ..................................25

Figure 23: Site location map for 41RV208........................................................................................26 


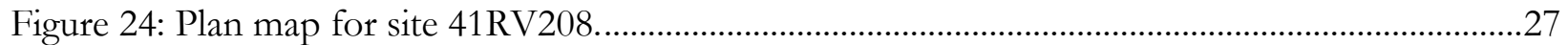

Figure 25: Lithic debitage assemblage from site 41RV208 ...................................................................28

Figure 26: Flake tool assemblage from site 41RV208. .....................................................................28

Figure 27: Exhausted core assemblage from site 41RV208...............................................................29

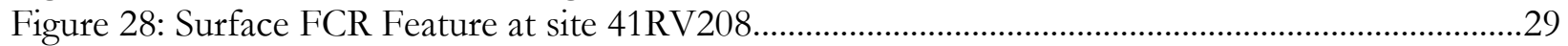

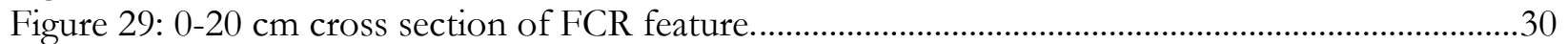

Figure 30: Overview of site 41RV208 from eastern boundary, looking west.........................................30

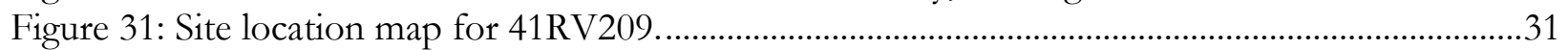

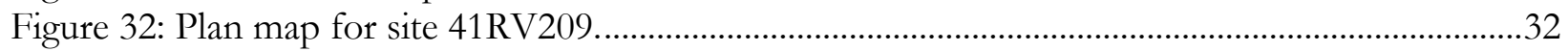

Figure 33: Lithic tool and core assemblage from site 41RV209. ..........................................................33

Figure 34: Surface deposits of FCR and pipeline corridor (right) at site 41RV209, looking east........33

Figure 35: Erosional cuts common at site 41RV209, looking east........................................................34

Figure 36: Overview of site 41RV209 with adjacent pipeline corridor (right), looking west. ..............34

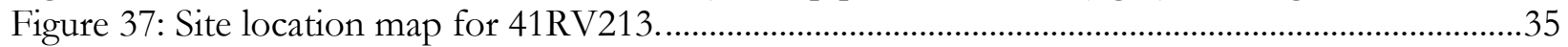

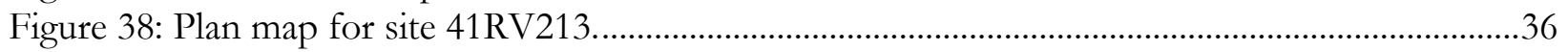

Figure 39: Overview of site 41RV213, showing gravel and scrap metal, facing southeast...................37

Figure 40: Overview of cleared and disturbed areas surrounding site 41RV213, facing north............37

Figure 41: Map of recommended construction monitoring area.............................................................39

\section{LIST OF TABLES}

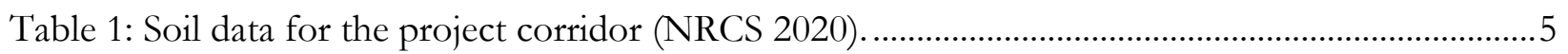




\section{INTRODUCTION}

Halff Associates, Inc. (Halff) conducted an intensive pedestrian archeological survey on behalf of Oncor Electric Delivery Company, LLC (Oncor) for the proposed Owl Hills-Tunstill 138-kV Transmission Line Route in Culberson, Reeves and Loving Counties, Texas. The proposed project includes approximately 18.5 miles of new electric transmission line to be constructed on private land between the existing Owl Hills substation and Tunstill point of delivery (POD) (Figures 1 and 2). The proposed transmission line corridor (Route) traverses privately-owned commercial lands used for agriculture and oil and gas leases, paralleling and intersecting with numerous existing pipeline corridors and lease roads. The Route crosses US Highway 285 approximately 4.5 miles north of the community of Orla, Texas. Construction of the transmission line design includes mechanized land clearing typically to depths of 6 to 24 inches (15 to 60 centimeters [cm]). The depths of pole foundation holes generally impact depths of 10 to 25 feet (ft) (3 to 7.5 meters [m]) and have a diameter of 2 to $5 \mathrm{ft}(0.5$ to $1.5 \mathrm{~m})$. In extreme cases, the depth may extend as deep as $60 \mathrm{ft}(18.3 \mathrm{~m})$.

As part of the permitting process for projects of this nature, Oncor applies for a Certificate of Convenience and Necessity (CCN) from the Public Utility Commission of Texas (PUC), as required by Section 37.051 of the Texas Utilities Code (TUC). In granting the CCN, the PUC routinely requests that Oncor comply with the requirements of the Texas Historical Commission (THC) regarding the need for cultural resources investigations within the proposed project area, which generally consists of an intensive pedestrian survey of the project corridor. Halff conducted this survey January 20-24, 2020 in accordance with the THC-approved Generic Research Design for Archaeological Surveys of Oncor Electric Delivery Electric Transmission Line Projects in Texas (PBS\&J 2008). The research design stipulates the methods by which cultural resources within proposed Oncor transmission line corridors will be identified and assessed for National Register of Historic Places (NRHP) eligibility, and how sitespecific recommendations for additional archaeological research should be handled.

This archeological survey report conforms to the Guidelines for Cultural Resource Management Reports used by the Archeology Division of the THC (Council of Texas Archeologists 2020) and those found in the Oncor Generic Research Design (PBS\&J 2008). Following the Introduction, Chapter 2 of this report provides an overview of the project's environmental setting. Chapter 3 provides an overview of the regional cultural history and prior archeological investigations within the project vicinity. Chapter 4 covers the research design and methodology utilized in the investigations. The results of the investigations are presented in Chapter 5 and the report concludes with Chapter 6 , which includes concluding remarks and recommendations regarding further archeological work. 

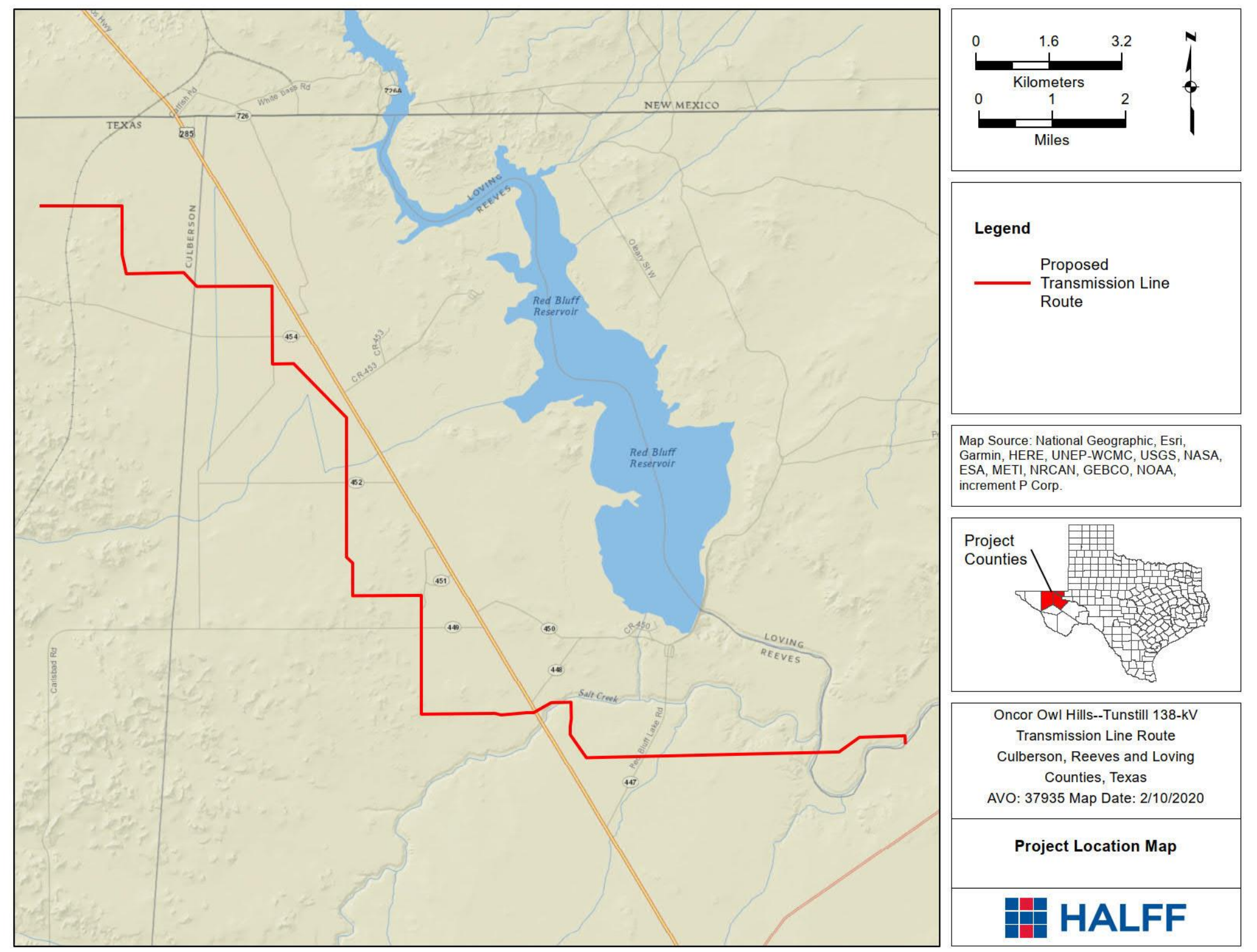

Figure 1: Project Location Map. 

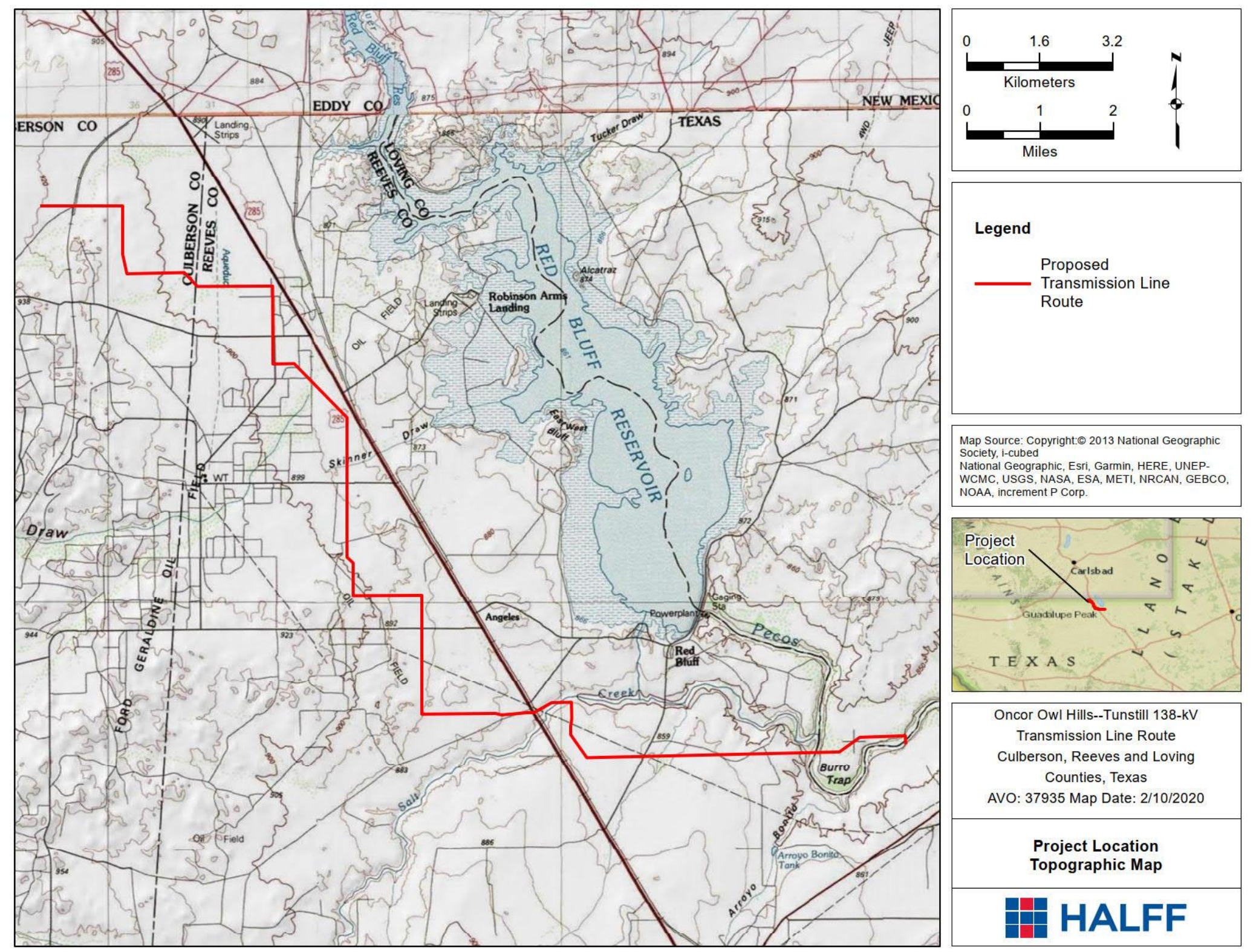

Figure 2: Project Location Topographic Map. 


\section{ENVIRONMENTAL SETTING}

The Owl Hills-Tunstill Transmission Line Project is located in the Chihuahuan Basins and Playas ecoregion of Texas, which consists of relatively low-lying flats, slopes, dunes, basins, hills and ridges with occasional mountains and plateaus (Griffith et al. 2007:8). The region is characterized by low annual rainfall amounts between 8 and 14 inches, soils that are alkaline or gypsiferous, and desert shrub vegetation such as creosote bush and cactus species. Due to the high demand for irrigation and industrial water, the present day flow of the Pecos River, the primary waterway in the region, has been greatly reduced from historical levels, which early travelers described as being wide, deep and fast, and crossable at only a few safe fording points (Graves 2002 cited in Griffith et al. 2007:9).

The southern end of the Route extends westward from the Tunstill POD, traversing the broad Pecos River valley and crossing its narrow stream channel at two separate locations. The area between the two crossings forms the meander side of the river's wide oxbow, which is flanked to the west by a gravelly bluff forming the valley rim (Figure 3). Geologically, this section of the Route is mapped on Pliestocene-age fluviatile deposits composed of gravel, sand and silt (USGS 2020a). Further west of the Pecos, the Route crosses several ephemeral drainages leading up to the crossing at Salt Creek just east of U.S. Highway 285 (US 285). This section of the Route is mapped on the Holocene-age Alluvium geologic deposits with exception to the lower Salt Creek terraces, which are truncated by the Pleistocene-age Gatuna Formation that consists of sand, marl, conglomerate, gypsum, silt, shale and limestone (USGS 2020a; Figure 4). Much of the Route west of US 285 is hydrologically featureless, consisting of alternating sections of the Holocene-age Young Quaternary deposits and the Permianage Rustler Formation, which is composed of limestone, siltstone, sandstone, gypsum, marl and clay.

According to the Natural Resource Conservation Service Web Soil Survey (NRCS 2020), there are eleven soil types mapped along the Route that generally correspond with the geology and physiography of the surrounding terrain (Table 1). For example, the upland outer fringes of the Pecos River valley contain the Delnorte-Chilicotal association, rolling, which consists of Pleistocene-age gravelly alluvium. The entire section within the valley, along the meander deposits of the oxbow, contains the Monahoans-Pajarito complex, nearly level, which is composed of fine sandy loam and sandy clay loam derived from calcareous and gypsiferous alluvium. The soils mapped west of the Pecos River towards Salt Creek consist of the Hoban-Reeves-Holloman association, nearly level, which is characterized by calcareous clay and silty clay loamy alluvium. The eroded lower Salt Creek terraces contain the HobanReeves association, gently undulating, consisting of residuum weathered from gypsum.

The overall topography along the Route west of US 285 is gently undulating and nearly level due to generally more gravelly surfaces and a lack of hydrologic features. The predominate soil associations in this section of the Route consist of Hoban-Reeves-Holloman, Hoban-Reeves, Delnorte-Chilicotal, Reakor-Lozier, and Reaker, all of which formed in plains, hillslope or basin floor settings. Towards the northern end, the topography increases, containing mostly older rocky soils such as the BissettRock outcrop complex, Dellaunt silt loam, and the Elcor-Dellahun-Pokory complex. 
Table 1: Soil data for the project corridor (NRCS 2020).

\begin{tabular}{|c|c|c|c|c|c|c|}
\hline Symbol & Soil Name & Texture & Landform & Parent Material & Acres & Percentage \\
\hline BID & $\begin{array}{l}\text { Bissett-Rock } \\
\text { outcrop complex, } 1 \\
\text { to } 8 \text { percent slopes }\end{array}$ & $\begin{array}{l}\text { very } \\
\text { gravelly } \\
\text { loam, } \\
\text { bedrock }\end{array}$ & Mesas & $\begin{array}{l}\text { Gravelly } \\
\text { residuum } \\
\text { weathered from } \\
\text { limestone }\end{array}$ & 2.2 & $1.4 \%$ \\
\hline DEB & $\begin{array}{l}\text { Dellahunt silt loam, } \\
0 \text { to } 5 \text { percent } \\
\text { slopes, occasionally } \\
\text { flooded }\end{array}$ & \begin{tabular}{|l|} 
silt loam, \\
silty clay \\
loam, \\
silt loam \\
\end{tabular} & $\begin{array}{l}\text { Alluvial } \\
\text { flats }\end{array}$ & $\begin{array}{l}\text { Loamy alluvium } \\
\text { derived from } \\
\text { rock gypsum }\end{array}$ & 5.5 & $3.5 \%$ \\
\hline DNB & \begin{tabular}{|l|} 
Dellahunt- \\
Neimahr-Joberanch \\
complex, 1 to 3 \\
percent slopes
\end{tabular} & $\begin{array}{l}\text { loam, } \\
\text { clay loam, } \\
\text { silt loam }\end{array}$ & $\begin{array}{l}\text { Alluvial } \\
\text { flats }\end{array}$ & $\begin{array}{l}\text { Loamy alluvium } \\
\text { derived from } \\
\text { rock gypsum } \\
\text { and/or sandstone }\end{array}$ & 7.8 & $5.0 \%$ \\
\hline EPA & $\begin{array}{l}\text { Elcor-Dellahunt- } \\
\text { Pokorny complex, } \\
0 \text { to } 2 \text { percent } \\
\text { slopes }\end{array}$ & $\begin{array}{l}\text { gypsiferous } \\
\text { loam, } \\
\text { bedrock }\end{array}$ & Hills & $\begin{array}{l}\text { Residuum } \\
\text { weathered from } \\
\text { rock gypsum }\end{array}$ & 9.6 & $6.1 \%$ \\
\hline HAA & $\begin{array}{l}\text { Harkey-Patrole } \\
\text { association, } \\
\text { occasionally } \\
\text { flooded }\end{array}$ & $\begin{array}{l}\text { loam, } \\
\text { silty loam }\end{array}$ & Floodplain & $\begin{array}{l}\text { Calcareous } \\
\text { coarse-loamy } \\
\text { alluvium }\end{array}$ & 3.5 & $2.3 \%$ \\
\hline MPA & $\begin{array}{l}\text { Monahoans- } \\
\text { Pajarito complex, } \\
\text { nearly level }\end{array}$ & \begin{tabular}{|l} 
fine sandy \\
loam, \\
sandy clay \\
loam \\
\end{tabular} & Plains & $\begin{array}{l}\text { Calcareous and } \\
\text { gypsiferous } \\
\text { alluvium }\end{array}$ & 7.2 & $4.6 \%$ \\
\hline 12 & $\begin{array}{l}\text { Delnorte-Chilicotal } \\
\text { association, rolling }\end{array}$ & $\begin{array}{l}\text { gravelly } \\
\text { loam, } \\
\text { very } \\
\text { gravelly } \\
\text { loam, } \\
\text { bedrock }\end{array}$ & $\begin{array}{l}\text { Fan } \\
\text { piedmonts }\end{array}$ & $\begin{array}{l}\text { Pleistocene-age } \\
\text { gravelly alluvium }\end{array}$ & 16.7 & $10.7 \%$ \\
\hline 17 & $\begin{array}{l}\text { Hoban-Reeves- } \\
\text { Holloman } \\
\text { association, nearly } \\
\text { level }\end{array}$ & $\begin{array}{l}\text { clay loam, } \\
\text { silty clay } \\
\text { loam }\end{array}$ & $\begin{array}{l}\text { Basin } \\
\text { floors }\end{array}$ & $\begin{array}{l}\text { Calcareous loamy } \\
\text { alluvium }\end{array}$ & 29.7 & $18.9 \%$ \\
\hline 20 & $\begin{array}{l}\text { Holloman-Reeves } \\
\text { association, gently } \\
\text { undulating }\end{array}$ & $\begin{array}{l}\text { loam, } \\
\text { gypsiferous } \\
\text { material } \\
\end{array}$ & Hillslopes & $\begin{array}{l}\text { Residuum } \\
\text { weathered from } \\
\text { gypsum }\end{array}$ & 23.4 & $14.9 \%$ \\
\hline 32 & $\begin{array}{l}\text { Reakor association, } \\
\text { nearly level }\end{array}$ & $\begin{array}{l}\text { loam, } \\
\text { clay loam }\end{array}$ & Plains & $\begin{array}{l}\text { Fine-silty } \\
\text { alluvium }\end{array}$ & 16.6 & $10.6 \%$ \\
\hline 33 & $\begin{array}{l}\text { Reakor-Lozier } \\
\text { association, } \\
\text { undulating }\end{array}$ & $\begin{array}{l}\text { loam, } \\
\text { clay loam }\end{array}$ & Plains & $\begin{array}{l}\text { Fine-silty } \\
\text { alluvium }\end{array}$ & 33.7 & $21.5 \%$ \\
\hline
\end{tabular}


Intensive Archeological Survey of the

Owl Hills_-Tunstill 138-kV Transmission Line Route

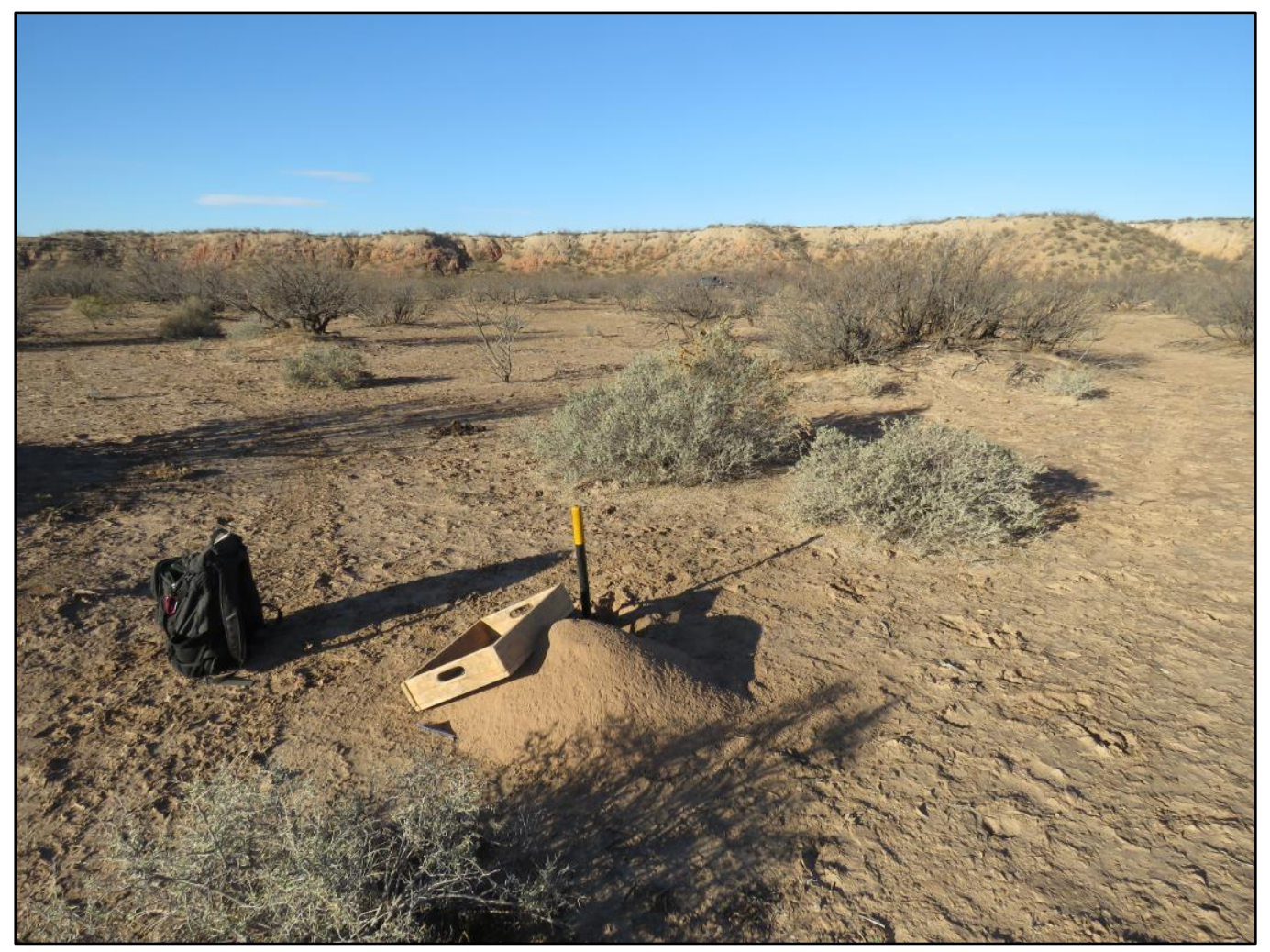

Figure 3: Pecos River valley showing the valley rim in background, looking west.

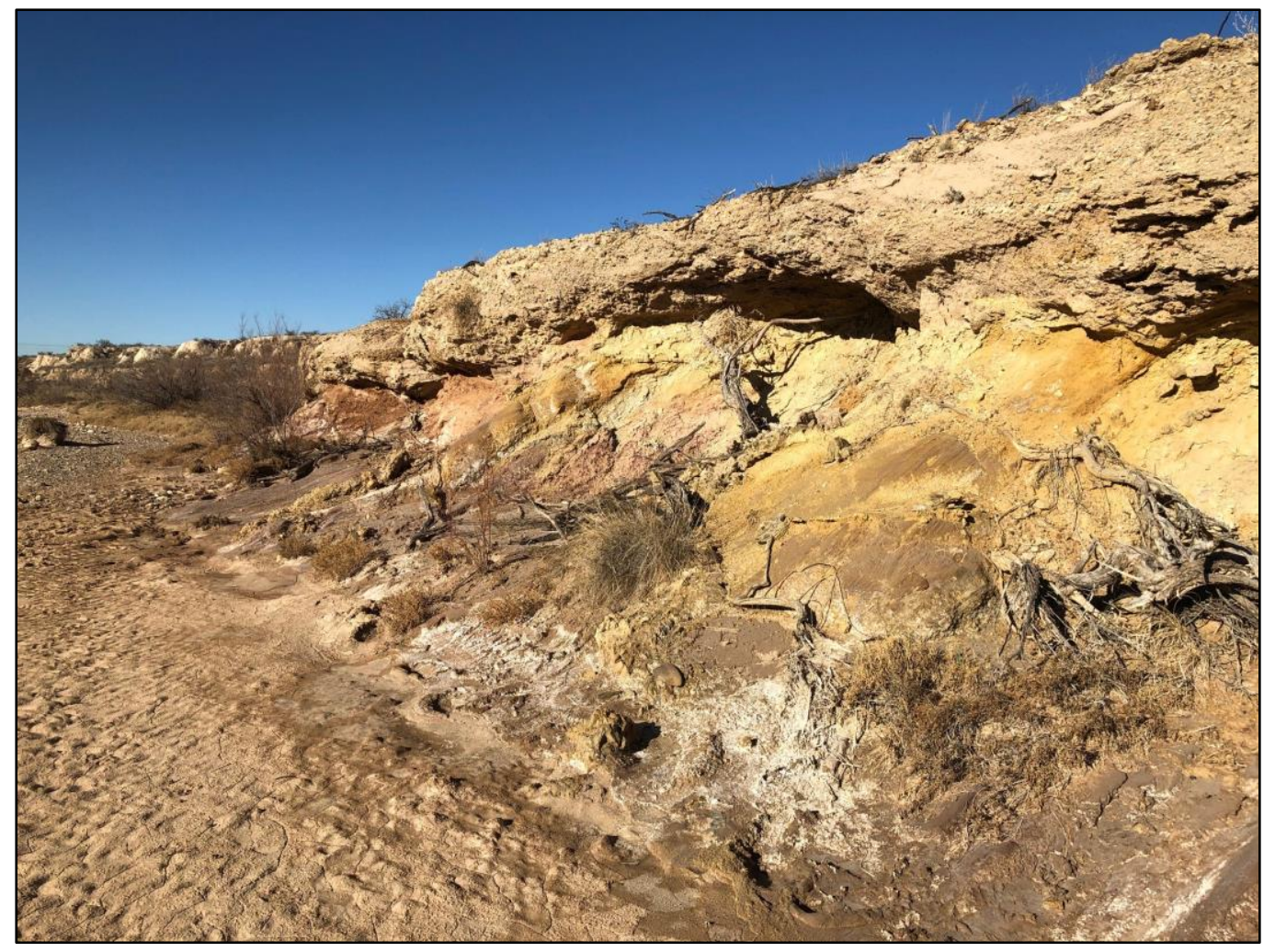

Figure 4: Gatuna Formation exposed in Salt Creek cutbank profile, looking southwest. 


\section{Cultural Setting}

The Trans-Pecos Region of Texas has not been extensively studied, with exception to a few largescale projects, which have provided a general synthesis of the region's cultural chronology. The chronological framework for human occupation in the Eastern Trans-Pecos Region is synthesized by Miller and Kenmotsu (2004:210-211) as follows:

\author{
Period \\ Historic European \\ Late Prehistoric \\ Late Archaic \\ Middle Archaic \\ Early Archaic \\ Paleoindian
}

\author{
Time Interval \\ AD 1450 to 1800 \\ AD $200 / 900$ to 1450 \\ $1200 \mathrm{BC}$ to AD 200/900 \\ 3000 to $1200 \mathrm{BC}$ \\ 6000 to $3000 \mathrm{BC}$ \\ 10,000 to $6000 \mathrm{BC}$
}

\section{Paleoindian Period}

The earliest evidence of prehistoric occupation in the Trans-Pecos is from the Paleoindian period, which is traditionally characterized by small and highly mobile bands with a subsistence economy centered around the hunting of large mammals such as mammoth and bison. The Paleoindian period is associated with distinctive projectile points, with examples from Clovis, Folsom and Plano/Cody complexes that subdivide the Paleoindian period in the Trans-Pecos Region. The earliest stage of the period is known as Clovis, which is poorly represented in the region save for some isolated discoveries of distinctive fluted projectile points associated with the complex (Miller and Kenmotsu 2004). Clovis points have not been found in Culberson, Loving or Reeves County; the nearest areas of Clovis discoveries in the eastern Trans-Pecos are to the south in Brewster and Pecos County (Bever and Meltzer 2007). The lack of Clovis cultural materials could indicate that early inhabitants were widely spread in the eastern Trans-Pecos region, or reflect the dearth of archaeological studies conducted in the region.

In the eastern Trans-Pecos, Folsom discoveries have been reported from the Guadalupe Mountains and east of present-day Van Horn, Texas in the Salt Flat Basin. Much of what is known about the Folsom period occupations in the eastern Trans-Pecos comes from investigations at the Chispa Creek site located in Culberson County (Lindsay 1969). This site contains a Folsom component and is characterized as a temporary occupation indicative of the seasonal hunting and gathering lifeway of early Paleoindian groups. Sommers (1974) provides a comprehensive list of sites, noting concentrations of Paleoindian occupations along the Pecos River valley. East of the Pecos in Loving County, a Folsom component was excavated at site 31LV3, yielding a Folsom point base, a small collection of tools and channel flakes and a large quantity of debitage. The site was situated in eolian deposits some $2 \mathrm{~m}$ deep and the assemblage was found heavily mixed with later Archaic period materials, which is a common issue with Paleoindian sites in the Trans-Pecos due to a variety of postdepositional processes. Given the overall absence of discrete stratigraphic zones and the difficulty in deciphering Paleoindian occupations from subsequent uses of a locality, analyses of Paleoindian stone 
tool assemblages have focused on diagnostic bifacial tools, projectile points, unifacial scrapers and channel flakes coupled with detailed studies of raw material types (Miller and Kenmotsu 2004:216).

The Late Paleoindian period in the eastern Trans-Pecos is manifested in the Plano and Cody complexes, and a variety of tool traditions such as Meserve, Golondrina, and Angostura points. Like the Early Paleoindian Clovis and Folsom complexes, Plano and Cody occupations are not welldocumented and are limited to surface finds across the Trans-Pecos. However, Plano and Cody Complex sites are more common than Clovis and Folsom in the eastern Trans-Pecos, though this may be a product of site visibility and recognition (Miller and Kenmotsu 2004:217). Several small sites containing projectile points attributed to the Plano and Cody Complexes have been found in the Davis Mountains, Big Bend National Park and Ranch, and the Stockton Plateau.

\section{Archaic Period}

Spanning some 6000 years, the Archaic Period is the longest in Texas prehistory and has been conventionally divided into the Early Archaic (6000 to 3000 BC), Middle Archaic (3000 to 1200 BC) and Late Archaic (1200 BC to AD 200/900) subperiods. These subdivisions have been developed primarily based on projectile point variations as well as cultural chronologies defined in adjacent regions of Texas, though no reliable and independently dated projectile point sequence has been developed for the Trans-Pecos (Miller and Kenmotsu 2004:218). Archaic period subdivisions also broadly align to paleoenvironmental and paleoclimatic intervals; thus, the estimated time intervals for the Early, Middle and Late Archaic vary between the eastern and western Trans-Pecos. Mallouf's (1985) prehistoric synthesis of the eastern Trans-Pecos and Sebastian and Larralde's (1989) overview of southeastern New Mexico provide detailed perspectives of indigenous lifeways during the Archaic period.

Despite the continued use of Paleoindian lithic technology, the emergence of a broadly-based hunting and gathering adaptation, especially an increase in evidence of gathering, marks the advent of the Archaic (Lintz et al. 1993:52). The appearance of grinding stones in Archaic period stone tool assemblages suggests the exploitation and processing of plant resources, and the use of stone-lined hearths suggests a refinement in food processing. The appearance of burned rock middens marks the end of the Early Archaic and are the dominate feature of the Middle Archaic, suggesting the increasing importance of food processing and possibly specialized food harvesting. Yucca and sotol are present at numerous Middle Archaic sites, reflecting exploitation of perennial local plant resources and the cyclically xeric climatic conditions of the period (Johnson and Goode 1994:26). The Archaic period is also characterized by a general increase in populations, as evidenced by the increased density of Late Archaic deposits at stratified sites found in the region (Prewitt 1985:217).

An increase in the number of sites during the later portions of this period is attributed to population increases and the region experiencing a wetter and cooler climate. In addition to characteristic broad expanding stem dart points such as Castroville, Marcos and Montell, the Late Archaic, particularly its latter half, is distinguished by settlement, subsistence and technological innovation that closely resemble the subsequent traditions rather than the previous four millennia of Archaic period lifeways. 
The transitionary nature of the Late Archaic can be viewed as a product of regional climatic improvements and increased population densities, which would have propagated the sharing of new technologies and subsistence customs, and increased sedentism possibly in response to circumscribed resource areas and territorial ranges.

\section{Late Prehistoric Period}

The Late Prehistoric period in the Trans-Pecos region represents important transitions in prehistoric settlement adaptations (Miller and Kenmotsu 2004:236). The Late Prehistoric in the eastern TransPecos, or La Junta district, has been subdivided into three general phases, which include the Chisos phase (AD 1 to 900/1000), the Livermore phase (AD 900/1000 to 1200) and the La Junta phase (AD 1200 to 1400). In general, these intervals represent increasingly formal organization of residential settlements and accompanying changes in architectural form, beginning with informal hut and pithouse habitations, moving on to contiguous multi-room pueblo-like structures. Although the eastern Trans-Pecos contained similar architecture and material culture patterns that existed in the Jornada region of western Trans-Pecos, the degree of agricultural dependence in the La Junta region may not have been as pronounced (Miller and Kenmotsu 2004:238).

In addition to a gradual decrease in group mobility, evidenced by semi-permanent and permanent habitation structures, the Late Prehistoric in the Trans-Pecos is characterized by local El Paso plain brown pottery, later monochrome and polychrome wares, and nonlocal ceramics such as Mimbres whiteware and other varieties suggesting increased levels of interaction with groups from neighboring regions over time. Burned rock features during the early part of the period apparently reflect a reliance on wild plant foods, whereas later rock-lined thermal features and storage pits suggest that subsistence practices became more agriculturally specialized during the later La Junta phase, a practice that may have worked in tandem with continued wild plant processing.

The group mobility strategies established during the Late Archaic appear to have waned around the time the bow and arrow were adopted around AD 1000, at the general onset of the Livermore phase. Stone tool assemblages recovered from La Junta phase sites include Toyah, Perdiz, Fresno and Garza arrow points, shallow basin metates, manos, pestles, stone bowls, stone sinkers and scrapers. Sebastian and Larralde (1989) and Miller (1994) postulate that the material culture and temporary nature of architecture at Late Prehistoric sites in the eastern Trans-Pecos represent seasonally mobile groups that periodically moved into the region to gain access to selected resources, perhaps from neighboring regions to the north and west.

\section{Historic European Period}

The Puebloan settlements across the Jornada Mogollon region of the western Trans-Pecos were abandoned between AD 1450 and 1500, and a limited sample of radiocarbon dates suggest that the use of semi-permanent isolated habitation structures discontinued around the same time. This relatively sudden abandonment has been attributed to an extended period of drought and subsistence failure resulting from an economy overspecialized in agriculture. Another scenario proposed by Carmichael (1986) suggests that populations reverted to the less intensive hunting and gathering 
subsistence organization similar to the indigenous practices documented by Spanish explorers during the $16^{\text {th }}$ and early- $17^{\text {th }}$ centuries. It is unclear what events transpired in the Trans-Pecos in the years between the abandonment of the El Paso phases system during the late- $15^{\text {th }}$ century and the influx of Spanish explorers in the mid- to late- $16^{\text {th }}$ century.

Several entradas by Spanish explorers commenced in 1581 and passed through portions of the TransPecos, including the Rodriguez-Chamuscado, Espejo and Oñate expeditions, whose accounts note the presence of indigenous groups occupying the La Junta and western Trans-Pecos regions (Miller and Kenmotsu 2004:259). Everitt (1977) pointed out that such groups were frequently encountered by Spanish explorers during the winter months but found the region devoid of indigenous inhabitants during the summer months, suggesting that mobility was patterned around seasonal settlement rounds. The villages of the La Junta region continued to be occupied until 1683, when Spanish missions were established in the Presidio Bolson (Miller and Kenmotsu 2004:260).

Spanish colonization grew rapidly with the establishment of mission settlements in the eastern TransPecos during the late- $17^{\text {th }}$ century; however, Spanish Colonial period sites in the La Junta region have received little archeological investigation. Much of the Spanish settlement during this period was focused along floodplain and terrace margins of the Rio Grande Valley, with residential areas centered in proximity to missions. The early periods of Spanish colonization in the Trans-Pecos, though only cursorily understood, can be characterized as a period of dynamic and complex relationships between indigenous populations, resettled Puebloan groups from New Mexico and European colonists, and rapidly changing economic and social arrangements among these groups, ultimately leading to Native American assimilation into Spanish Colonial culture (Peterson and Brown 1992).

Early European exploration was then followed by early Anglo-American settlers from 1820 to 1860 in the Panhandle and Plains (Hays et al. 1989), while Spanish forces controlled the Trans-Pecos until 1846 (Miller and Kenmotsu 2004:258-265). Though the Civil War (1860-1865) was an important period of political and social upheaval, there was only limited military action in West Texas. Settlement in the region increased after the Civil War following changes in the southern economy, population growth, immigration, the release of large numbers of men from military conscription, and the development of railroads. Regional drought and the Great Depression impacted the region heavily, with economic and ecological disaster provoking massive migration from West Texas, Oklahoma, and Kansas to California (Hays et al. 1989). While many West Texas counties remain sparsely populated, large scale ranching and vegetable farming are viable industries in the region and the oil industry has brought various economic booms.

\section{Previous Cultural Resources Investigations}

The lack of large-scale surveys and excavated sites in the region is the main reason that the archaeology of the project area is not well understood. However, the geomorphology of the project area also contributes to the deficit of archaeological information. The project area is in the arid Trans-Pecos region where water is limited to major waterways like the Pecos River. Multiple surveys have been 
conducted near the project area in association with new pipeline construction, some of which have recorded sites. However, none of these previous studies extend into the project area.

The THC Atlas (THC 2020) records were reviewed prior to determining the cultural resources potential areas along the Route. According to the Atlas, no archeological sites, cemeteries, historic properties, historical markers, NRHP properties or districts, State Antiquities Landmarks were mapped within 1000 feet $(305 \mathrm{~m})$ the project area. As such, the identification of areas with archeological potential was based on local physiographic conditions such as proximity to water and geologic resources (see Chapter 4). In addition, the Atlas review indicated that a limited number of previous cultural resources survey areas are mapped within 1000-ft (305-m) of the Route (Figure 5). Most of these surveys occurred near the northern end of the project, which consisted of linear pipeline survey areas sponsored by the Bureau of Land Management in 2014. The remaining few surveys were associated with an oil and gas pipeline crossing at Salt Creek and a previous Oncor transmission line project located at the southern end of the Route. The Atlas records indicated that no cultural resources sites were identified during any of the previous survey areas that overlap with the 1000-ft (305-m) search radius.
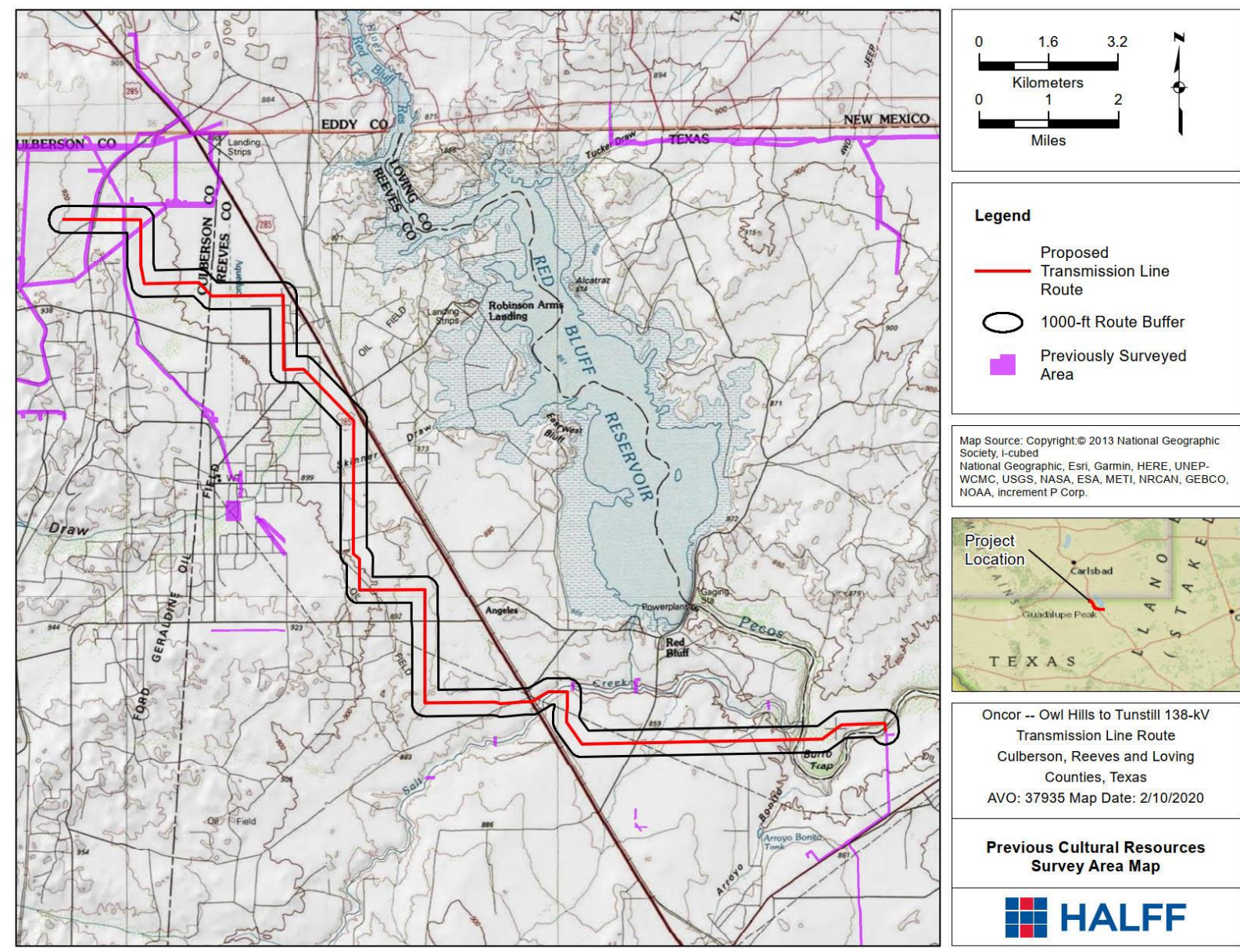

Figure 5: Previous cultural resources survey areas located in the project vicinity 


\section{Historic Map Review}

In addition to a review of previously recorded archeological sites and investigations in the project vicinity, a review of the following historic maps was conducted: 7.5-minute USGS Texas Topographic Quadrangles (USGS 2020b), 1931 and 1968 Orla, 1961 Orla SE, 1968 Red Bluff, 1973 Screw Bean Draw, and 1943 and 1967 historic aerial photography (NETR 2020). No historic structures were observed along the Route on any of the topographic or aerial maps reviewed.

The earliest available topographic maps for the project area show that two sections of the Atchison, Topeka \& Santa Fe (ATSF) Railway are crossed by the Route. The ATSF Railway crossings are located at the northern end of the Route just east of the existing Owl Hills substation, and just east of US 285. The northern most railroad crossing is depicted on the 1976 topographic map but is not present on the 1967 aerial. The railway section that parallels US 285 to the east shows up on the 1931 and 1968 topographic map and 1967 aerial, indicating it is historic in age (Figure 6).

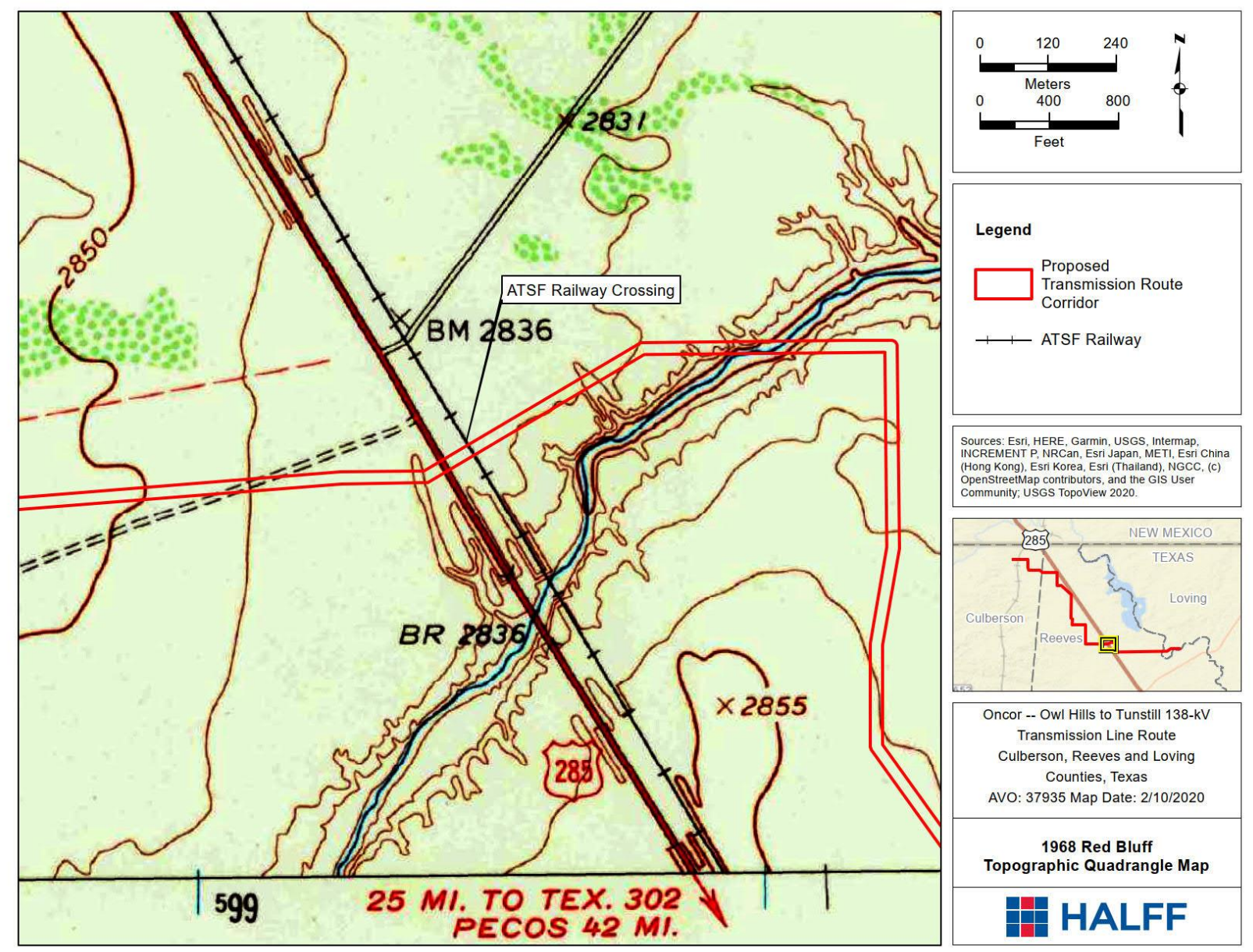

Figure 6: 1968 Red Bluff Topographic map showing ATSF Railway. 


\section{Research Design and Methodology}

\section{Research Design}

The Oncor Generic Research Design (PBS\&J 2008) calls for the project area to be classified into High Probability Areas (HPAs), Moderate Probability Areas (MPAs), and Low Probability Areas (LPAs) on the basis of the estimated likelihood for the occurrence of archaeological sites in the Trans-Pecos region. For prehistoric sites, this stratification is based on previously recorded site distributions, soils, geomorphology, topography, prior disturbances, and distance from permanent and intermittent water sources (i.e., creeks, rivers, and springs), which were identified prior to fieldwork. For historic sites, the mapped locations of structures and distance to roads are the main elements in identifying areas with resource potential.

In the Trans-Pecos, HPAs for prehistoric archaeological sites were defined as areas relatively close $(<500 \mathrm{~m})$ to water sources, specifically on shoulder slopes, on alluvial and colluvial fans, near upland edges adjacent to alluvial valleys, and near stream confluences. Holocene-age alluvial terraces and floodplains were also classified as HPAs since alluvial deposits offer the greatest preservation potential for buried and stratified prehistoric sites.

Prehistoric MPAs include areas that may contain archaeological remains, but their presence is considered to be less likely due to greater distances to water, strongly sloping areas, and/or eroded soils. These areas include upland margins, Pleistocene terraces, and gently sloping hillsides and toe slopes more than $500 \mathrm{~m}$ from streams. LPAs are those areas in which prehistoric archaeological sites are unlikely to be present because of steeply sloping topography, erosion, or modern development. Any prehistoric archaeological sites in these settings would not likely retain integrity.

Following these guidelines, the Owl Hills_-Tunstill Route was classified as follows: HPAs:

- within the Pecos River valley (prehistoric),

- the uplands east and west of the Pecos River (prehistoric),

- the ephemeral drainages between the Pecos River and Salt Creek (prehistoric),

- the terraces east and west of Salt Creek (prehistoric),

- the opposing banks of Skinner Draw (prehistoric), and

- the ATSF Railway (historic)

The MPAs for prehistoric and historic site were identified as the remainder of the Route and no LPAs were identified during background research. 


\section{Methodology}

Field personnel walked the proposed Route along two transects each approximately 5 to $10 \mathrm{~m}$ (16 to 33 feet) on either side of the proposed centerline, within the 70-foot (21-m) wide corridor. Shovel tests were excavated within $500 \mathrm{~m}$ of drainages regardless of ground visibility. Field personnel made notes about the ground exposure, soil types, hydrology, and disturbed areas where subsoil was exposed. As outlined in the Oncor Generic Research Design (PBS\&J 2008), shovel tests averaged 20 $\mathrm{cm}$ in diameter and were excavated in 10-cm (4-inch) levels. Sandy soils were inspected visually and screened through a 0.25 -inch wire mesh to determine if cultural materials were present. Dense soils with high clay content were troweled or hand-sorted and visually inspected. Soils were described based on color and texture, and the Munsell Soil Color Chart was used to identify the specific soil colors in each test (Munsell 2009). Shovel test and site locations were recorded using handheld GPS receivers and photographs were taken with a digital camera. Since no artifacts were found in subsurface contexts and no temporally diagnostic artifacts were noted on the surface, all artifacts were analyzed in the field and left where they were found.

Upon identification of archaeological sites, the boundaries were delineated based on the distribution of artifacts and features and arbitrary shovel tests were placed within site boundaries near artifact concentrations to test for subsurface deposits and site integrity. Given the high level of ground visibility and relative potential for buried soil deposits, site boundaries were delineated by the surficial extent of artifacts or surface features. A representative artifact assemblage from each site was photographed and respective site plan maps were sketched in the field. A temporary field designation was assigned to each site and TexSite forms were completed and submitted to TARL for permanent trinomial assignment. 


\section{RESUlts}

The entire Owl Hills-Tunstill Transmission Line Route underwent pedestrian survey using two transects placed 5 to $10 \mathrm{~m}$ ( 16 to $33 \mathrm{ft}$ ) on either side of the proposed centerline in the identified MPAs and intensive survey with shovel tests placed at 30- to 50-m intervals within portions of the Route corridor designated as HPAs. The general ground cover and vegetation observed along the Route were typical of the Trans-Pecos region, with 3- to 4- $\mathrm{ft}$ tall mesquite trees observed in various densities, and low-lying creosote bush, yucca and cactus. Ground visibility was a consistent 70 to 90 percent in much of the Route (Figure 7), with decreases to between 20 to 40 percent along low-lying areas where water tends to collect during sporadic rainfall events (Figure 8). The Route intersects with numerous gravel lease roads and existing utility and pipeline corridors constructed as a result of the ongoing oil and gas industry in the region (Figure 9).

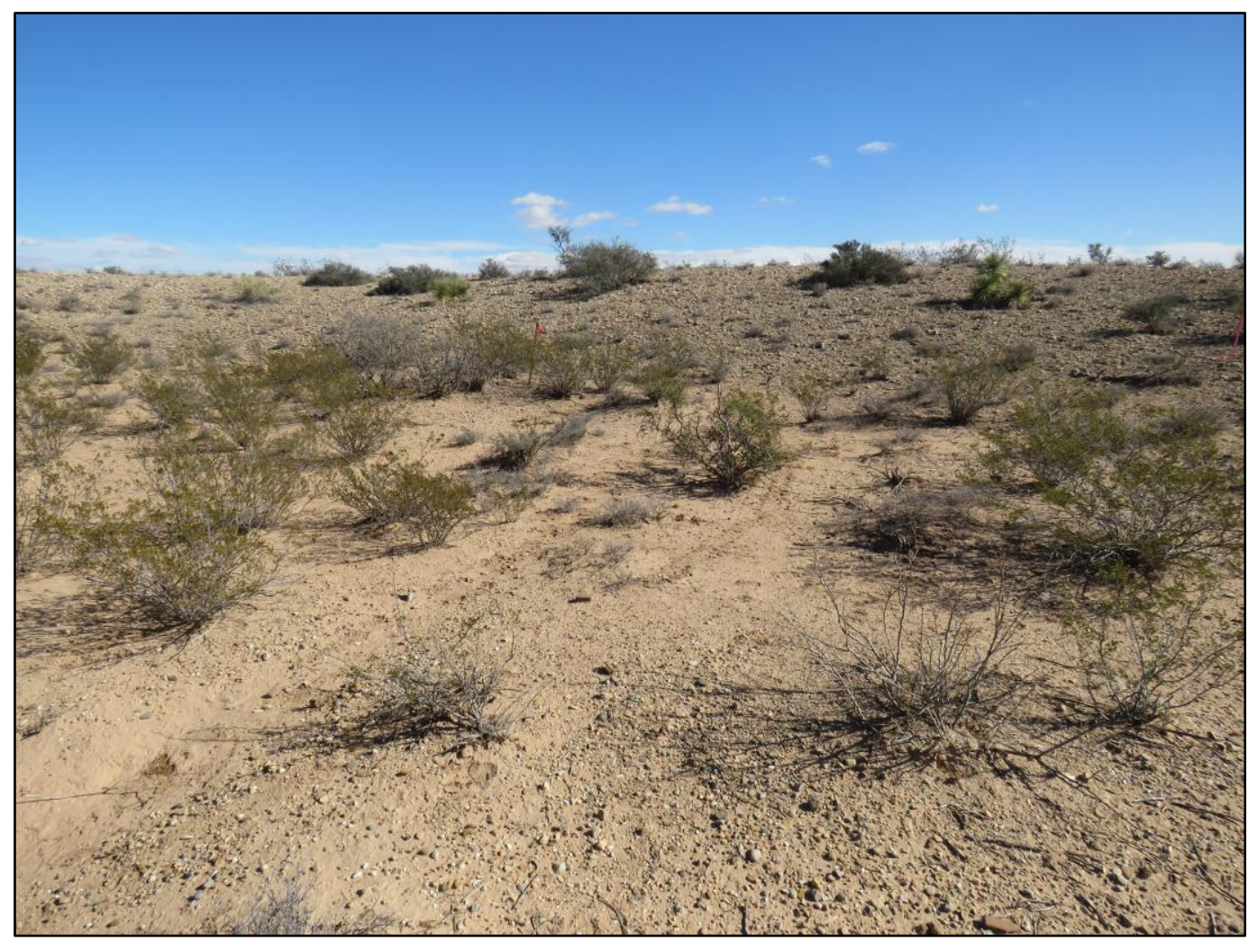

Figure 7: Common degree of ground exposure along the Route, looking east. 


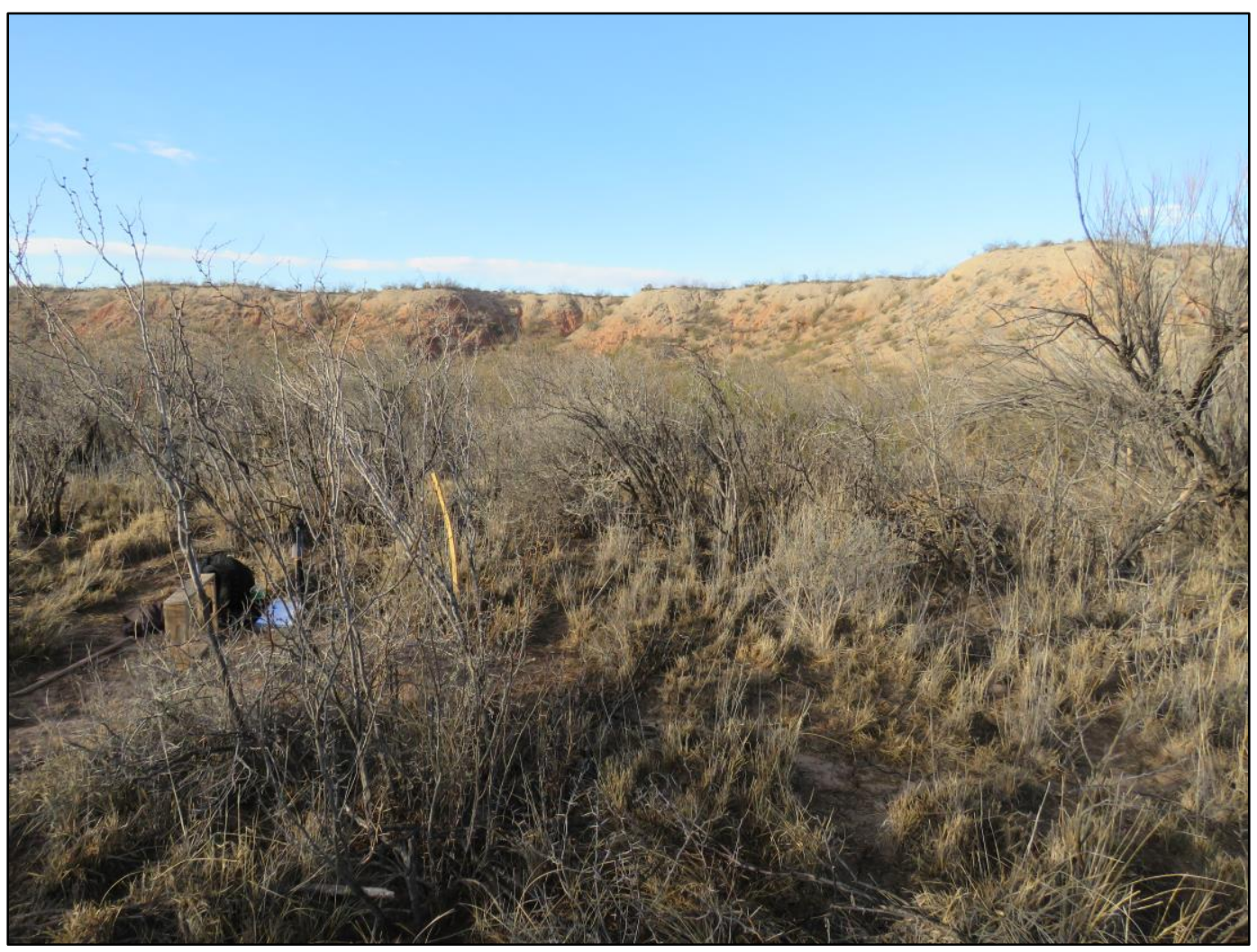

Figure 8: Example of dense ground cover in low-lying area, looking south

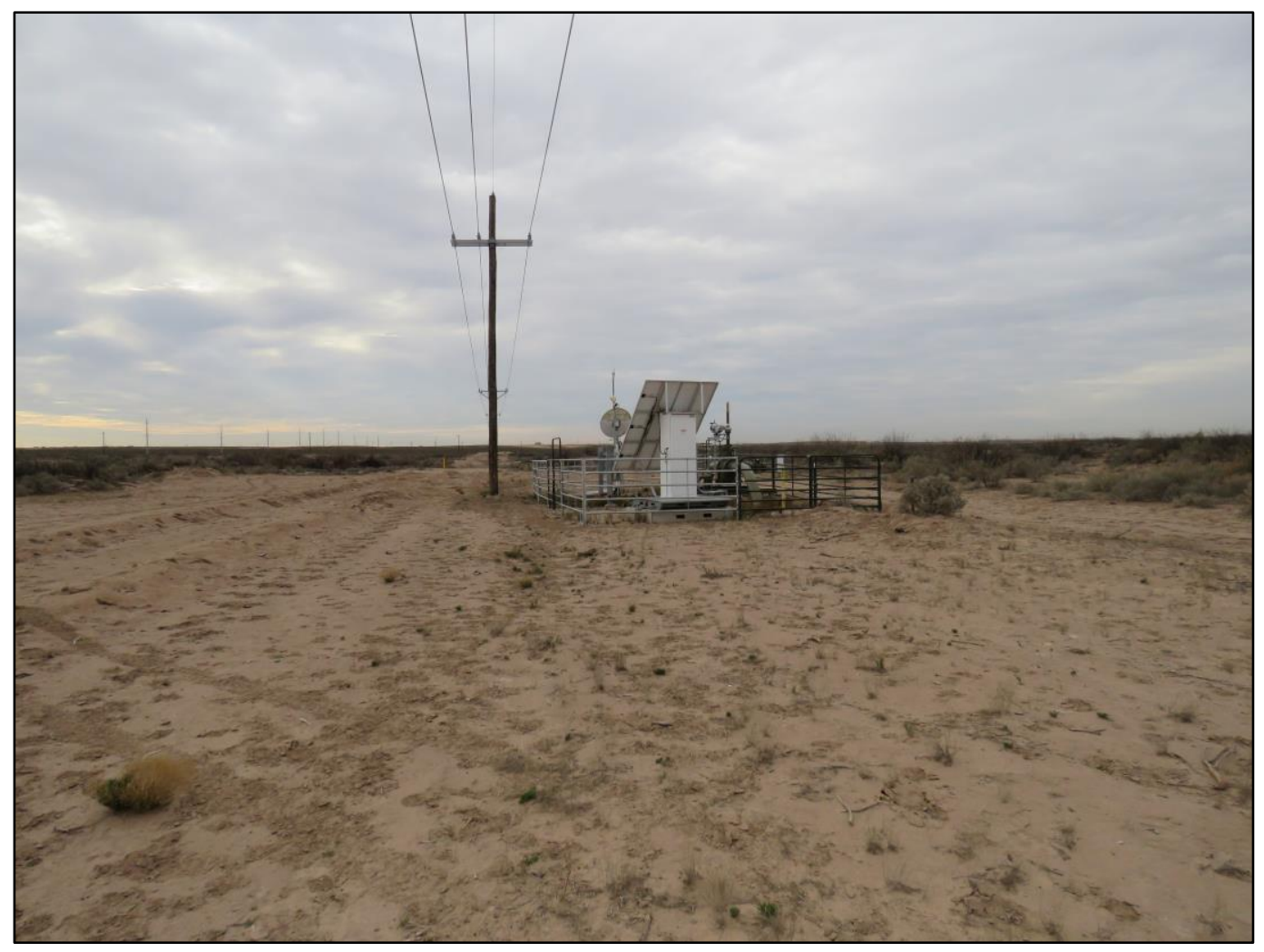

Figure 9: Example of pipeline corridor and telephone utility crossing the Route, looking south. 
The southern end of the Route begins at the existing Tunstill POD and traverses the alluvial terraces and floodplain of the Pecos River, which were treated as one continuous HPA. This stretch of Route extends northward from the Tunstill POD across the Pecos River channel, then heads west and southwest through the meander bend deposits, across the second Pecos River crossing, and atop the gravelly valley rim. This $2.9-\mathrm{km}$ (1.8-mile) long HPA section was investigated with 62 shovel tests placed at intervals ranging from 30 to $50 \mathrm{~m}$ (Figure 10). The soils encountered in the shovel tests dug on the lower terraces of the valley floor were a consistent reddish brown (5YR 5/4) fine sandy loam with little to no change in color or structure down to $80 \mathrm{~cm}$ below the surface (cmbs). The soils for the most part contained few to no gravels, were culturally sterile and had a composition consistent with the Monahoans-Pajarito complex (see Table 1).

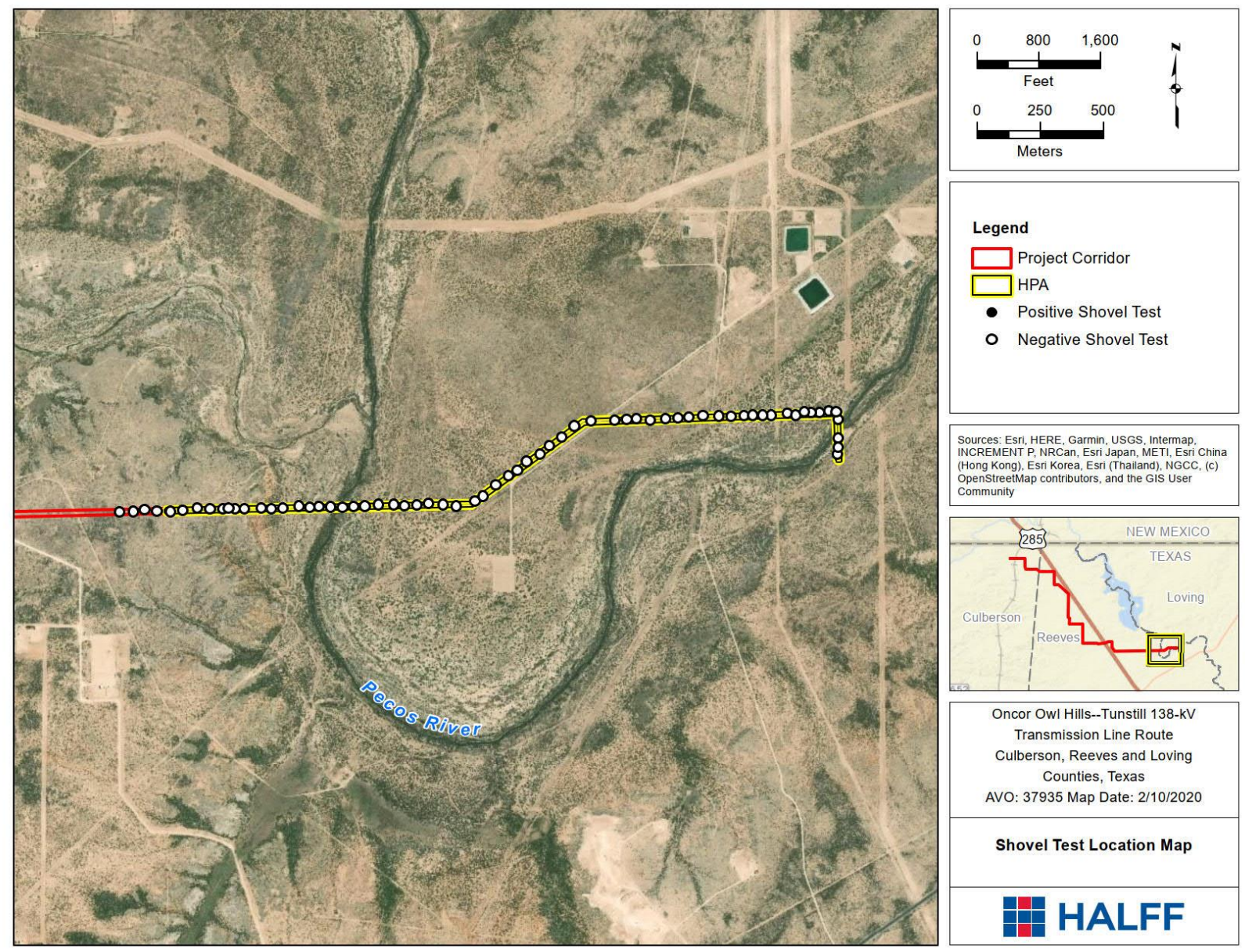

Figure 10: Shovel test locations along the Pecos River HPA.

Conversely, the upper Pecos River terraces contained a dense gravelly loam at the surface and shallow bedrock around 25-30 cmbs, which aligns with the soil composition for the Delnorte-Chilicotal association. Amongst the abundant gravels occurring along the gently sloping upland are occasional pieces with a crystalline structure suitable for use as tool stone resources, which are generally uncommon throughout region. The utilization (and paucity) of this workable chert material by prehistoric hunter-gatherer groups is evidenced by the findings at site 41RV208, which contained lithic 
debitage, expedient stone tools and exhausted cores produced from locally occurring gravel- and cobble-sized pieces of chert. This site was discovered near the western end of the HPA and is discussed in detail later in the chapter.

A series of HPAs were identified for the ephemeral drainages and main channel of Salt Creek, which is the only other main waterway along the Route. One HPA is located just south of a section of erosional drainages that empty into the Salt Creek channel approximately $750 \mathrm{~m}$ to the northeast. This HPA section measured roughly 820 -m long and was investigated with nine negative shovel tests spaced at approximately $50 \mathrm{~m}$ (Figure 11) and containing a brown (7.5YR 5/4) very gravelly loam over cemented gypsum gravels at around $40 \mathrm{cmbs}$. This HPA section was heavily eroded with dense gravels and gypsum bedrock surface exposures observed along the drainage slopes. The next HPA affiliated with the Salt Creek drainage basin was identified along an ephemeral swale with relatively dense vegetative cover. This 620 -m long HPA was investigated with eleven shovel tests dug at roughly 50$\mathrm{m}$ intervals (Figure 12), all of which were negative and contained brown (10YR 5/4) and compact calcareous clay loam indicative of older low velocity flood sediment deposits.
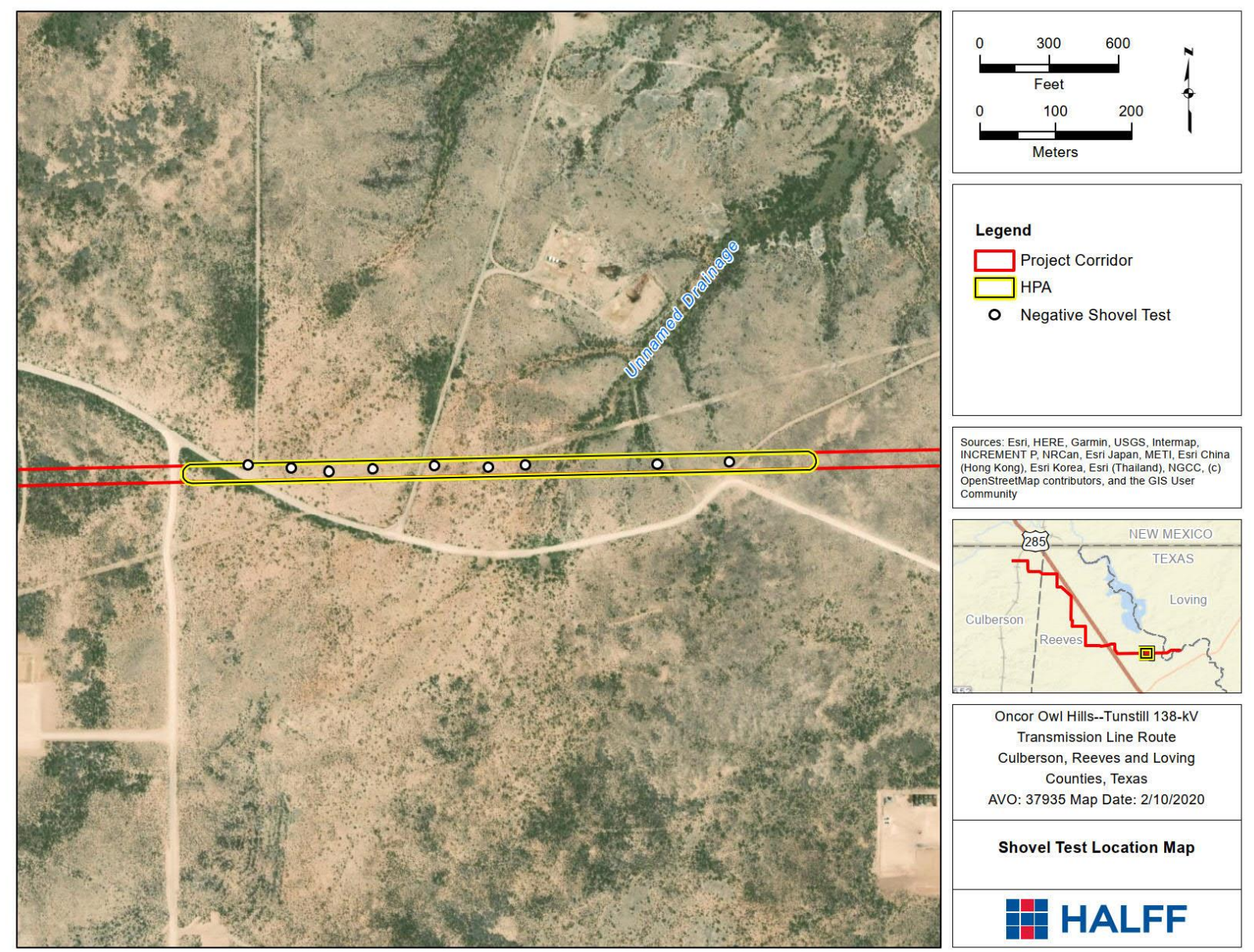

Figure 11: Shovel tests placed along the Salt Creek drainages HP A. 

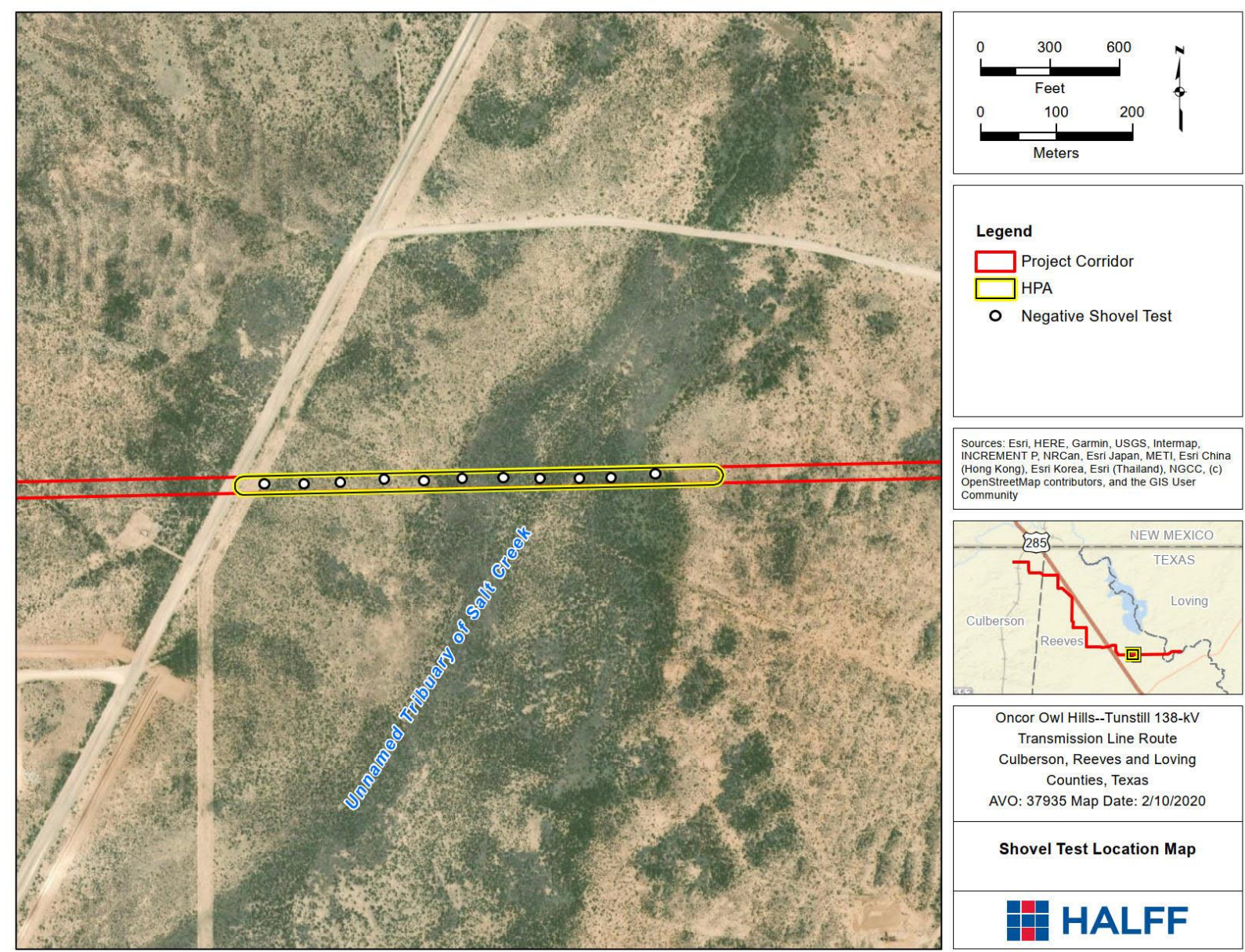

Figure 12: Shovel tests placed along the unnamed tributary of Salt Creek HPA.

The HPA at Salt Creek was observed to be heavily disturbed and eroded along its eastern banks from an existing pipeline and utility corridor with cleared vegetation extending into the Route corridor. The Salt Creek HPA spans approximately $720 \mathrm{~m}$ and was investigated with nine shovel tests arbitrarily placed to avoid disturbed areas and erosional cuts (Figure 13). Along the west side of the creek, a cleared pipeline corridor parallels the Route to the north, causing heavy erosion in adjacent areas. A sparse surface scatter of cultural materials was observed in this area, which are associated with the newly recorded site 41RV209 (covered in detail later in the chapter). The soils consisted of a very compact brown (10YR 5/4) clay sand that was culturally sterile. The lack of vegetative cover on the west side of Salt Creek, along with ongoing commercial activity, is contributing to the actively eroding banks of Salt Creek.

The portions of the APE adjacent to the northeast and southwest of the historic ATSF railroad corridor have been heavily disturbed by commercial activity. In addition, the former railway line and berm have been completely levelled within the APE and further down the line outside of the APE. Due to the exposed ground surface and disturbed pipeline corridors on either side of the railway, no shovel tests were excavated. The existing conditions documented for the historic railway in the APE are detailed below (see Site 41RV213 section). 

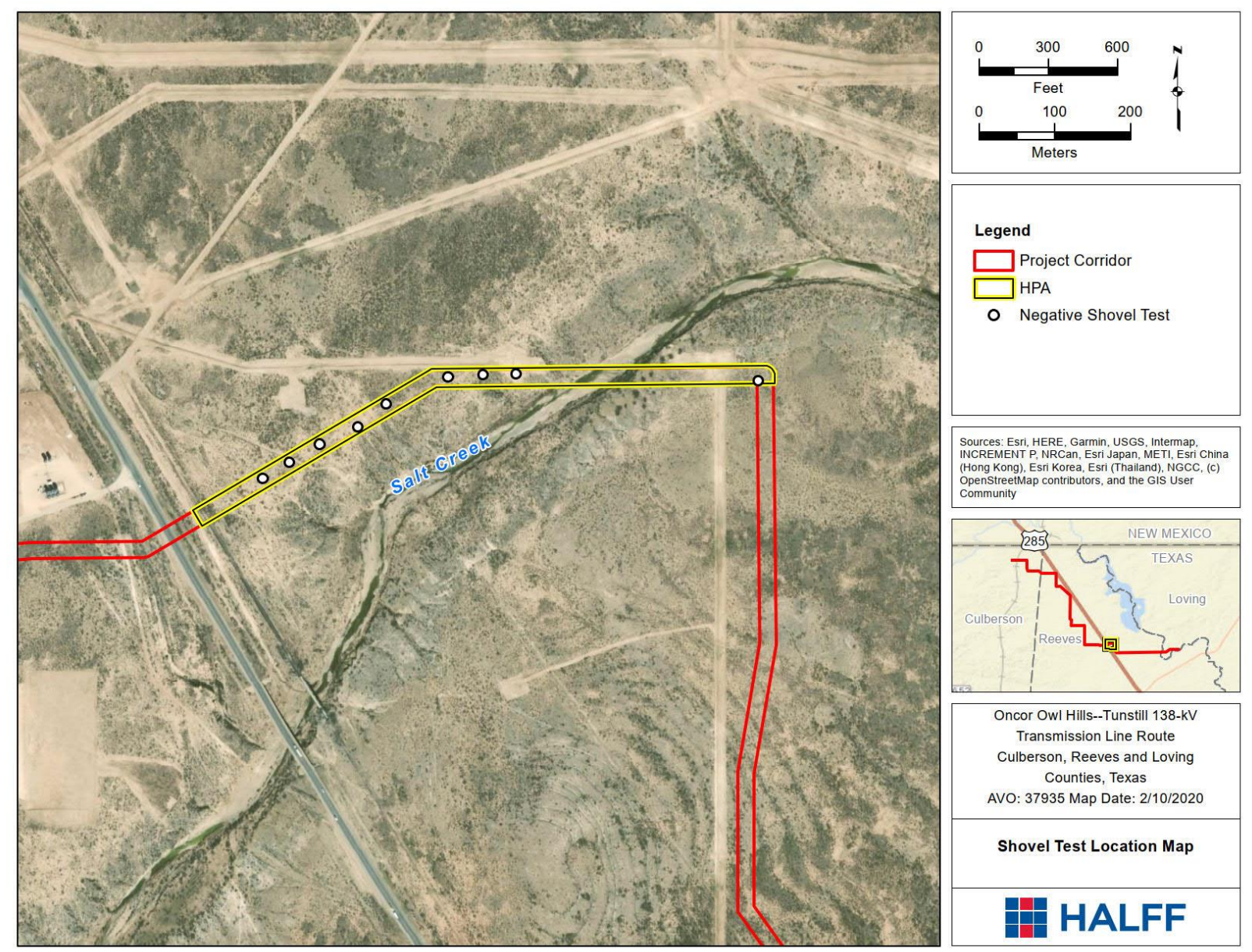

Figure 13: Shovel tests placed along the Salt Creek/ATSF HPA.

The HPA at Skinner Draw consisted of an ephemeral drainage and was investigated with five shovel tests, all of which contained a compact brown (10YR 5/3) clay loam that was culturally sterile (Figure 14). The remainder of the Route contained areas treated as MPAs due to the relative distance from perennial water sources, a low potential for buried soil deposits and limited vegetative cover allowing for consistent visibility of the ground surface. The MPAs were located primarily along sections of the Route west of US 285 in hydrologically and topographically featureless areas containing mostly gravelly surfaces and some ground disturbance in sections that paralleled and intersected utility corridors and roadways. Figures 15 through 22 provide photographic examples of the common terrain observed in the MPAs (Figures 15 and 17) and HPAs (Figures 18 through 22). 

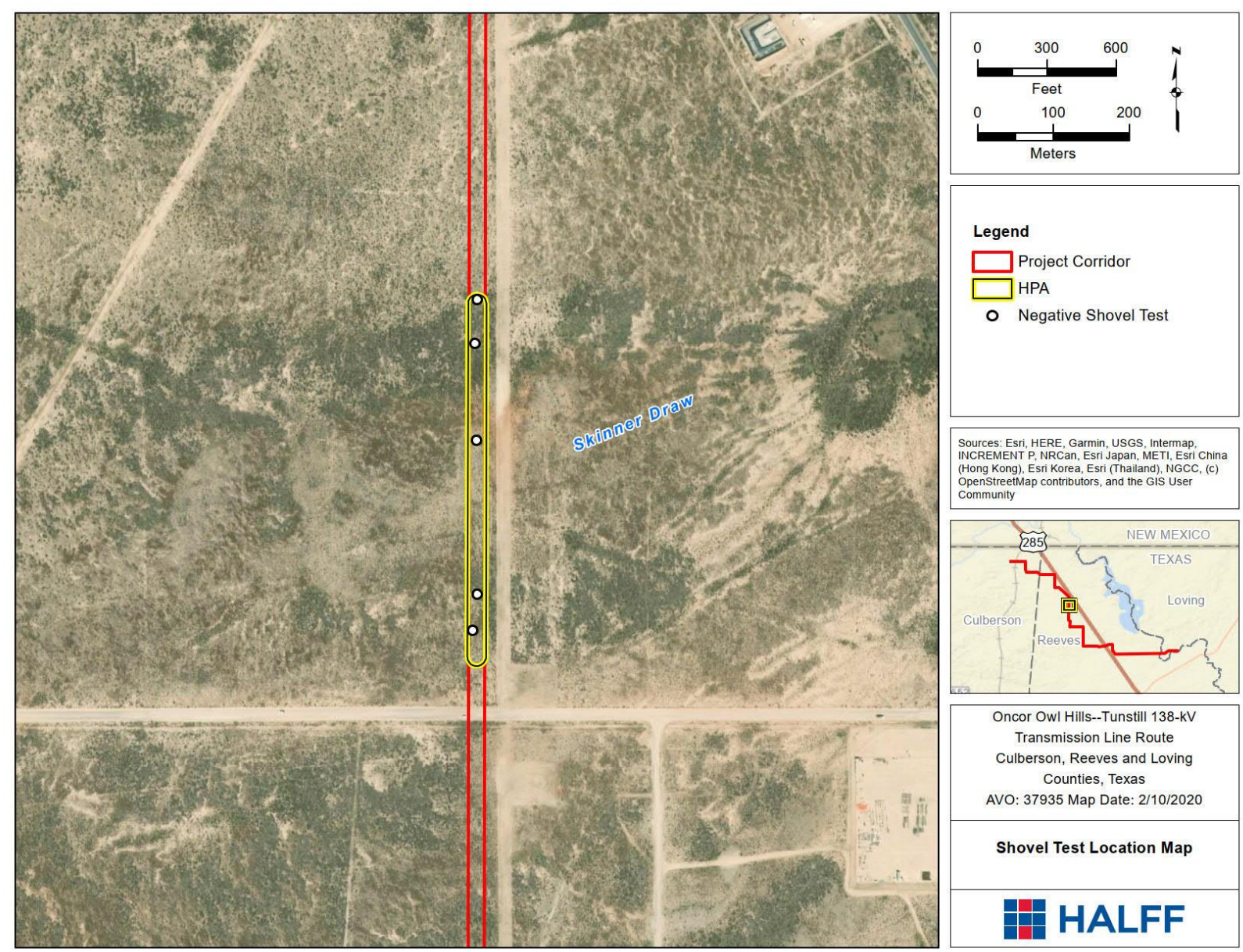

Figure 14: Shovel tests locations at the Skinner Draw HPA 


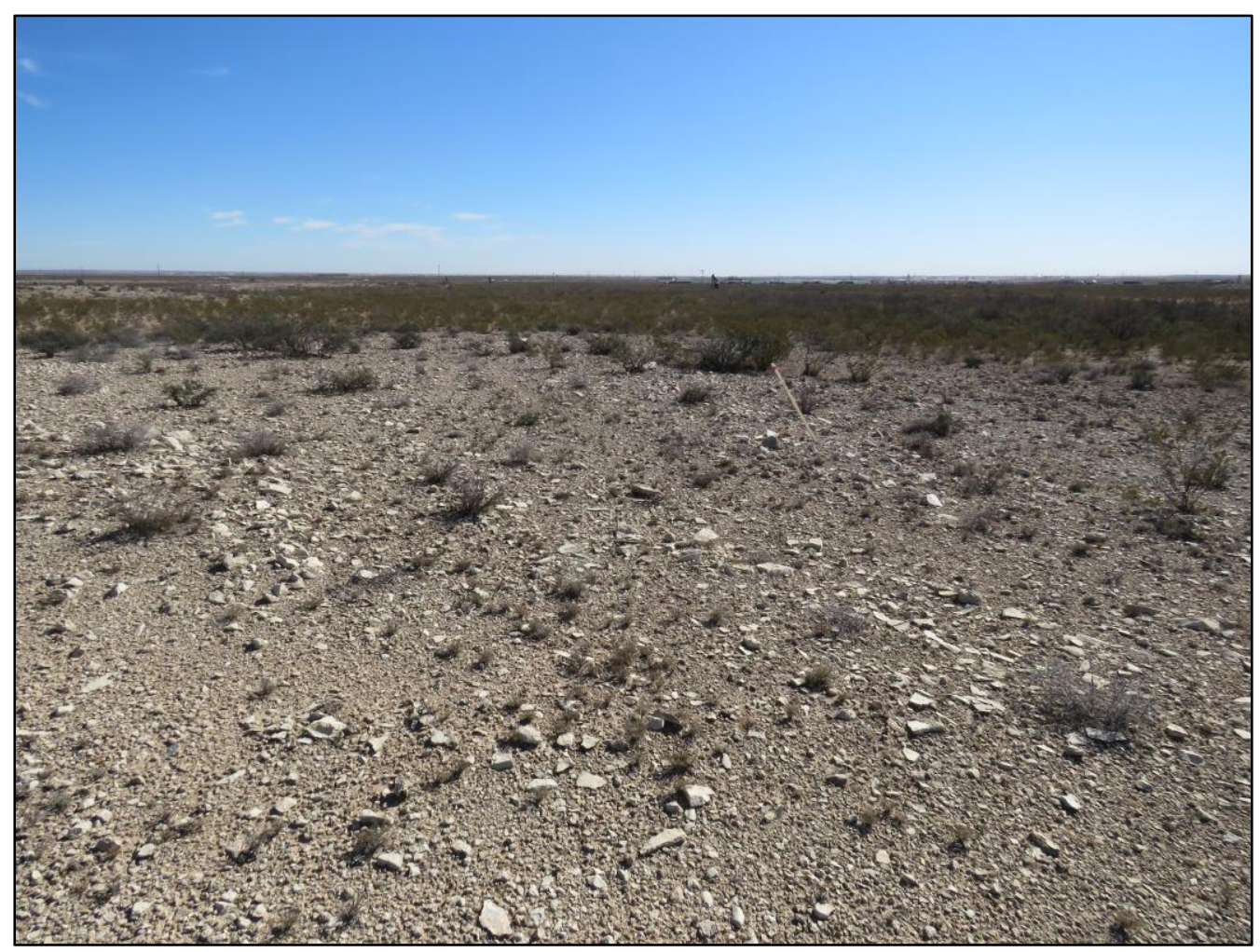

Figure 15: Common gravelly terrain and ground cover along MPAs.

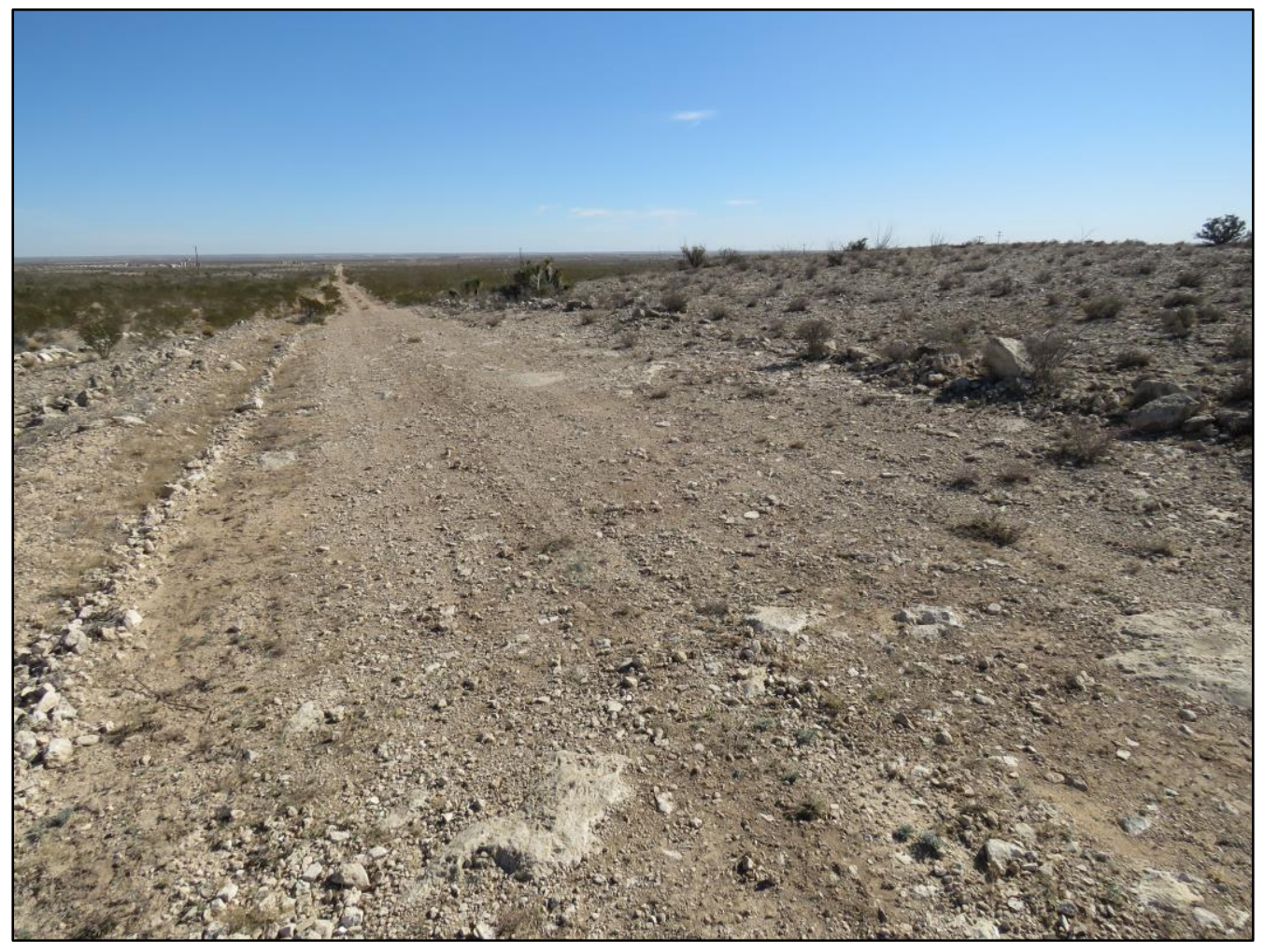

Figure 16: Common terrain and ground disturbance along MPAs. 


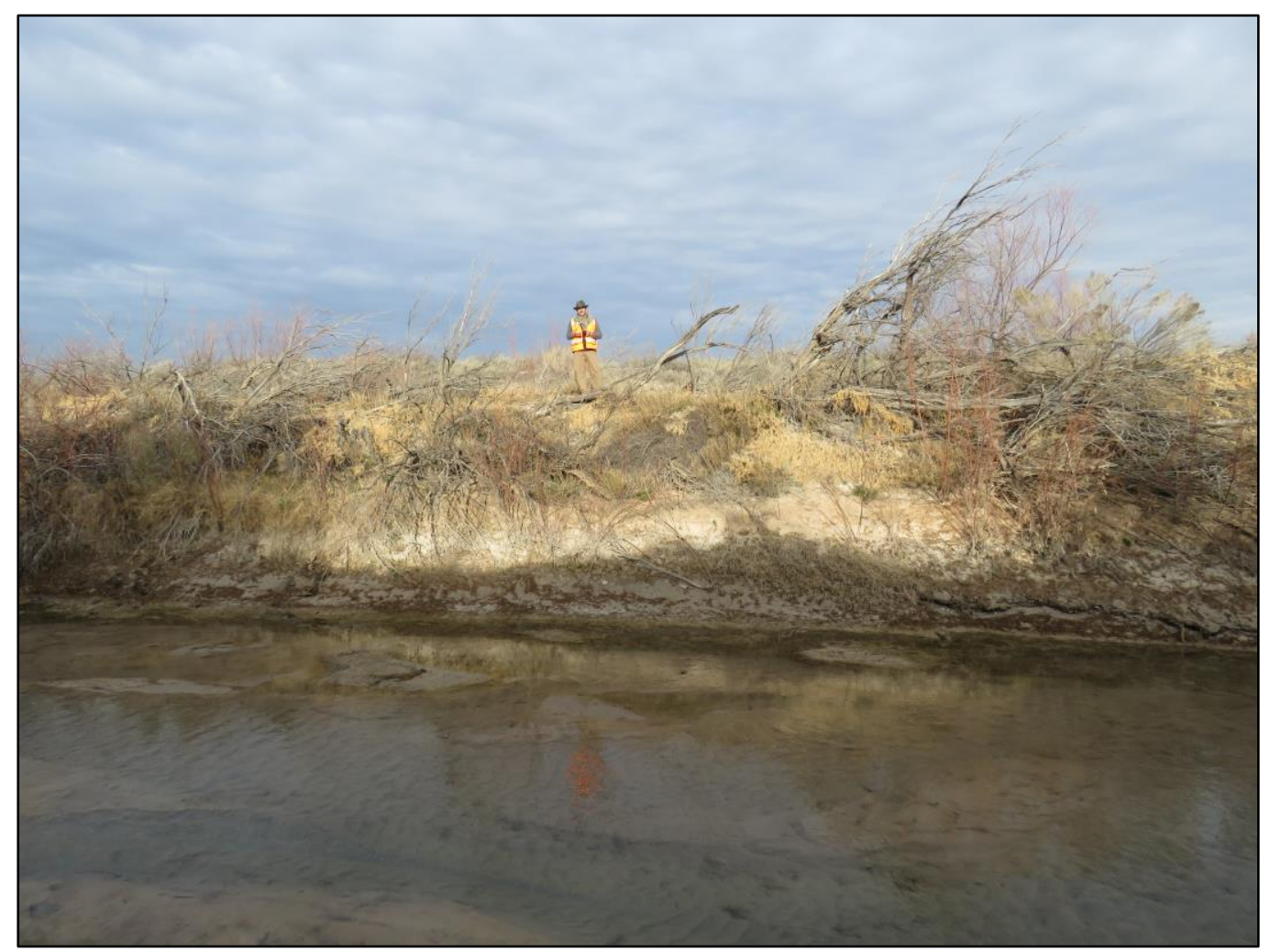

Figure 17: Pecos River HP A cutbank profile, facing north.

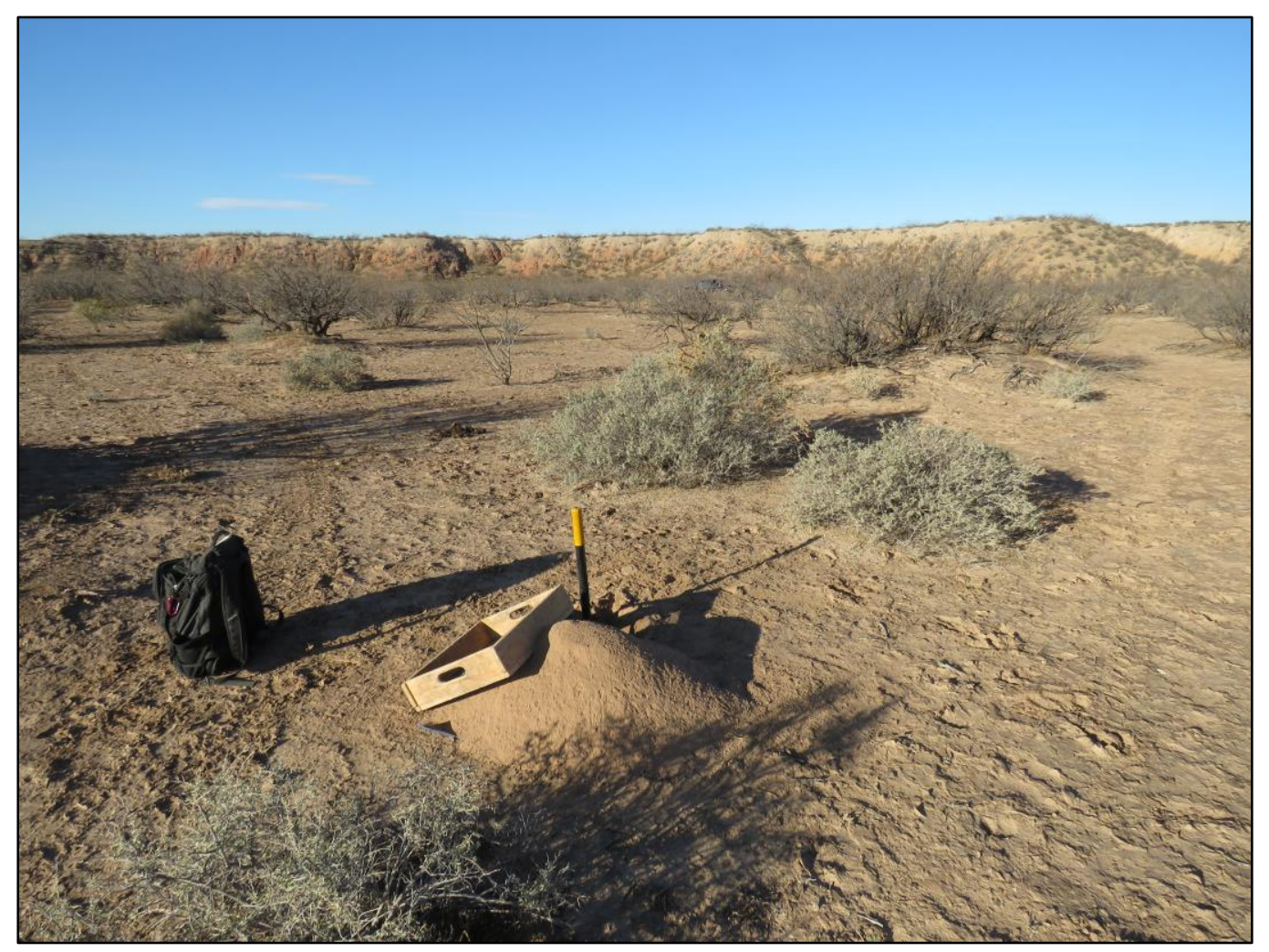

Figure 18: Fine sandy and culturally sterile soil encountered within the Pecos River V alley. 
Intensive Archeological Survey of the

Owl Hills_-Tunstill 138-kV Transmission Line Route

\section{曲 HALFF}

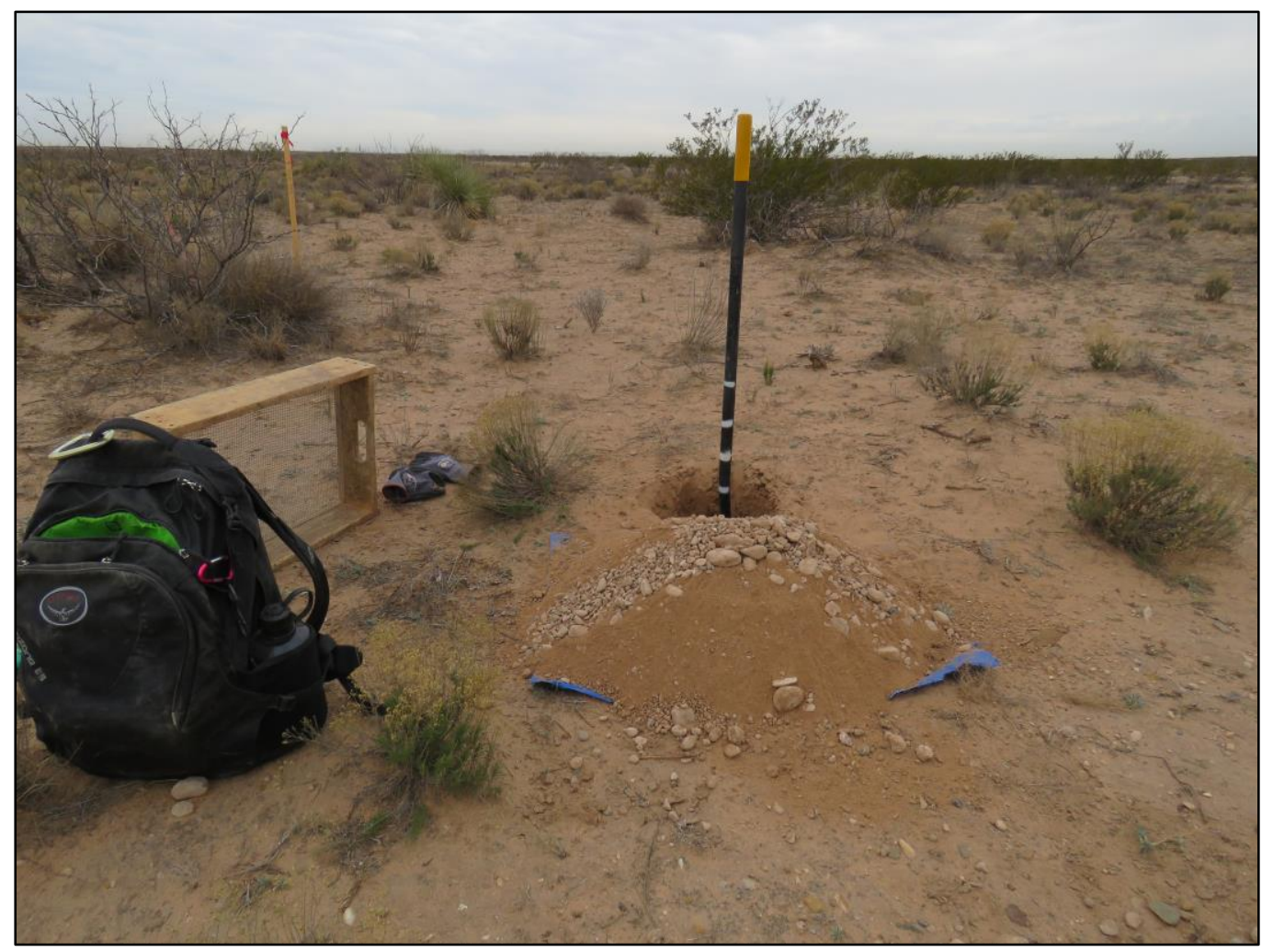

Figure 19: Common fine sandy soils with shallow gravel deposit in upland areas, looking west.

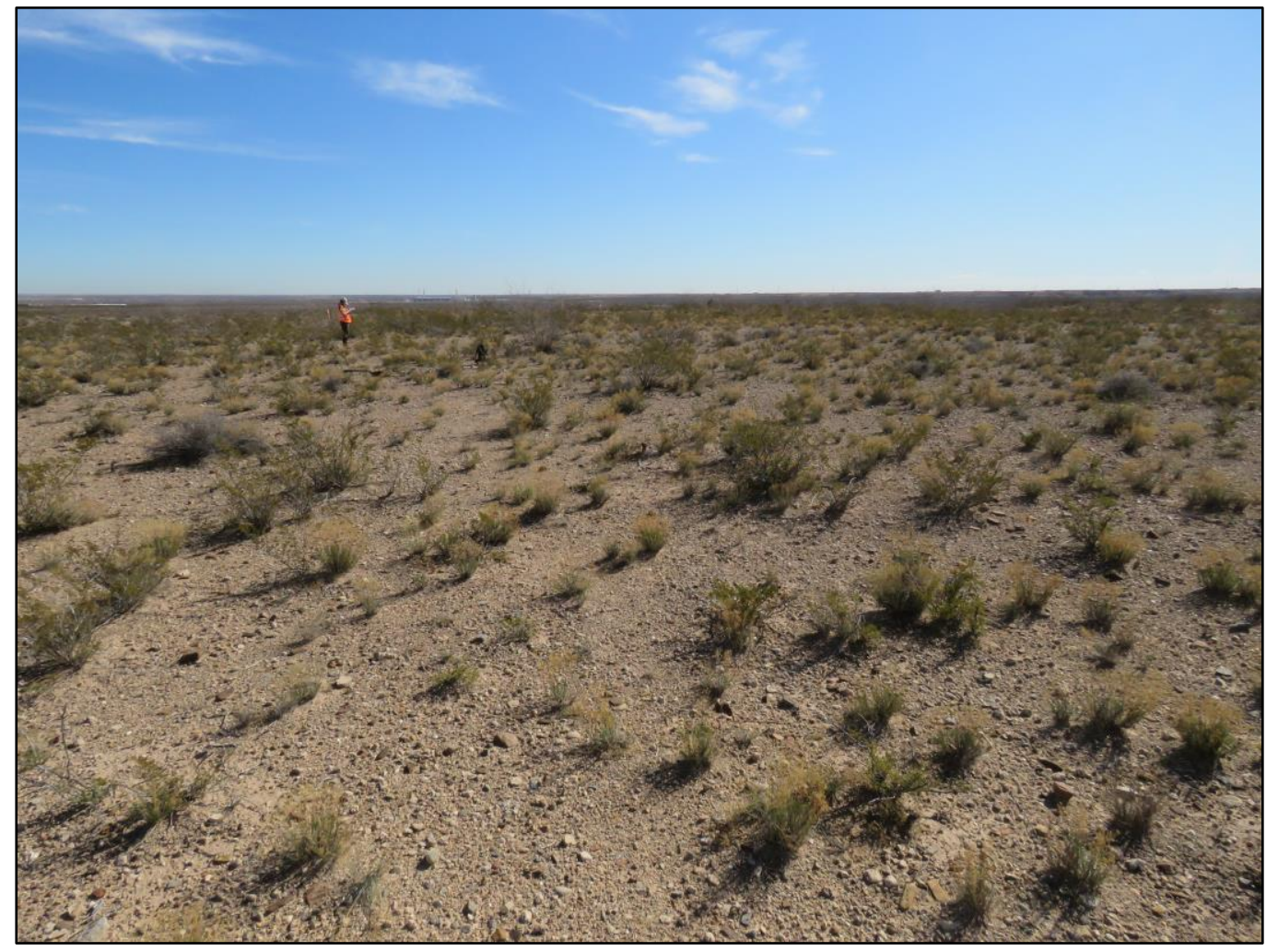

Figure 20: Typical view of gravelly upland west of the Pecos River V alley, looking west. 
Intensive Archeological Survey of the

Owl Hills_-Tunstill 138-kV Transmission Line Route

\section{曲 HALFF}

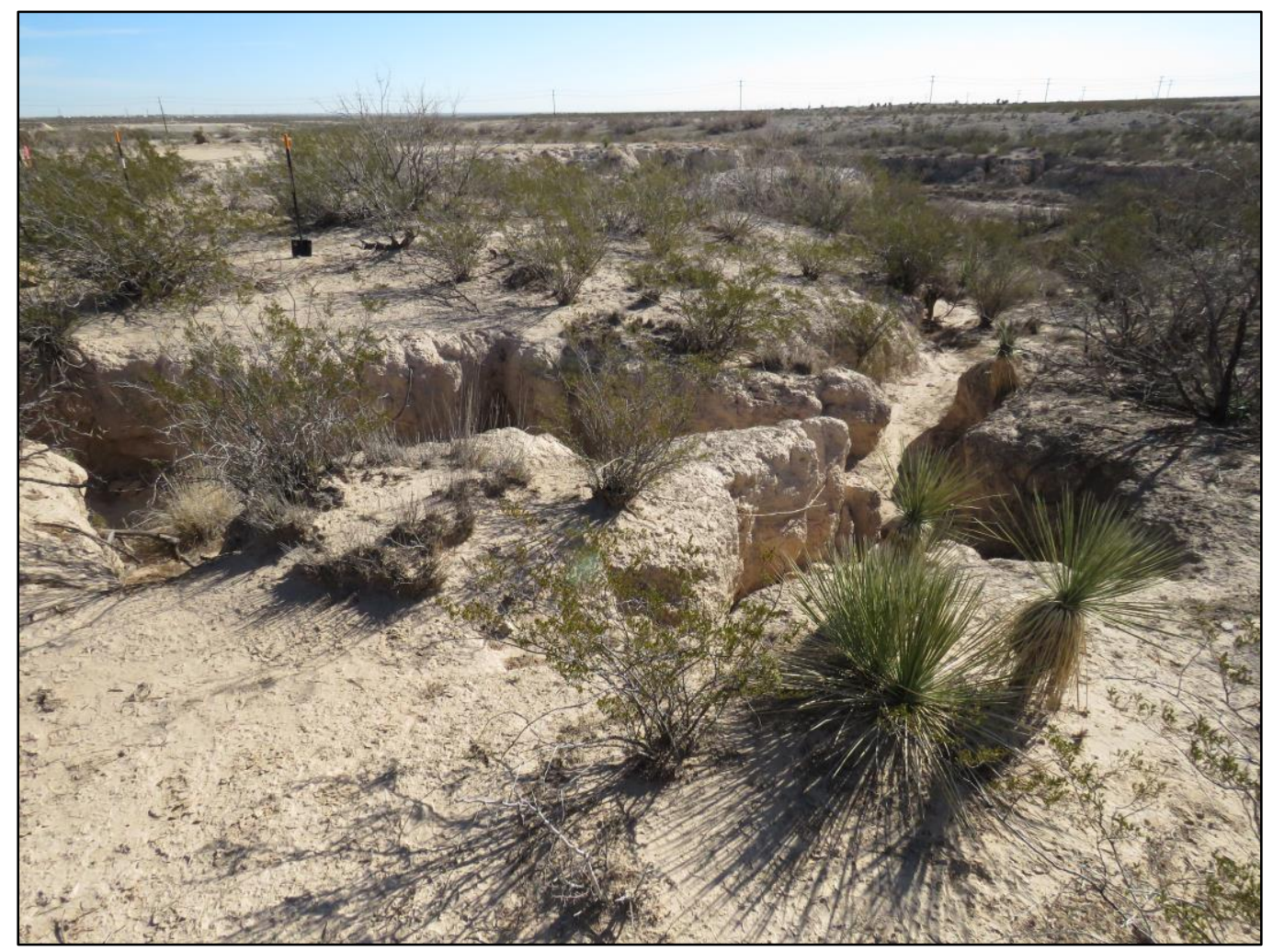

Figure 21: Heavily eroded surface along west bank of Salt Creek, looking southeast.

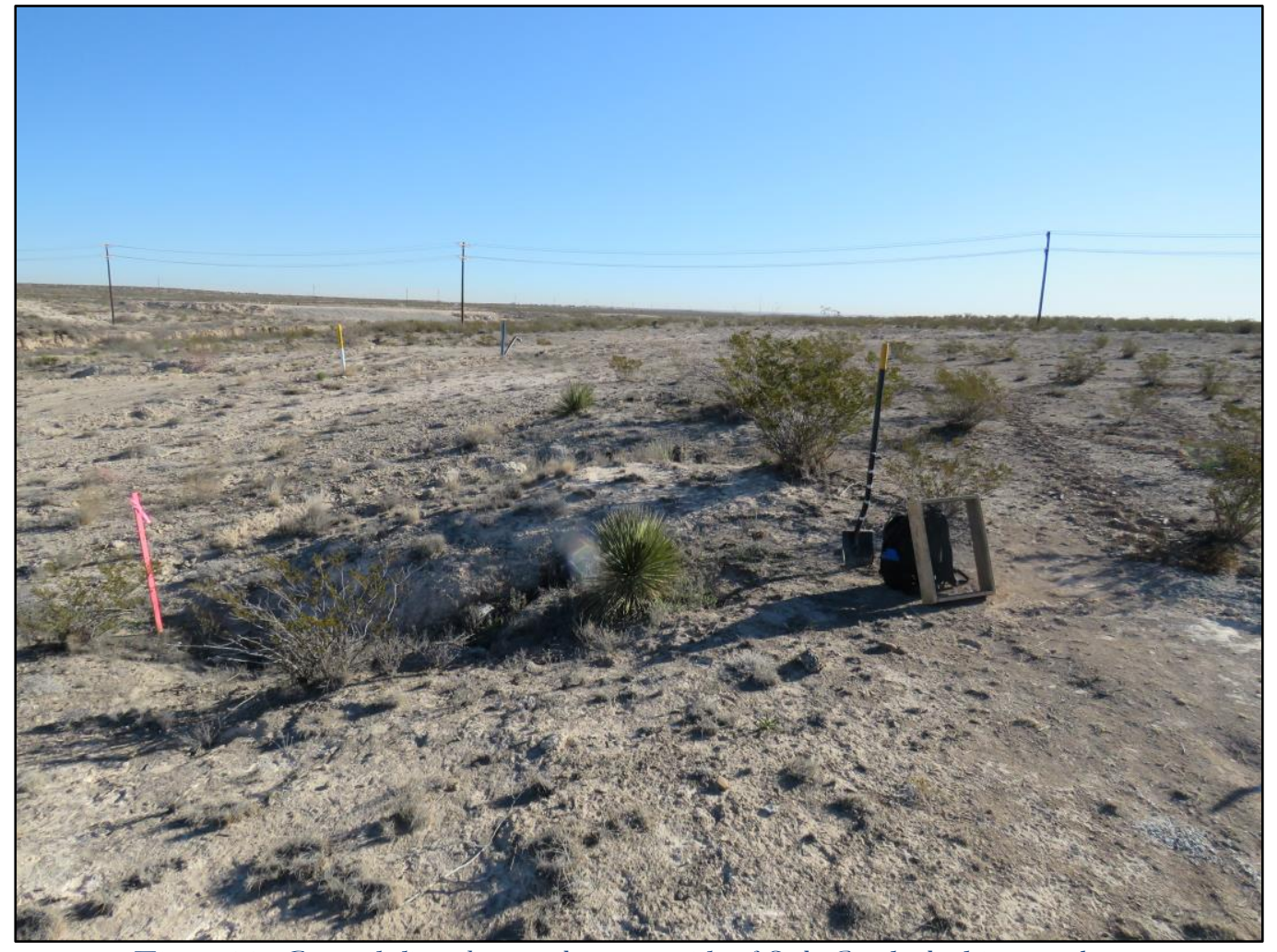

Figure 22: Ground disturbance along east side of Salt Creek, looking northeast. 


\section{Archeological Sites Documented}

The archeological field survey resulted in the identification and recording of two prehistoric-age sites (41RV208 and 41RV209), and one historic-age site (41RV213). Site 41RV208 is located near the western end of the Pecos River HPA and sites 41RV209 and 41RV213 are in the western portions of the Salt Creek and ATSF HPA.

$\underline{41 \mathrm{RV} 208}$

Site 41RV208 consists of a prehistoric occupation situated on the western rim of the Pecos River valley (Figure 23). The site was discovered during the intensive survey of the Pecos River HPA and delineated based on the horizontal distribution of artifacts visible on the surface, and the boundaries of the proposed transmission line corridor. Ground visibility at the site was around 90 percent due to sparse creosote and scrub brush and the ground surface along the gently sloping topography was eroded. The soils were a very gravelly loam over bedrock at around $25 \mathrm{cmbs}$. The site is bounded by ephemeral erosional drainages to the east and west, and covers an area measuring roughly $80 \mathrm{~m}$ eastwest by $30 \mathrm{~m}$ north-south, although the site likely extends beyond the northern and southern extents of the Route (Figure 24).

\section{Site location redacted}

Figure 23: Site location map for 41RV208. 


\section{Site location redacted}

Figure 24: Plan map for site 41RV208.

All of the artifacts at site 41RV208 were observed on the surface and include 12 lithic debitage, 6 flake tools, 6 cores, 2 groundstone fragments and approximately 40 fire cracked rocks (FCR) (Figures 2528). A semi-circular cluster of FCR was found on the surface measuring roughly 1 meter in diameter (see Figure 28). A shovel test placed in the northeast corner of the FCR feature revealed that the deposit did not extend below $4 \mathrm{~cm}$ and no charcoal, soil staining or cultural materials was observed (Figure 29). The shallow and unstratified nature of the thermal feature suggests ephemeral use during brief occupation at the site, which may have been centered around procurement of local gravels for tool manufacture. Photographs of site 41RV208 are provided in Figures 30 and 32.

The paucity of workable crystalline stone material in the surrounding region is reflected in the presence of expedient tools (i.e., edge-modified flake tools) and exhausted cores produced from the limited available chert and quartzite gravels at the site. The location of the site atop the Pecos River valley rim also suggests the procurement of local biotic resources drawn to the broad valley floor and river channel. However, due to the surficial nature of the site, and lack of diagnostic artifacts and features that could yield significant information about prehistoric lifeways or environments, site 41RV208 is recommended ineligible for NRHP inclusion in the surveyed area and no further work is warranted for the proposed project. 


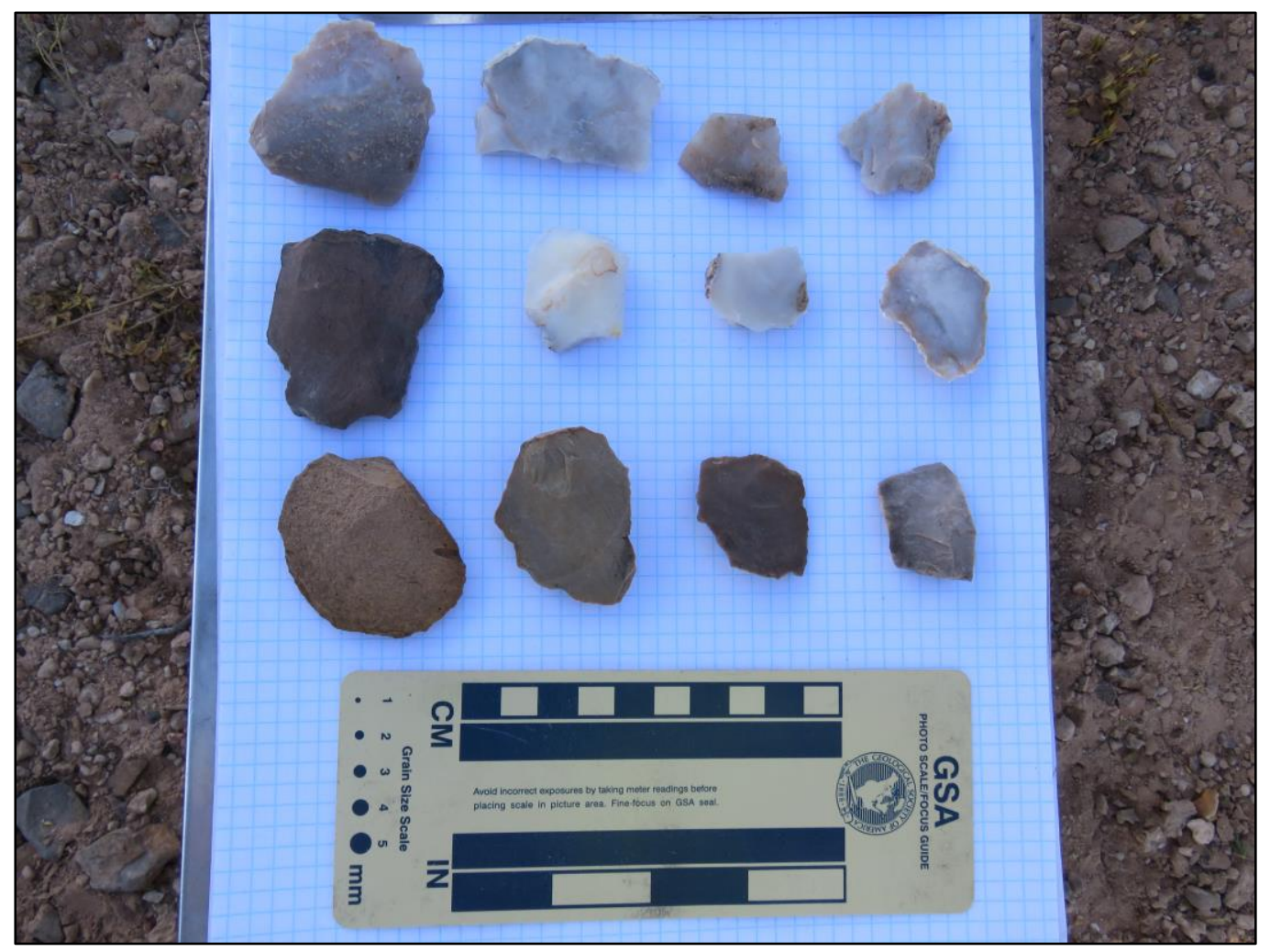

Figure 25: Lithic debitage assemblage from site 41RV208.

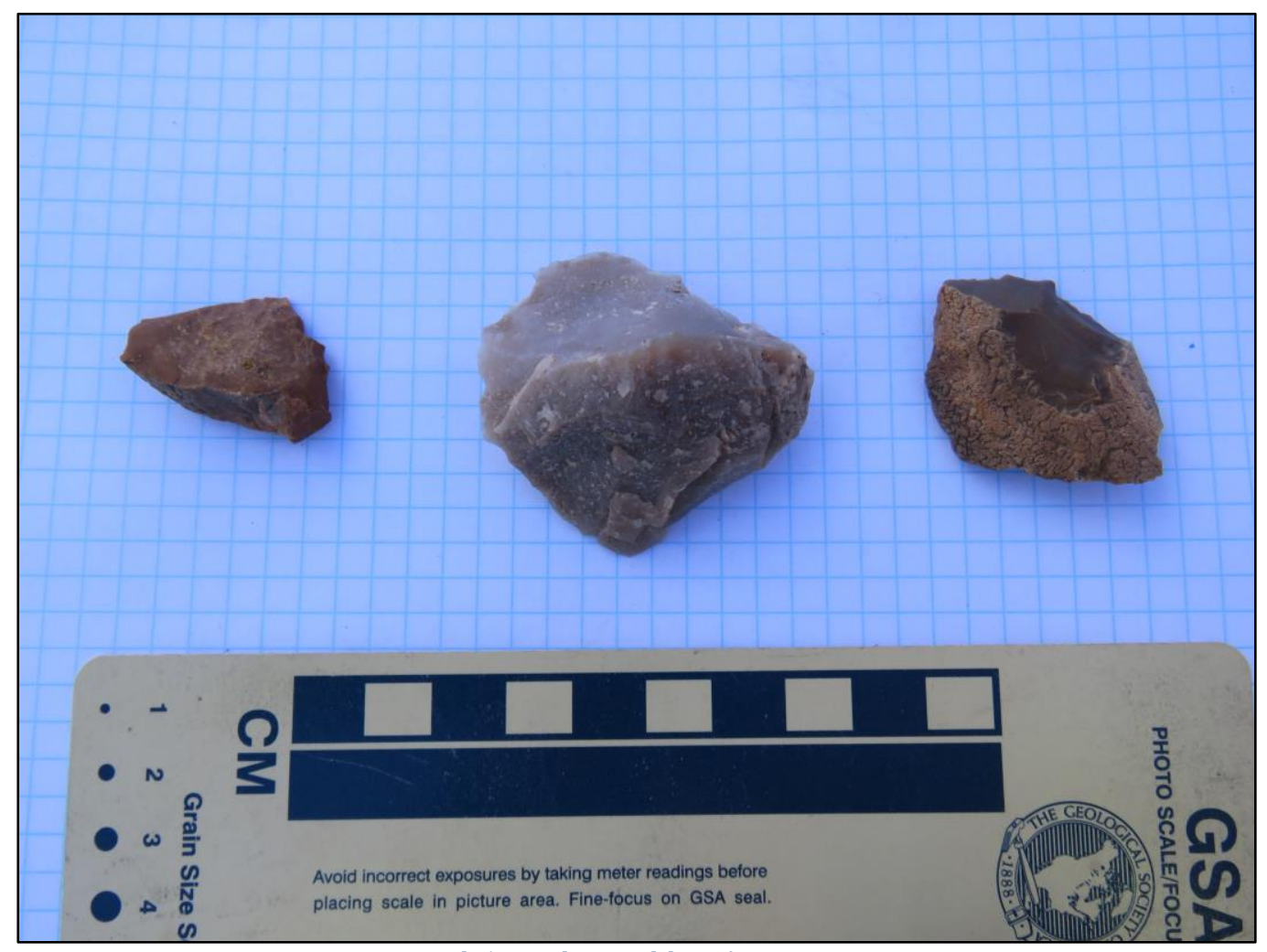

Figure 26: Flake tool assemblage from site 41RV 208. 
Intensive Archeological Survey of the

Owl Hills-Tunstill 138-kV Transmission Line Route

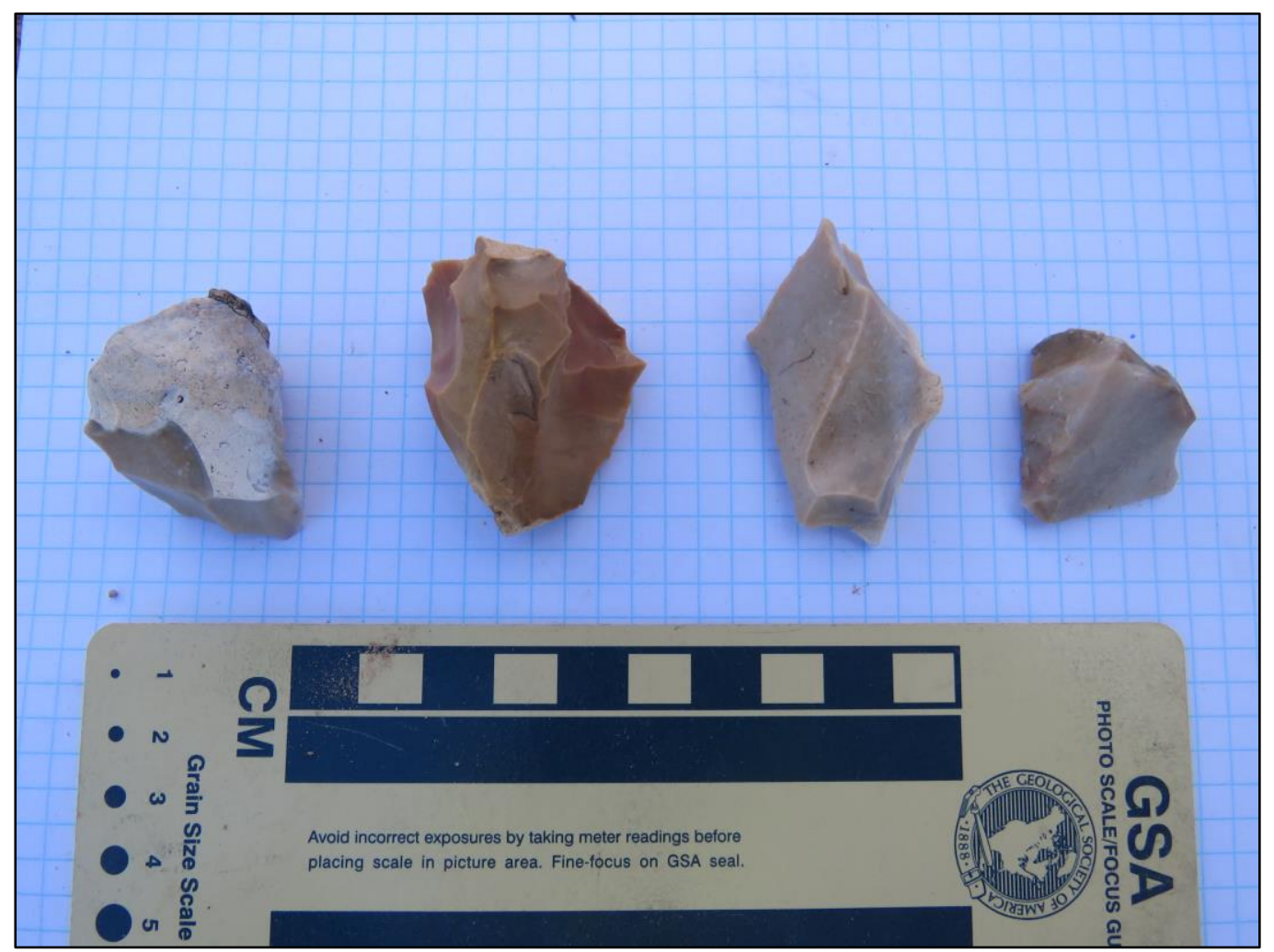

Figure 27: Exhausted core assemblage from site 41RV 208.

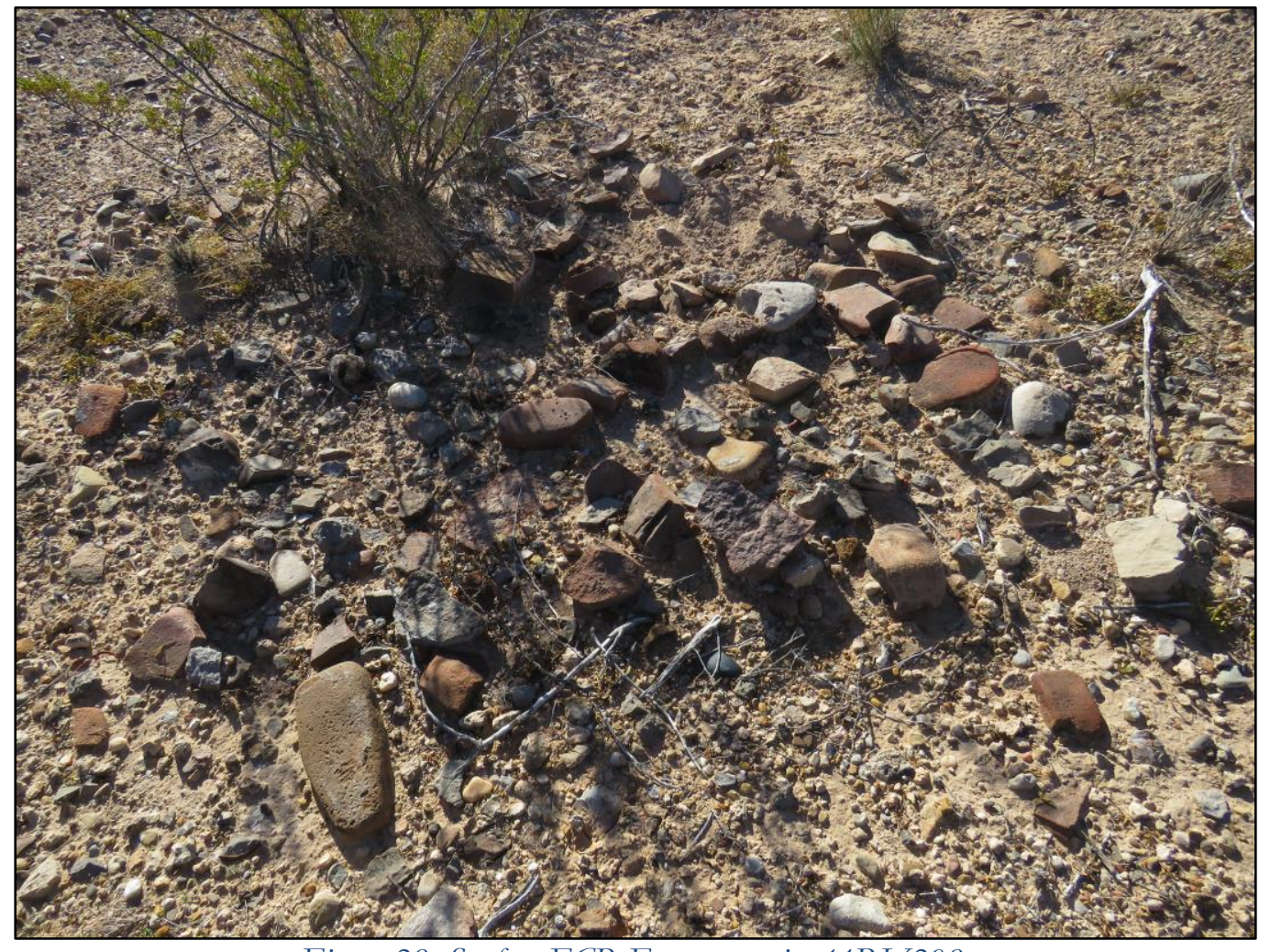

Figure 28: Surface FCR Feature at site 41RV208. 


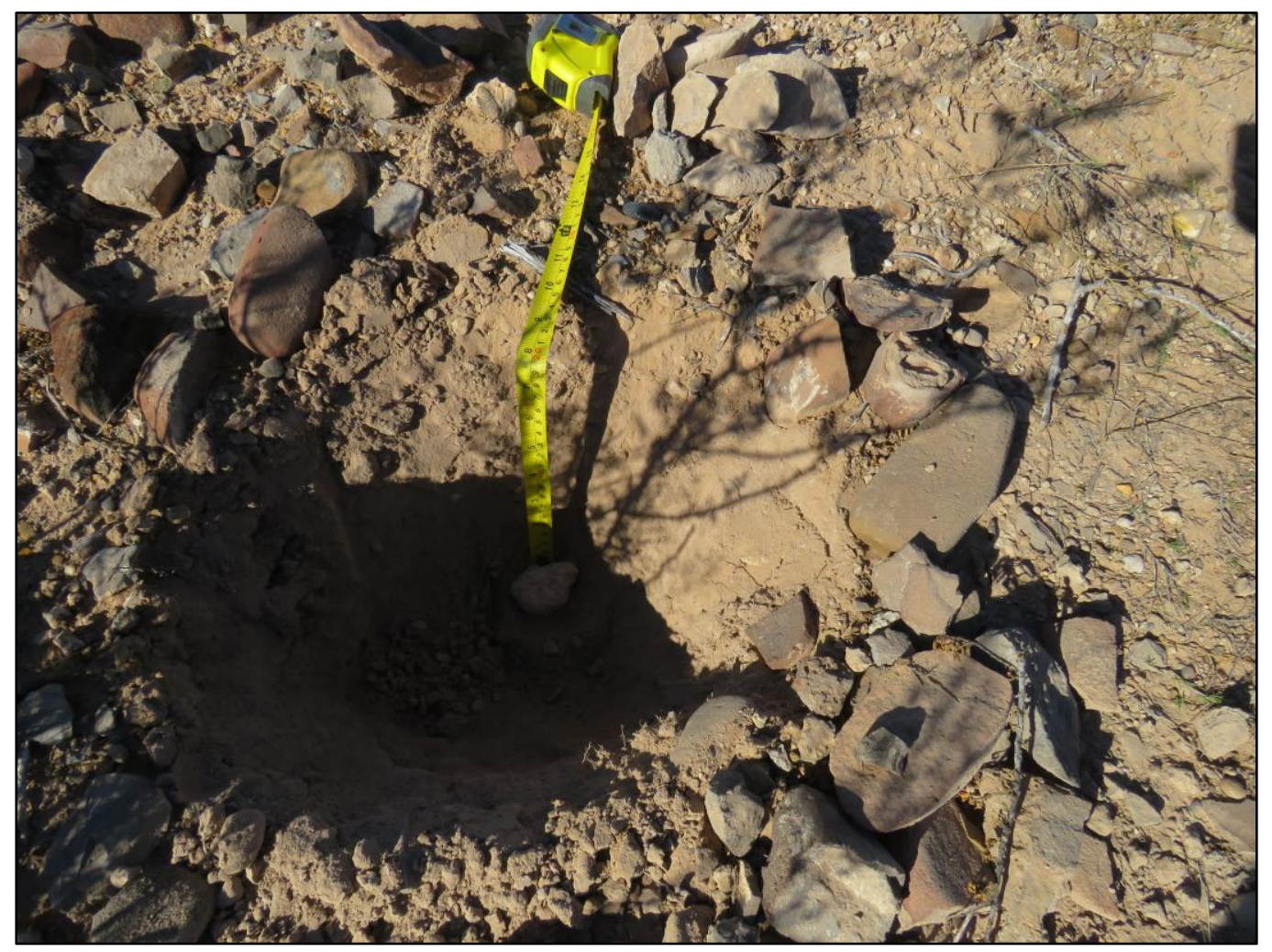

Figure 29: 0-20 cm cross section of FCR feature.

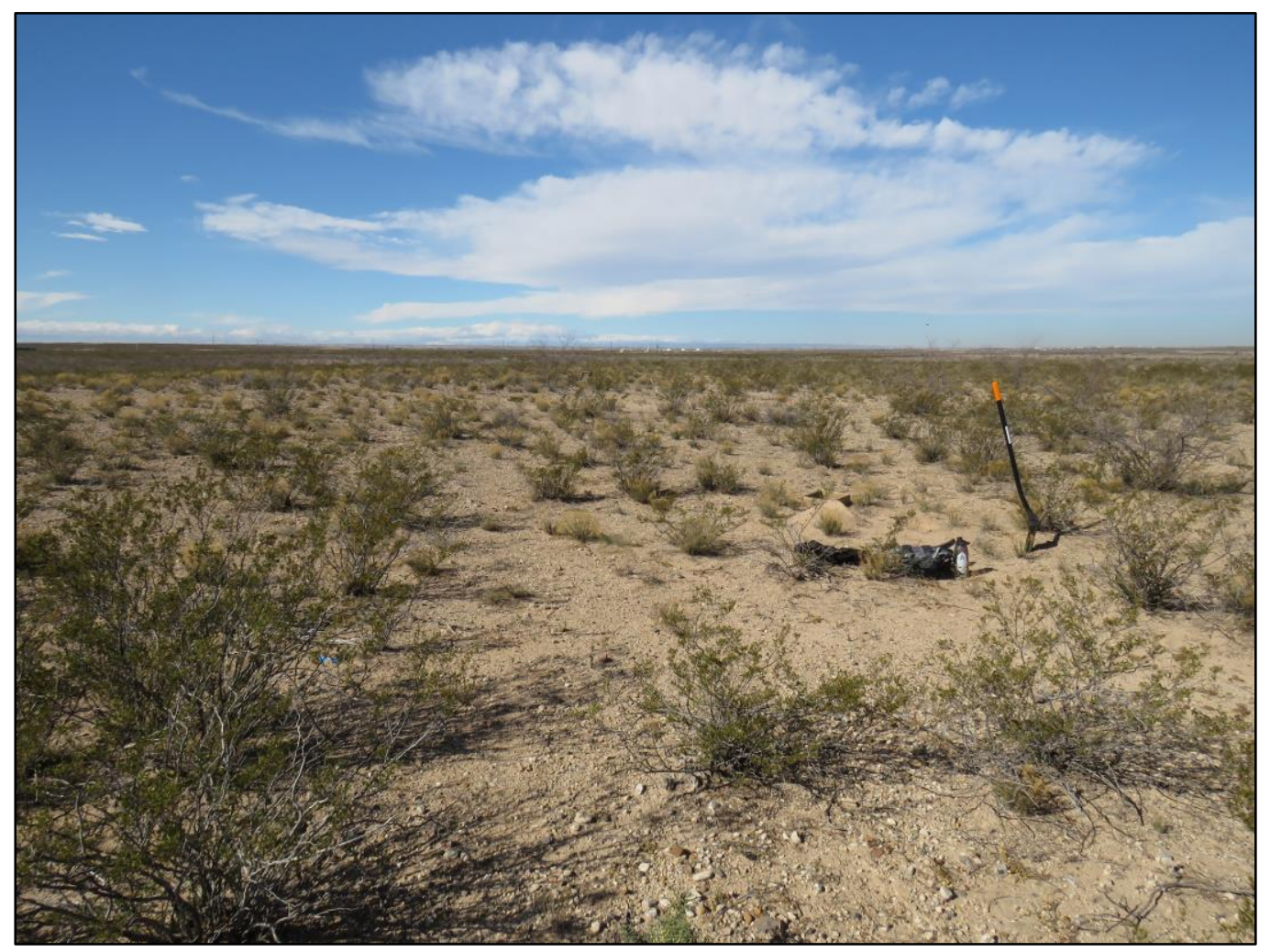

Figure 30: Overview of site 41RV208 from eastern boundary, looking west. 


\section{$\underline{\text { Site 41RV209 }}$}

Site 41RV209 consists of a prehistoric occupation situated on the heavily eroded western banks of Salt Creek (Figure 31). The site was discovered during the intensive survey of the Salt Creek HPA and delineated based on the horizontal distribution of artifacts on the surface, and the boundaries of the proposed Route corridor. Ground visibility at the site was around 75 percent due to sparse vegetation consisting mostly of small creosote brush and the topography was nearly flat. The soils were a very compact brown (10YR 5/4) clay loam with a dense underlying gypsiferous layer of the Gatuna Formation at around $20 \mathrm{cmbs}$. The site is bounded by Salt Creek to the east and cleared pipeline corridors to the north and west and covers an area measuring roughly $75 \mathrm{~m}$ east-west by 40 $m$ north-south. The surface scatter of artifacts extends south of the Route corridor approximately 10 $\mathrm{m}$ toward the actively eroding Salt Creek banks. (Figure 32).

\section{Site location redacted}

Figure 31: Site location map for 41RV209. 


\section{Site location redacted}

Figure 32: Plan map for site 41RV209.

All of the artifacts observed at site 41RV208 were confined to the eroded surface and include 12 FCR, 6 lithic debitage, 3 flake tools, 2 cores, 1 uniface, and 1 biface (Figures 33 and 34). The site is disturbed, and the artifact scatter is a secondary deposit displaced by construction activities associated with pipeline corridors that are adjacent to the north and west. The existing ground surface is actively eroding south in drainage cuts that empty into the Salt Creek channel located some 30 meters to the south. Site 41RV209 may have once been an encampment located further north of the current deposit and disturbance/erosion has displaced the materials. Site photographs are provided in Figures 35 and 36.

Similar to site 41RV208, the scarcity of workable crystalline stone material in the surrounding region is reflected in the presence of expedient tools and exhausted cores produced from the chert gravels afforded by the local geologic outcrops. The location of the site overlooking Salt Creek also suggests the area was selected perhaps to procure local biotic and geologic resources. However, due to the surficial and disturbed nature of the site, and lack of diagnostic artifacts and features that could yield significant information about prehistoric lifeways or environments, site 41RV209 is recommended ineligible for NRHP inclusion within the surveyed area and no further work is warranted for the proposed project. 


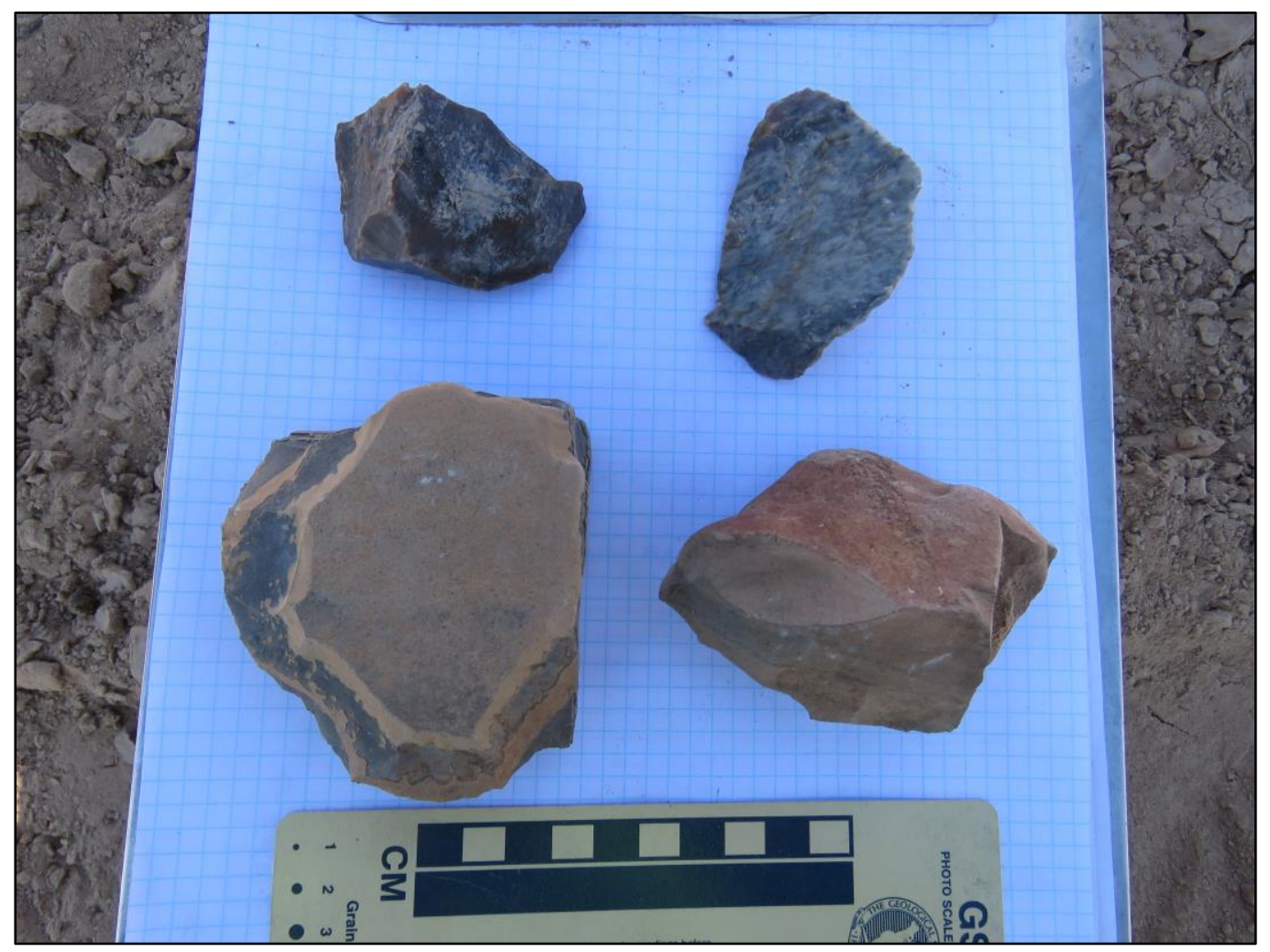

Figure 33: Lithic tool and core assemblage from site 41RV 209.

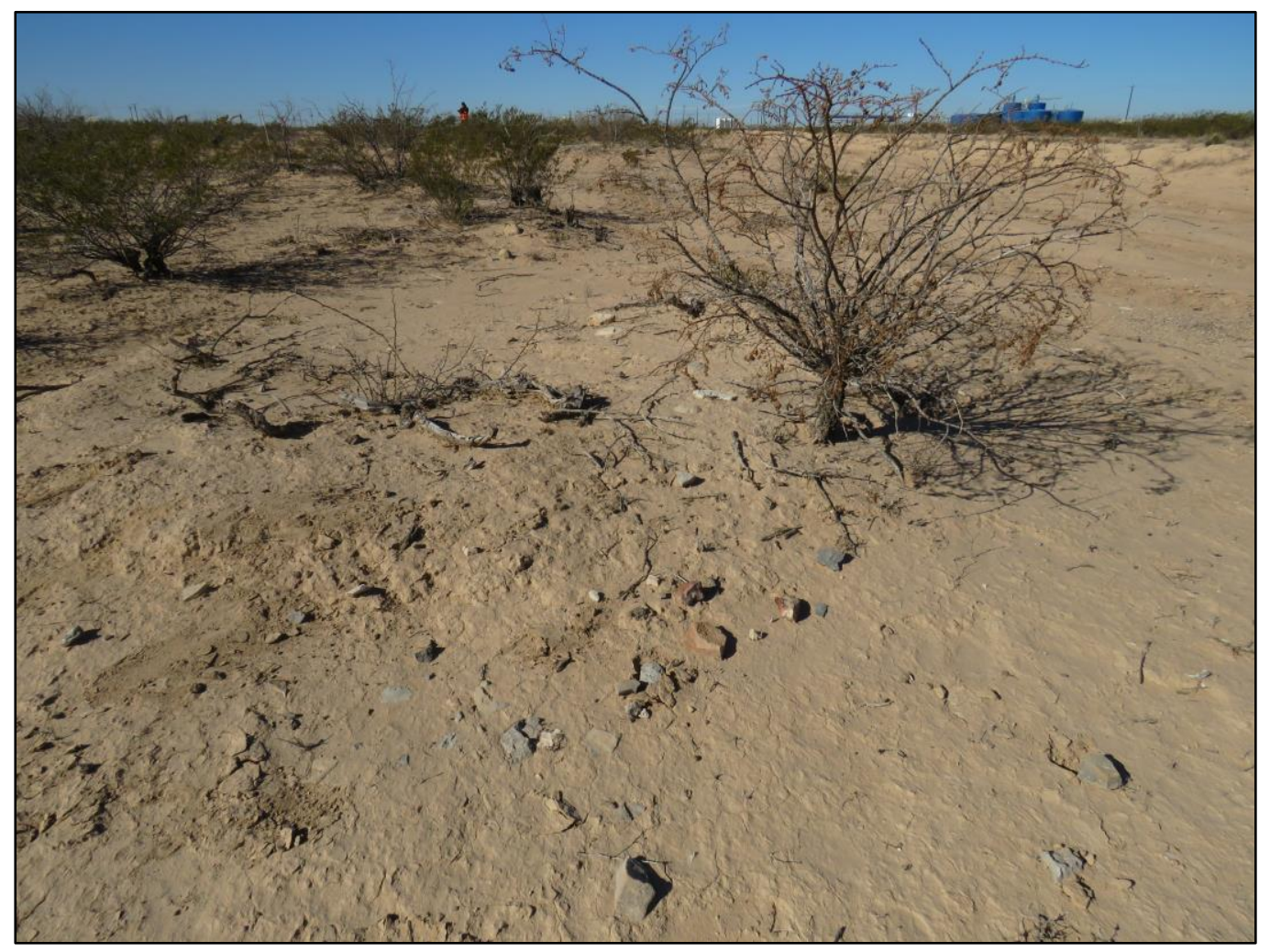

Figure 34: Surface deposits of FCR and pipeline corridor (right) at site 41RV209, looking east. 


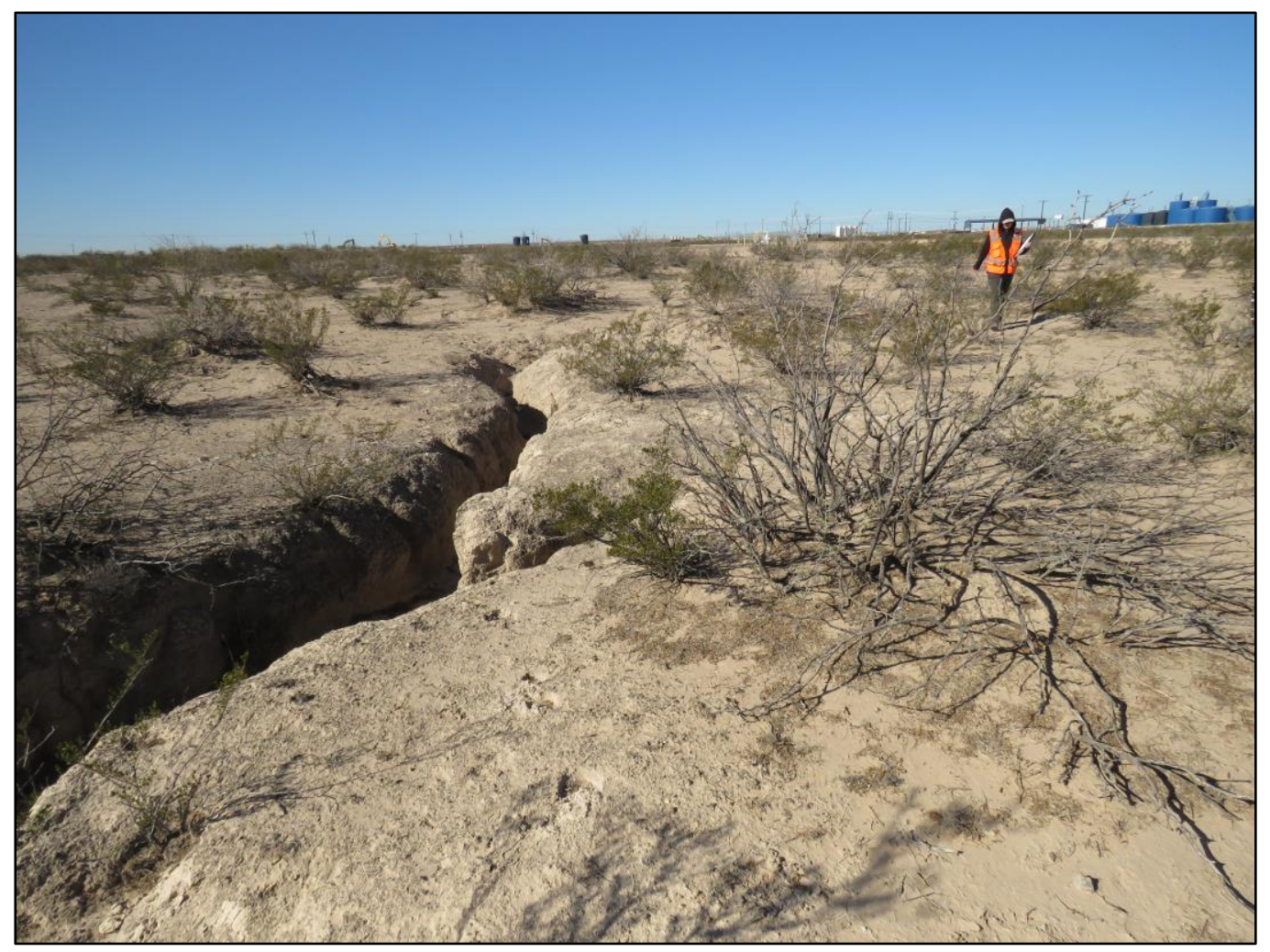

Figure 35: Erosional cuts common at site 41RV209, looking east.

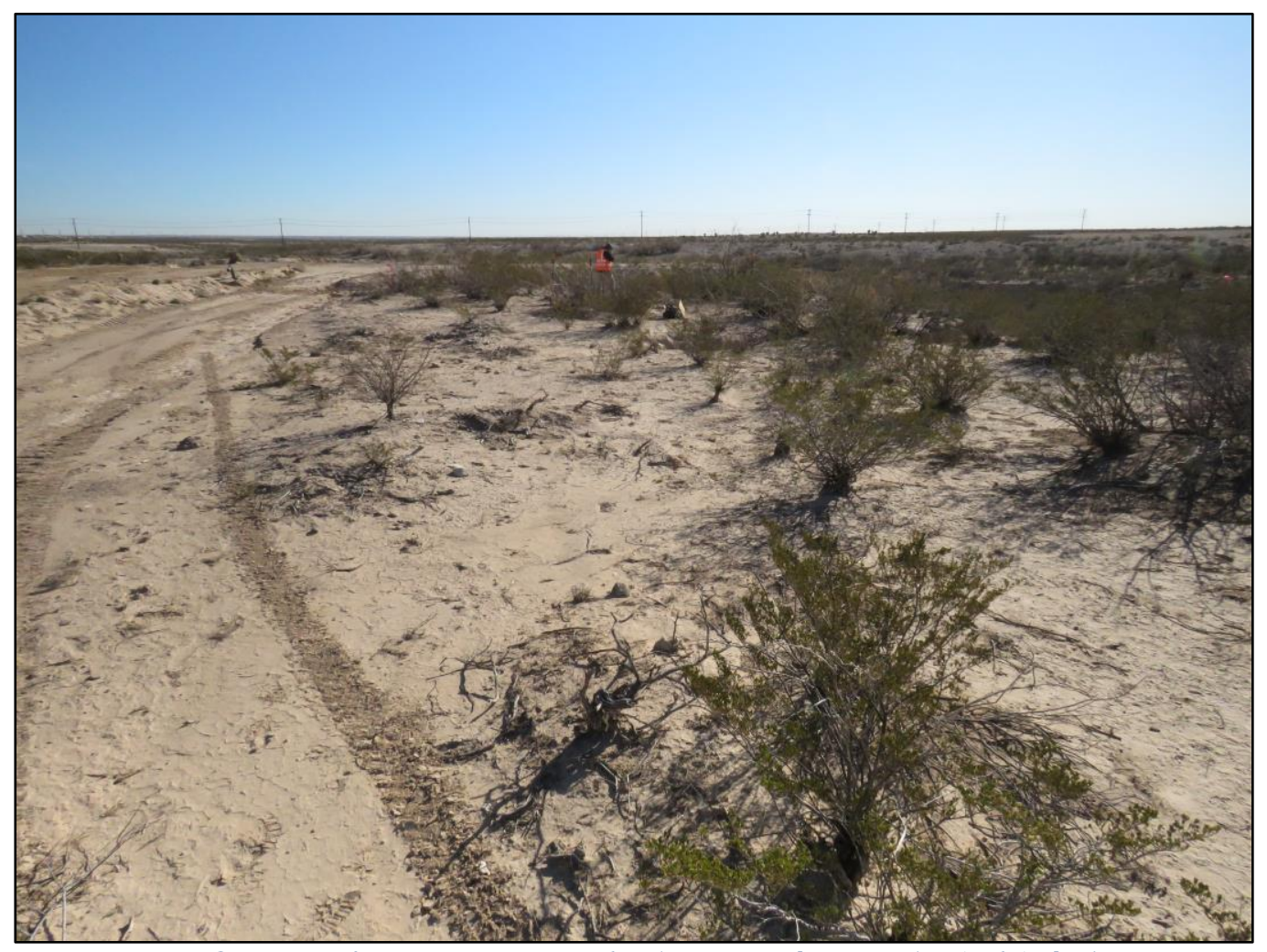

Figure 36: Overview of site 41RV209 with adjacent pipeline corridor (right), looking west. 


\section{$\underline{\text { Site 41RV213 }}$}

Site 41RV213 consists of a section of the historic ATSF railway that is extant on the 1931 Orla Topographic Quadrangle map (USGS 2020b) and the 1968 Red Bluff Quadrangle (see Figure 6). The site is located along the segment of railroad that parallels US 285 to the east approximately 4.5 miles north of the community of Orla, Texas (Figure 37). Although the construction year of this section of the railroad is undetermined, the Santa Fe portion of the ATSF railway reached Texas in 1881 with the completion of its line from Albuquerque to El Paso (Bryant 2010). The railroad in and around the $\mathrm{APE}$ is no longer in use and has been reduced to an approximately 3-m wide linear piling of mainly railroad gravels with sparse non-descript scrap metal debris that runs northwest-southeast through the APE (Figure 39). Cleared pipeline corridors abut the abandoned railway on both sides (Figure 40). The line has been converted to a gravel road southeast of the APE that extends towards the bridge crossing over Salt Creek (see Figure 39). Due to extensive previous disturbance, the portion of site 41RV213 located within the APE is considered a non-contributing element to the railroad's overall NRHP eligibility, and no further work is recommended in the surveyed area. However, the NRHP eligibility of the railway sections outside of the APE remains undetermined.

\section{Site location redacted}

Figure 37: Site location map for 41RV213. 
Intensive Archeological Survey of the

Owl Hills-Tunstill 138-kV Transmission Line Route

Site location redacted

Figure 38: Plan map for site 41RV213. 
Intensive Archeological Survey of the

Owl Hills_-Tunstill 138-kV Transmission Line Route

\section{\# HALFF}

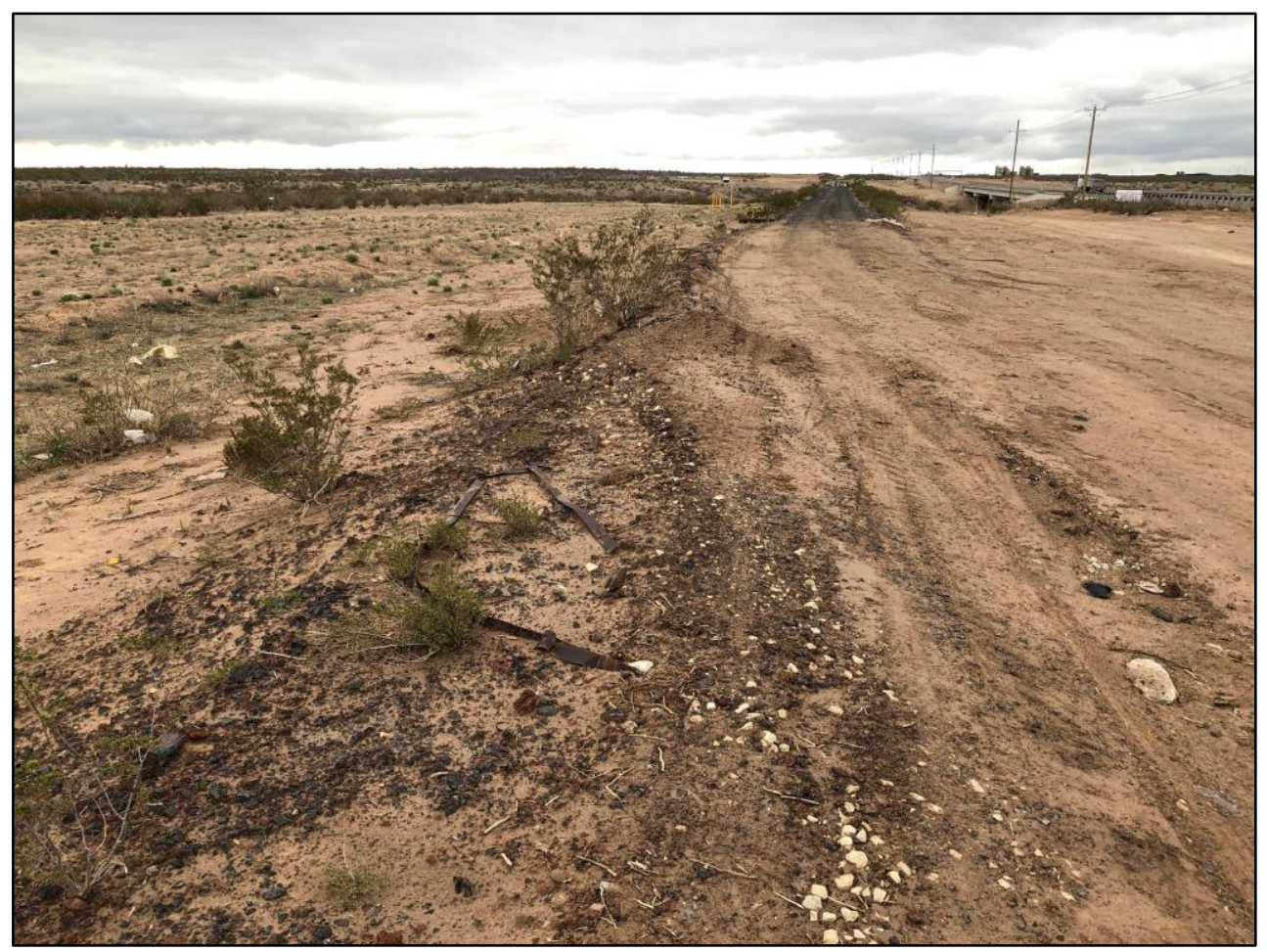

Figure 39: Overview of site 41RV213, showing gravel and scrap metal, facing southeast.

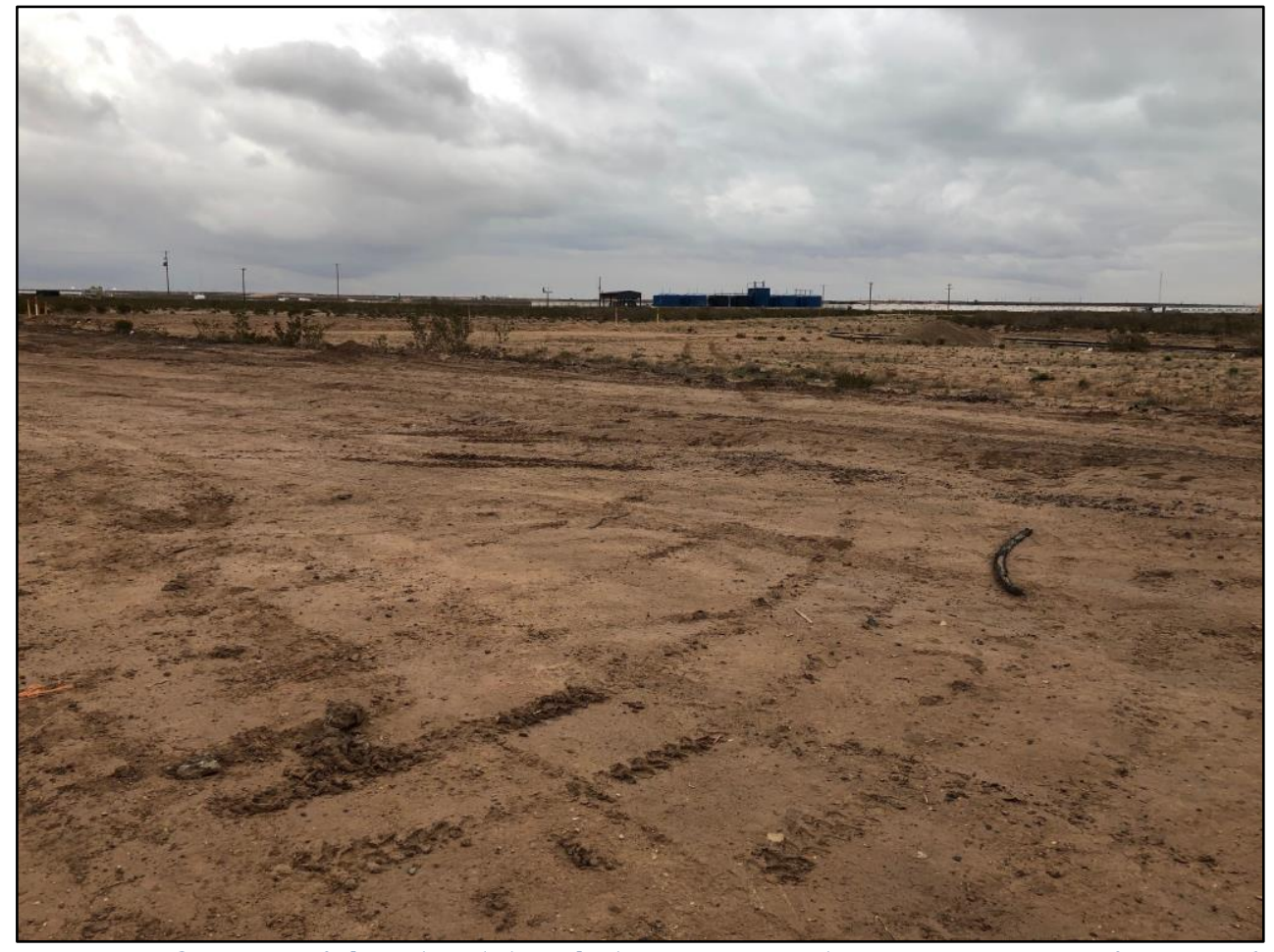

Figure 40: Overview of cleared and disturbed areas surrounding site 41RV213, facing north. 


\section{Conclusions}

Two prehistoric archeological sites were recorded in the HPAs identified for Pecos River and Salt Creek/ATSF. This was expected due to the perennial nature of the waterways, overall reliability of local biotic resources, and the raw stone material afforded by the local geology, all of which likely attracted prehistoric hunter-gatherer groups occupying the region. However, the cultural materials at both sites are in surficial context, and not found buried in the alluvial floodplain as anticipated, especially within the Pecos River valley where culturally sterile soils extended to some $100 \mathrm{cmbs}$. Historic-age site 41RV213 was documented in the Salt Creek/ATSF HPA as expected given its presence on historic topographic maps; however, the section of the railroad within the APE has been extensively disturbed from commercial development in the surrounding area. No further work is recommended in the APE portion of the three archeological sites identified during the field survey.

\section{SUMMARY AND RECOMMENDATIONS}

The purpose of the intensive pedestrian archeological survey was to determine if significant cultural resources are present within the proposed Owl Hills-Tunstill 138-kV Transmission Line Route located in Culberson, Reeves and Loving County, Texas. Two prehistoric sites (41RV208 and 41RV209) and one historic site (41RV213) were recorded during the intensive pedestrian survey and all three sites are recommended as ineligible for NRHP inclusion within the APE.

While shovel testing within the lower terraces of the Pecos River valley floor resulted in negative findings, the majority of shovel tests in this area did not encounter restrictive deposits (e.g., bedrock, basal clay, water table, etc.) or soils that antedate the Holocene. Therefore, it is recommended that installation of the transmission line poles located along the lower alluvial terraces of the Pecos River (Figure 41) be monitored by a professional archeologist. The length of the recommended construction monitoring section is approximately $2.5 \mathrm{~km}$ (1.6 miles) and the results of the investigations will be summarized in a monitoring report submitted for THC review.

Halff recommends that construction of the remainder of the proposed transmission line route be allowed to proceed and that no additional archaeological investigations are recommended outside of the monitoring area. However, should the proposed Route alignment change, additional archaeological survey may be necessary. In addition, if previously unidentified archaeological artifacts, features, or deposits are encountered during construction, it is recommended that the discovery be evaluated by a professional archaeologist in consultation with THC. 

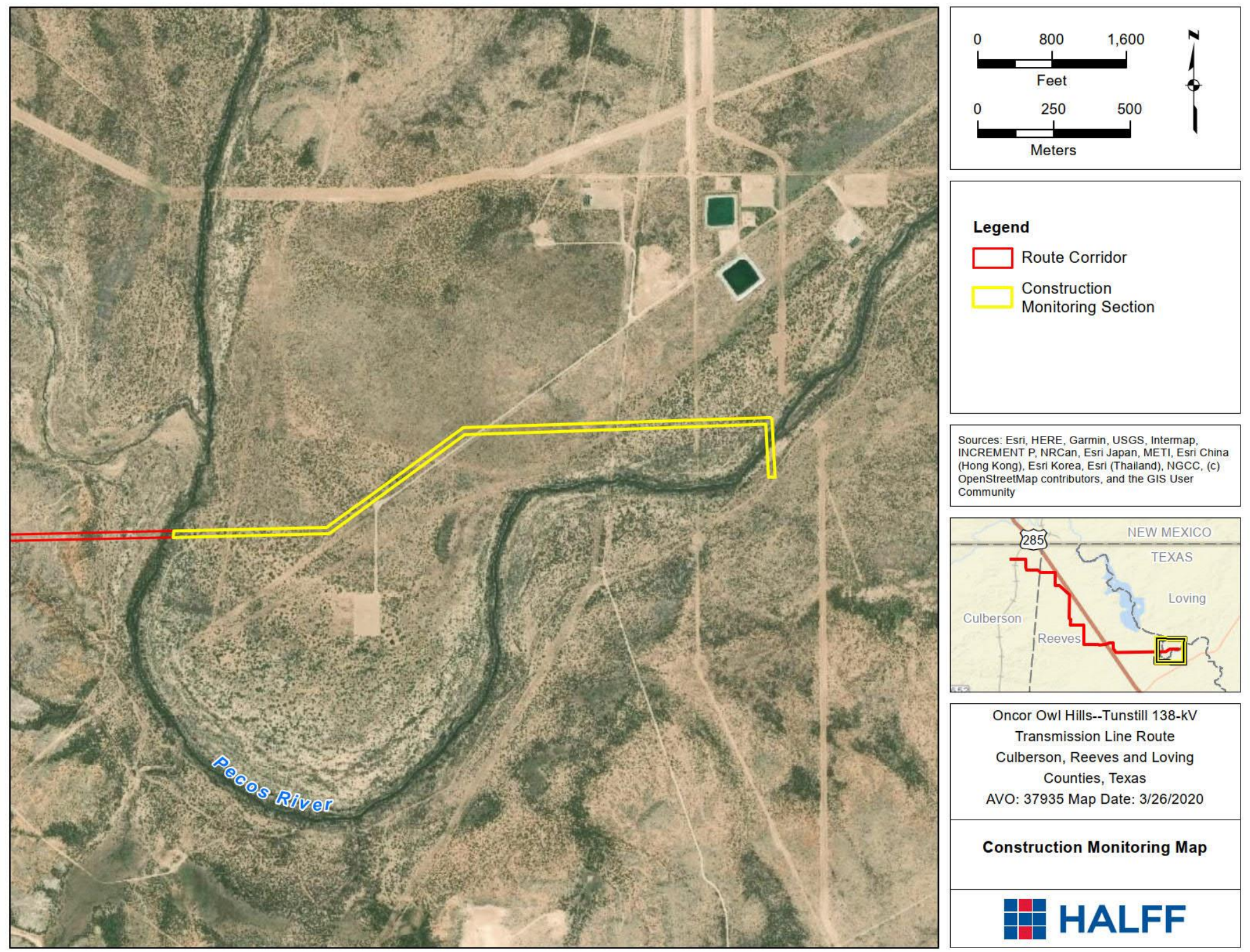

Legend

$\square$ Route Corridor

Construction

Monitoring Section

Figure 41: Map of recommended construction monitoring area. 


\section{REFERENCES}

Bever, Michael R. and David J. Meltzer

2007 Exploring Variation in Paleoindian Life Ways: The Third Revised Edition of the Texas Clovis Fluted Point Survey. Bulletin of the Texas Archeological Society 78:65-100.

Bryant, Keith L.

2010 Atchison, Topeka and Santa Fe Railway System. Handbook of Texas Online. http://www.tshaonline.org/handbook/online/articles/eqa10, accessed March 4, 2020.

Carmichael, D.L.

1986 Archaeological Survey in the Southern Tularosa Basin of New Mexico. Historic and Natural Resources Report No. 3. Environmental Management Office, Directorate of Engineering and Housing, U.S. Army Air Defense Artillery Center, Fort Bliss, TX.

Council of Texas Archeologists

2020 Guidelines for the Content of Cultural Resource Management Reports.

http://www.thc.texas.gov/public/upload/CTAguidelines.pdf, accessed January 15, 2020.

Everitt, B.L.

1977 Historical Background. In A Preliminary Appraisal of Cultural and Historical Resources Found along the Rio Grande between Fort Quitman and Haciendita, Texas, by C.A. Thompson II, pp. 21-25, Publications in Anthropology No. 5. Centennial Museum, University of Texas at El Paso.

Graves, J.

2002 Texas Rivers. Texas Parks and Wildlife Press, Austin, Texas.

Griffith, Glenn, Sandy Bryce, James Omernik, and Anne Rogers

2007 Ecoregions of Texas. Report prepared for the Texas Commission on Environmental Quality, Austin.

Hays, Joe S., Robert L. Brooks, and Jack L. Hofman

1989 Historical Archeology in the Southern Great Plains. In From Clovis to Comanchero: Archaeological Overview of the Southern Great Plain, pp. 101-110. Arkansas Archeological Research Series, No. 35. Fayetteville.

Johnson, L. and G.T. Goode

1994 A New Try at Dating and Characterizing Holocene Climates, as well as Archeological Periods, on the Eastern Edwards Plateau. Bulletin of the Texas Archeological Society 65:1-51.

Lintz, Christopher, W. Nicholas Trierweiler, Amy C. Earls, Fred M. Oglesby, Michael Blum, Patrick O’Neill, John Kuhl, Richard Holloway, Linda Scott-Cummings, and Dan Scurlock 
1993 Cultural Resources Investigations in the O. H. Ivie Reservoir, Concho, Coleman, and Runnels Counties, Texas. Volume 1: Project Introduction, Setting, and Methods. Technical Report No. 346-I. Mariah Associates, Inc., Austin.

Lindsay, Alexander J., Jr.

1969 Current Research: Southwest Texas. American Antiquity 34(1):99-103.

Mallouf, Robert.

198 A Synthesis of Eastern Trans-Pecos Prehistory. Unpublished Master's thesis. The University of Texas at Austin.

Miller, M.R.

1994 Jornada Mogollon Residential Settlements in the Salt Flat Basin and Delaware Mountains of West Texas. In Mogollon VII: The Collected Papers of the 1992 Mogollon Conference Held in Las Cruces, New Mexico, edited by P.H. Beckettt, pp. 105-114. COAS Publishing and Research, Las Cruces, New Mexico.

Miller, Myles R. and Nancy A. Kenmotsu

2004 Prehistory of the Jornado Mogollon and Eastern Trans-Pecos Regions of West Texas. In The Prehistory of Texas, edited by Timothy K Perttula, pp. 205-266. Texas A\&M University Press, College Station.

Munsell

2009 Munsell Soil-Color Charts. Munsell Color: Grand Rapids, Michigan.

Nationwide Environmental Title Research (NETR)

2020 Historic Aerials. Electronic document, https://www.historicaerials.com/viewer, accessed January 8, 2020.

Natural Resource Conservation Service (NRCS)

2020 Web Soil Survey. Electronic document, https://websoilsurvey.sc.egov.usda.gov/App/ HomePage.htm, accessed January 10, 2020.

\section{PBS\&J}

2008 Generic Research Design for Archaeological Surveys of Oncor Electric Delivery Electric Transmission Line Projects in Texas. Document No. 070050. PBS\&J, Dallas.

Peterson, J.A. and D.O. Brown (editors)

1992 El Valle Bajo: The Culture History of the Lower Rio Grande Valley of El Paso. Vol. 1, Culture and Environment in the Lower V alley. Archeological Research, El Paso. Hicks and Company, Austin. 
Prewitt, Elton R.

1985 From Circleville to Toyah: Comments on Central Texas Chronology. Bulletin of the Texas Archeological Society 54:201-238.

Sebastian, L. and S. Larralde

1989 Living on the Land: 11,000 Years of Human Adaptation in Southeastern New Mexico: An Overview of Cultural Resources in the Roswell District, Bureau of Land Management. Albuquerque: Office of Contract Archeology, University of New Mexico.

Sommers, Arnold.

19741973 SWFAS Early Man Conference. Transactions of the Ninth Regional Archeological Symposium for Southeastern New Mexico and West Texas, pp. 109-141.

Texas Historical Commission (THC)

2020 Texas Archeological Sites Atlas. Electronic document, https://atlas.thc.state.tx.us/ accessed January 10, 2020.

U.S. Geological Survey (USGS)

2020a Geologic Atlas of Texas Viewer. Electronic document, https://txpub.usgs.gov/txgeology/, accessed January 10, 2020.

2020b TopoView. Electronic document, https://ngmdb.usgs.gov/topoview/viewer/\#4/40.01/100.06, accessed February 5, 2020. 


\section{APPENDIX A \\ Shovel Test DATA}




\begin{tabular}{|c|c|c|c|c|c|c|c|c|}
\hline WP No. & ST No. & Easting & Northing & $\begin{array}{l}\text { Depth } \\
\text { (cmbs) }\end{array}$ & Soil Color & Soil Texture & Artifacts & Comments \\
\hline \multirow[t]{2}{*}{ G-1 } & MM-1 & 607504 & 3527175 & $0-75$ & 10YR 5/4 & silty loam & $\mathrm{n} / \mathrm{a}$ & fines downward \\
\hline & & & & $75+$ & $\mathrm{N} / \mathrm{A}$ & $\begin{array}{c}\text { gravel } \\
\text { conglomerate }\end{array}$ & $\mathrm{n} / \mathrm{a}$ & $\begin{array}{l}\text { cemented } \\
\text { material }\end{array}$ \\
\hline G-2 & MM-2 & 607468 & 3527283 & $0-80$ & 5YR 5/4 & fine sandy loam & $\mathrm{n} / \mathrm{a}$ & $\begin{array}{l}\text { at north terrace } \\
\text { of Pecos River; } \\
\text { sterile soil }\end{array}$ \\
\hline \multirow[t]{2}{*}{ G-3 } & MM-3 & 607431 & 3527276 & $0-20$ & 10YR 5/4 & fine sandy loam & $\mathrm{n} / \mathrm{a}$ & \\
\hline & & & & $20-80$ & $2.5 Y R 5 / 4$ & fine sandy loam & $\mathrm{n} / \mathrm{a}$ & \\
\hline G-4 & MM-4 & 607303 & 3527274 & $0-80$ & $5 \mathrm{YR} 5 / 4$ & fine sandy loam & $\mathrm{n} / \mathrm{a}$ & \\
\hline G-5 & MM-5 & 607132 & 3527265 & $0-80$ & 5YR 5/4 & fine sandy loam & $\mathrm{n} / \mathrm{a}$ & \\
\hline G-6 & MM-6 & 607080 & 3527261 & $0-85$ & $5 \mathrm{YR} 5 / 4$ & fine sandy loam & $\mathrm{n} / \mathrm{a}$ & \\
\hline \multirow[t]{3}{*}{ G-7 } & MM-7 & 606871 & 3527256 & $0-20$ & 10YR 5/4 & silty loam & $\mathrm{n} / \mathrm{a}$ & $\begin{array}{l}\text { east of older } \\
\text { gravelly } \\
\text { landform }\end{array}$ \\
\hline & & & & $20-60$ & 5YR 5/4 & $\begin{array}{l}\text { silty loam with } \\
\text { moderate gravels }\end{array}$ & $\mathrm{n} / \mathrm{a}$ & \\
\hline & & & & $60-70$ & 5YR 5/4 & $\begin{array}{l}\text { silty loam with } \\
\text { abundant gravels }\end{array}$ & $\mathrm{n} / \mathrm{a}$ & \\
\hline \multirow[t]{2}{*}{ G-8 } & MM-8 & 606668 & 3527249 & $0-40$ & $5 \mathrm{YR} 5 / 4$ & silty clay loam & $\mathrm{n} / \mathrm{a}$ & $\begin{array}{l}\text { gravelly } \\
\text { landform }\end{array}$ \\
\hline & & & & $40-55$ & $5 \mathrm{YR} 5 / 4$ & $\begin{array}{l}\text { clay loam with } \\
\text { abundant gravels }\end{array}$ & $\mathrm{n} / \mathrm{a}$ & \\
\hline \multirow[t]{3}{*}{ G-9 } & MM-9 & 606620 & 3527245 & $0-15$ & 5YR 5/4 & $\begin{array}{l}\text { silty loam with } \\
\text { few gravels }\end{array}$ & $\mathrm{n} / \mathrm{a}$ & $\begin{array}{l}\text { gravelly } \\
\text { landform }\end{array}$ \\
\hline & & & & $15-50$ & 5YR 5/4 & $\begin{array}{l}\text { silty loam with } \\
\text { common gravels }\end{array}$ & $\mathrm{n} / \mathrm{a}$ & \\
\hline & & & & $50-60$ & 5YR 5/4 & $\begin{array}{l}\text { silty loam with } \\
\text { abundant gravels }\end{array}$ & $\mathrm{n} / \mathrm{a}$ & \\
\hline
\end{tabular}




\begin{tabular}{|c|c|c|c|c|c|c|c|c|}
\hline WP No. & ST No. & Easting & Northing & $\begin{array}{l}\text { Depth } \\
\text { (cmbs) }\end{array}$ & Soil Color & Soil Texture & Artifacts & Comments \\
\hline \multirow[t]{2}{*}{ G-10 } & MM-10 & 606361 & 3527145 & $0-70$ & 10YR 5/4 & fine sandy loam & $\mathrm{n} / \mathrm{a}$ & $\begin{array}{l}\text { lower alluvial } \\
\text { terrace }\end{array}$ \\
\hline & & & & $70-90$ & 5YR 5/4 & fine sandy loam & $\mathrm{n} / \mathrm{a}$ & dune sand \\
\hline G-11 & MM-11 & 606200 & 3527025 & $0-85$ & 10YR 5/4 & fine sandy loam & $\mathrm{n} / \mathrm{a}$ & \\
\hline \multirow[t]{2}{*}{ G-12 } & MM-12 & 605994 & 3526907 & $0-60$ & 10YR 5/4 & silty clay loam & $\mathrm{n} / \mathrm{a}$ & \\
\hline & & & & $60-75$ & 10YR 5/4 & $\begin{array}{c}\text { silty clay loam } \\
\text { with moderate } \\
\text { calcium } \\
\text { inclusions }\end{array}$ & $\mathrm{n} / \mathrm{a}$ & compact \\
\hline G-13 & MM-13 & 605789 & 3526908 & $0-85$ & 10YR 5/4 & fine sandy loam & $\mathrm{n} / \mathrm{a}$ & dune sand \\
\hline G-14 & MM-14 & 605632 & 3526906 & $0-85$ & 10YR 5/4 & fine sandy loam & $\mathrm{n} / \mathrm{a}$ & $\begin{array}{l}\text { ca. } 50 \mathrm{~m} \text { east of } \\
\text { western Pecos } \\
\text { River crossing }\end{array}$ \\
\hline \multirow[t]{2}{*}{ G-15 } & MM-15 & 605262 & 3526896 & $0-65$ & 10YR 5/3 & silty clay loam & $\mathrm{n} / \mathrm{a}$ & $\begin{array}{l}\text { western lower } \\
\text { terrace near base } \\
\text { of valley rim }\end{array}$ \\
\hline & & & & $65-75$ & 10YR 5/4 & $\begin{array}{c}\text { calcareous clay } \\
\text { loam }\end{array}$ & $\mathrm{n} / \mathrm{a}$ & compact \\
\hline G-16 & MM-16 & 605371 & 3526907 & $0-90$ & 10YR 5/4 & fine sandy loam & $\mathrm{n} / \mathrm{a}$ & $\begin{array}{l}\text { western lower } \\
\text { terrace near base } \\
\text { of valley rim }\end{array}$ \\
\hline G-17 & $\begin{array}{c}\text { OHT-1- } \\
3\end{array}$ & $\begin{array}{l}\text { UTM } \\
\text { redacted }\end{array}$ & $\begin{array}{l}\text { UTM } \\
\text { redacted }\end{array}$ & $0-4$ & 10YR 5/3 & silty clay loam & $\begin{array}{c}13 \text { FCR } \\
4-10 \mathrm{~cm} \text { in } \\
\text { size }\end{array}$ & $\begin{array}{l}\text { dug in NE } \\
\text { corner of FCR } \\
\text { Feature, site } \\
\text { OHT-1 } \\
(41 \mathrm{RV} 208)\end{array}$ \\
\hline & & & & $4+$ & $\mathrm{N} / \mathrm{A}$ & dense gravels & $\mathrm{n} / \mathrm{a}$ & \\
\hline
\end{tabular}




\begin{tabular}{|c|c|c|c|c|c|c|c|c|}
\hline WP No. & ST No. & Easting & Northing & $\begin{array}{l}\text { Depth } \\
\text { (cmbs) }\end{array}$ & Soil Color & Soil Texture & Artifacts & Comments \\
\hline \multirow[t]{2}{*}{ G-18 } & MM-17 & 603418 & 3526868 & $0-35$ & 7.5YR 5/4 & $\begin{array}{l}\text { silty clay loam } \\
\text { with common } \\
\text { gravels }\end{array}$ & $\mathrm{n} / \mathrm{a}$ & \\
\hline & & & & $35-45$ & $7.5 \mathrm{YR} 8 / 2$ & dense gypsum & $\mathrm{n} / \mathrm{a}$ & bedrock \\
\hline \multirow[t]{2}{*}{ G-19 } & MM-18 & 603475 & 3526864 & $0-40$ & $7.5 Y R 5 / 4$ & $\begin{array}{c}\text { silty clay loam } \\
\text { with common } \\
\text { gravels }\end{array}$ & $\mathrm{n} / \mathrm{a}$ & \\
\hline & & & & $40-50$ & $7.5 Y R 5 / 3$ & $\begin{array}{c}\text { gypsiferous clay } \\
\text { loam }\end{array}$ & $\mathrm{n} / \mathrm{a}$ & compact \\
\hline \multirow[t]{2}{*}{ G-20 } & MM-19 & 603525 & 3526859 & $0-30$ & $7.5 Y R 5 / 4$ & $\begin{array}{c}\text { silty clay loam } \\
\text { with common } \\
\text { gravels }\end{array}$ & $\mathrm{n} / \mathrm{a}$ & \\
\hline & & & & $30-40$ & $7.5 Y R 5 / 3$ & $\begin{array}{c}\text { gypsiferous clay } \\
\text { loam }\end{array}$ & $\mathrm{n} / \mathrm{a}$ & compact \\
\hline \multirow[t]{3}{*}{ G-21 } & MM-20 & 603583 & 3526862 & $0-30$ & $7.5 Y R \quad 4 / 4$ & silty clay & $\mathrm{n} / \mathrm{a}$ & \\
\hline & & & & $30-40$ & $7.5 \mathrm{YR} 4 / 4$ & $\begin{array}{c}\text { gypsiferous clay } \\
\text { loam }\end{array}$ & $\mathrm{n} / \mathrm{a}$ & compact \\
\hline & & & & $40-50$ & $7.5 \mathrm{YR} 8 / 2$ & dense gypsum & $\mathrm{n} / \mathrm{a}$ & bedrock \\
\hline \multirow[t]{2}{*}{ G-22 } & MM-21 & 603664 & 3526867 & $0-40$ & $7.5 \mathrm{YR} 4 / 4$ & silty clay loam & $\mathrm{n} / \mathrm{a}$ & compact \\
\hline & & & & $40-50$ & $7.5 \mathrm{YR} 4 / 4$ & $\begin{array}{c}\text { gypsiferous clay } \\
\text { loam }\end{array}$ & $\mathrm{n} / \mathrm{a}$ & compact \\
\hline \multirow[t]{2}{*}{ G-25 } & MM-22 & 602259 & 3526832 & $0-60$ & $7.5 \mathrm{YR} 4 / 4$ & clay loam & $\mathrm{n} / \mathrm{a}$ & $\begin{array}{l}\text { tributary of Salt } \\
\text { Creek }\end{array}$ \\
\hline & & & & $60-70$ & $7.5 \mathrm{YR} 4 / 4$ & $\begin{array}{c}\text { gypsiferous clay } \\
\text { loam }\end{array}$ & $\mathrm{n} / \mathrm{a}$ & \\
\hline G-26 & MM-23 & 600158 & 3527999 & $0-30$ & 7.5YR $8 / 2$ & loam & $\mathrm{n} / \mathrm{a}$ & $\begin{array}{l}\text { disturbed soil } \\
\text { from adjacent } \\
\text { utility }\end{array}$ \\
\hline
\end{tabular}




\begin{tabular}{|c|c|c|c|c|c|c|c|c|}
\hline WP No. & ST No. & Easting & Northing & $\begin{array}{l}\text { Depth } \\
\text { (cmbs) }\end{array}$ & Soil Color & Soil Texture & Artifacts & Comments \\
\hline \multirow[t]{2}{*}{ G-30 } & MM-24 & 594539 & 3534973 & $0-55$ & 10YR 5/3 & silty clay & $\mathrm{n} / \mathrm{a}$ & $\begin{array}{l}\text { compact; at } \\
\text { China Draw }\end{array}$ \\
\hline & & & & $55-65$ & 10YR 5/3 & $\begin{array}{l}\text { clay loam with } \\
\text { common gravels }\end{array}$ & $\mathrm{n} / \mathrm{a}$ & $\begin{array}{l}\text { sandstone } \\
\text { gravels }\end{array}$ \\
\hline \multirow[t]{2}{*}{$\mathrm{X}-1$} & SF-1 & 607336 & 3527266 & $0-20$ & 10YR 5/4 & silty loam & $\mathrm{n} / \mathrm{a}$ & \\
\hline & & & & $20-60$ & $2.5 Y R$ 5/4 & silty loam & $\mathrm{n} / \mathrm{a}$ & \\
\hline $\mathrm{X}-2$ & SF-2 & 607167 & 3527267 & $0-80$ & 5YR 5/4 & silty loam & $\mathrm{n} / \mathrm{a}$ & \\
\hline \multirow[t]{2}{*}{$\mathrm{X}-3$} & SF-3 & 606915 & 3527258 & $0-45$ & 5YR 5/4 & silty loam & $\mathrm{n} / \mathrm{a}$ & \\
\hline & & & & $45-80$ & $5 Y R 5 / 4$ & $\begin{array}{l}\text { silty loam with } \\
\text { common gravels }\end{array}$ & $\mathrm{n} / \mathrm{a}$ & \\
\hline \multirow[t]{2}{*}{$\mathrm{X}-4$} & SF-4 & 606707 & 3527252 & $0-40$ & 5YR 5/4 & silty loam & $\mathrm{n} / \mathrm{a}$ & \\
\hline & & & & $40-80$ & 5YR 5/4 & silty clay loam & $\mathrm{n} / \mathrm{a}$ & \\
\hline \multirow[t]{2}{*}{$\mathrm{X}-5$} & SF-5 & 606411 & 3527180 & $0-35$ & 5YR 5/4 & silty loam & $\mathrm{n} / \mathrm{a}$ & \\
\hline & & & & $35-80$ & 5YR 5/4 & silty clay loam & $\mathrm{n} / \mathrm{a}$ & \\
\hline $\mathrm{X}-6$ & SF-6 & 606235 & 3527049 & $0-80$ & 10YR 5/4 & fine sandy loam & $\mathrm{n} / \mathrm{a}$ & \\
\hline $\mathrm{X}-7$ & SF-7 & 606067 & 3526927 & $0-80$ & 10YR 5/4 & fine sandy loam & $\mathrm{n} / \mathrm{a}$ & \\
\hline $\mathrm{X}-8$ & SF-8 & 605837 & 3526911 & $0-80$ & 10YR 5/4 & fine sandy loam & $\mathrm{n} / \mathrm{a}$ & dune sand \\
\hline \multirow[t]{2}{*}{$\mathrm{X}-9$} & SF-9 & 605587 & 3526905 & $0-40$ & 10YR 5/4 & silty loam & $\mathrm{n} / \mathrm{a}$ & \\
\hline & & & & $40-80$ & 10YR 5/4 & silty clay loam & $\mathrm{n} / \mathrm{a}$ & \\
\hline \multirow[t]{2}{*}{$\mathrm{X}-10$} & SF-10 & 605306 & 3526897 & $0-65$ & 10YR 5/3 & silty clay loam & $\mathrm{n} / \mathrm{a}$ & \\
\hline & & & & $65-75$ & 10YR 5/4 & $\begin{array}{c}\text { calcareous clay } \\
\text { loam }\end{array}$ & $\mathrm{n} / \mathrm{a}$ & \\
\hline $\mathrm{X}-11$ & SF-11 & 605222 & 3526899 & $0-80$ & 10YR 5/4 & fine sandy loam & $\mathrm{n} / \mathrm{a}$ & \\
\hline $\mathrm{X}-12$ & $\begin{array}{c}\text { OHT-1- } \\
1\end{array}$ & 605117 & 3526896 & $0-40$ & 10YR 5/3 & $\begin{array}{c}\text { silty clay with } \\
\text { abundant gravels }\end{array}$ & $\mathrm{n} / \mathrm{a}$ & $\begin{array}{l}\text { Flakes observed } \\
\text { on surface } \\
\text { surrounding } \\
\text { shovel test; } \\
\text { nothing buried } \\
\text { in shovel test }\end{array}$ \\
\hline \multirow[t]{2}{*}{$\mathrm{X}-13$} & SF-13 & 604053 & 3526872 & $0-30$ & 7.5YR 5/4 & $\begin{array}{c}\text { silty clay loam } \\
\text { with common } \\
\text { gravels }\end{array}$ & $\mathrm{n} / \mathrm{a}$ & \\
\hline & & & & $30-40$ & $7.5 Y R 5 / 3$ & $\begin{array}{c}\text { gypsiferous clay } \\
\text { loam }\end{array}$ & $\mathrm{n} / \mathrm{a}$ & compact \\
\hline
\end{tabular}




\begin{tabular}{|c|c|c|c|c|c|c|c|c|}
\hline WP No. & ST No. & Easting & Northing & $\begin{array}{l}\text { Depth } \\
\text { (cmbs) }\end{array}$ & Soil Color & Soil Texture & Artifacts & Comments \\
\hline $\mathrm{X}-14$ & SF-14 & 603958 & 3526869 & $0-40$ & $7.5 \mathrm{YR} 4 / 4$ & silty clay loam & $\mathrm{n} / \mathrm{a}$ & \\
\hline & & & & $40-50$ & $7.5 \mathrm{YR} 4 / 4$ & $\begin{array}{c}\text { gypsiferous clay } \\
\text { loam }\end{array}$ & $\mathrm{n} / \mathrm{a}$ & compact \\
\hline $\mathrm{X}-16$ & SF-16 & 603784 & 3526868 & $0-60$ & $7.5 \mathrm{YR} 4 / 4$ & clay loam & $\mathrm{n} / \mathrm{a}$ & \\
\hline $\mathrm{X}-17$ & SF-17 & 603735 & 3526865 & $0-45$ & 10YR 5/3 & $\begin{array}{l}\text { silty loam with } \\
\text { few gravels }\end{array}$ & $\mathrm{n} / \mathrm{a}$ & \\
\hline $\mathrm{X}-18$ & SF-18 & 594477 & 3535031 & $0-50$ & $10 Y R 5 / 3$ & clay & $\mathrm{n} / \mathrm{a}$ & compact \\
\hline $\mathrm{Y}-1$ & MO-1 & 607501 & 3527112 & $0-80$ & 10YR 5/3 & fine sandy loam & $\mathrm{n} / \mathrm{a}$ & \\
\hline $\mathrm{Y}-2$ & MO-2 & 607504 & 3527249 & $0-80$ & 10YR 5/3 & fine sandy loam & $\mathrm{n} / \mathrm{a}$ & \\
\hline Y-3 & MO-3 & 607398 & 3527276 & $0-80$ & 10 YR $5 / 3$ & fine sandy loam & $\mathrm{n} / \mathrm{a}$ & \\
\hline Y-4 & $\mathrm{MO}-4$ & 607240 & 3527267 & $0-80$ & 10YR 5/3 & fine sandy loam & $\mathrm{n} / \mathrm{a}$ & \\
\hline $\mathrm{Y}-5$ & MO-5 & 607033 & 3527263 & $0-80$ & 10 YR $5 / 3$ & fine sandy loam & $\mathrm{n} / \mathrm{a}$ & \\
\hline Y-6 & MO-6 & 606822 & 3527252 & $0-70$ & 10YR 5/3 & fine sandy loam & $\mathrm{n} / \mathrm{a}$ & $\begin{array}{l}\text { dense gravel at } \\
\text { base }\end{array}$ \\
\hline Y-7 & $\mathrm{MO}-7$ & 606527 & 3527243 & $0-80$ & 10YR 5/3 & fine sandy loam & $\mathrm{n} / \mathrm{a}$ & \\
\hline $\mathrm{Y}-8$ & MO-8 & 606324 & 3527112 & $0-80$ & 10YR 5/3 & fine sandy loam & $\mathrm{n} / \mathrm{a}$ & \\
\hline Y-9 & MO-9 & 606149 & 3526991 & $0-80$ & 10YR 5/3 & fine sandy loam & $\mathrm{n} / \mathrm{a}$ & \\
\hline $\mathrm{Y}-10$ & MO-10 & 605941 & 3526913 & $0-80$ & 10 YR $5 / 3$ & fine sandy loam & $\mathrm{n} / \mathrm{a}$ & \\
\hline $\mathrm{Y}-11$ & MO-11 & 605746 & 3526912 & $0-80$ & 10YR 5/3 & fine sandy loam & $\mathrm{n} / \mathrm{a}$ & \\
\hline $\mathrm{Y}-12$ & MO-12 & 605543 & 3526900 & $0-45$ & 10YR 5/3 & sandy clay & $\mathrm{n} / \mathrm{a}$ & $\begin{array}{l}\text { dense gravel at } \\
\text { base }\end{array}$ \\
\hline $\mathrm{Y}-13$ & MO-13 & 605450 & 3526905 & $0-80$ & 10YR 5/3 & silty loam & $\mathrm{n} / \mathrm{a}$ & \\
\hline Y-14 & MO-14 & 605414 & 3526901 & $0-80$ & 10YR 5/3 & silty loam & $\mathrm{n} / \mathrm{a}$ & \\
\hline Y-15 & $\begin{array}{c}\text { OHT-1- } \\
4\end{array}$ & $\begin{array}{l}\text { UTM } \\
\text { redacted }\end{array}$ & $\begin{array}{l}\text { UTM } \\
\text { redacted }\end{array}$ & $0-10$ & $10 \mathrm{YR} 5 / 3$ & silty loam & $\begin{array}{l}\text { small FCR } \\
\text { at } 0-4 \mathrm{~cm}\end{array}$ & $\begin{array}{l}\text { trowel test in } \\
\text { FCR cluster; site } \\
\text { OHT-1 } \\
(41 \mathrm{RV} 208)\end{array}$ \\
\hline $\mathrm{Y}-17$ & MO-16 & 604911 & 3526890 & $0-80$ & 10YR 5/3 & fine sandy loam & $\mathrm{n} / \mathrm{a}$ & \\
\hline $\mathrm{Y}-18$ & MO-17 & 604809 & 3526887 & $0-80$ & 10YR 5/3 & fine sandy loam & $\mathrm{n} / \mathrm{a}$ & \\
\hline Y-19 & MO-18 & 604715 & 3526886 & $0-50$ & 10YR 5/4 & silty loam & $\mathrm{n} / \mathrm{a}$ & bedrock at base \\
\hline
\end{tabular}




\begin{tabular}{|c|c|c|c|c|c|c|c|c|}
\hline WP No. & ST No. & Easting & Northing & $\begin{array}{l}\text { Depth } \\
\text { (cmbs) }\end{array}$ & Soil Color & Soil Texture & Artifacts & Comments \\
\hline$Y-21$ & MO-19 & 601802 & 3526824 & $0-70$ & 10YR 5/3 & fine sandy loam & $\mathrm{n} / \mathrm{a}$ & compact \\
\hline $\mathrm{Y}-22$ & MO-20 & 601902 & 3526826 & $0-80$ & 10YR 5/3 & fine sandy loam & $\mathrm{n} / \mathrm{a}$ & compact \\
\hline $\mathrm{Y}-23$ & MO-21 & 602012 & 3526828 & $0-75$ & 10YR 5/3 & silty sand & $\mathrm{n} / \mathrm{a}$ & \\
\hline Y-24 & MO-22 & 602117 & 3526832 & $0-60$ & 10YR 5/3 & clayey sand & $\mathrm{n} / \mathrm{a}$ & \\
\hline & & & & $60-80$ & 10YR 5/3 & sandy clay & $\mathrm{n} / \mathrm{a}$ & \\
\hline Y-25 & MO-23 & 602217 & 3526831 & $0-65$ & 10YR 5/3 & clay sand & $\mathrm{n} / \mathrm{a}$ & $\begin{array}{l}\text { clay dominant at } \\
\text { base }\end{array}$ \\
\hline$Y-26$ & $\mathrm{MO}-24$ & 599538 & 3527891 & $0-45$ & 10YR 5/3 & clay sand & $\mathrm{n} / \mathrm{a}$ & compact at base \\
\hline Y-27 & MO-25 & 599578 & 3527915 & $0-50$ & 10YR 5/3 & clay sand & $\mathrm{n} / \mathrm{a}$ & compact at base \\
\hline $\mathrm{Y}-30$ & MO-26 & 599666 & 3527968 & $0-45$ & $10 Y R 5 / 3$ & clay sand & $\mathrm{n} / \mathrm{a}$ & compact at base \\
\hline Y-31 & $\begin{array}{c}\text { OHT-2- } \\
1\end{array}$ & 599794 & 3528007 & $0-50$ & 10YR 5/3 & silty loam & $\mathrm{n} / \mathrm{a}$ & $\begin{array}{l}\text { gravel } \\
\text { conglomerate at } \\
\text { base }\end{array}$ \\
\hline Y-37 & MO-28 & 595231 & 3533375 & $0-60$ & 10YR 5/3 & silty sand & $\mathrm{n} / \mathrm{a}$ & $\begin{array}{l}\text { compact } \\
\text { throughout }\end{array}$ \\
\hline Y-38 & MO-29 & 595228 & 3533317 & $0-55$ & 10YR 5/3 & clay sand & $\mathrm{n} / \mathrm{a}$ & $\begin{array}{l}\text { compact } \\
\text { throughout }\end{array}$ \\
\hline Y-39 & MO-30 & 595230 & 3533189 & $0-50$ & 10YR 5/3 & silty sand & $\mathrm{n} / \mathrm{a}$ & $\begin{array}{l}\text { compact } \\
\text { throughout }\end{array}$ \\
\hline
\end{tabular}




\begin{tabular}{|c|c|c|c|c|c|c|c|c|}
\hline WP No. & ST No. & Easting & Northing & $\begin{array}{l}\text { Depth } \\
\text { (cmbs) }\end{array}$ & Soil Color & Soil Texture & Artifacts & Comments \\
\hline$Y-16$ & $\begin{array}{c}\text { OHT-1- } \\
2\end{array}$ & 605091 & 3526897 & $0-30$ & 10YR 5/3 & $\begin{array}{l}\text { silty loam with } \\
\text { abundant gravels }\end{array}$ & $\mathrm{n} / \mathrm{a}$ & $\begin{array}{l}\text { near eastern } \\
\text { boundary of site } \\
\text { OHT-1 } \\
(41 \mathrm{RV} 208)\end{array}$ \\
\hline Z-1 & TE-1 & 607505 & 3527138 & $0-40$ & 10YR 5/3 & silty sand & $\mathrm{n} / \mathrm{a}$ & \\
\hline Z-2 & TE-2 & 607497 & 3527279 & $0-45$ & 10YR 5/3 & silty sand & $\mathrm{n} / \mathrm{a}$ & \\
\hline Z-3 & TE-3 & 607372 & 3527279 & $0-50$ & 10YR 5/3 & fine sandy loam & $\mathrm{n} / \mathrm{a}$ & \\
\hline Z-4 & TE-4 & 607205 & 3527267 & $0-80$ & 10YR 5/3 & fine sandy loam & $\mathrm{n} / \mathrm{a}$ & \\
\hline Z-5 & TE-5 & 606969 & 3527264 & $0-80$ & 10YR 5/3 & fine sandy loam & $\mathrm{n} / \mathrm{a}$ & \\
\hline Z-6 & TE-6 & 606760 & 3527247 & $0-80$ & 10YR 5/3 & fine sandy loam & $\mathrm{n} / \mathrm{a}$ & \\
\hline $\mathrm{Z}-7$ & TE-7 & 606461 & 3527224 & $0-80$ & 10YR 5/3 & fine sandy loam & $\mathrm{n} / \mathrm{a}$ & \\
\hline Z-8 & TE-8 & 606271 & 3527084 & $0-80$ & 10YR 5/3 & fine sandy loam & $\mathrm{n} / \mathrm{a}$ & \\
\hline Z-9 & TE-9 & 606099 & 3526946 & $0-80$ & 10YR 5/3 & fine sandy loam & $\mathrm{n} / \mathrm{a}$ & \\
\hline Z-10 & TE-10 & 605885 & 3526917 & $0-80$ & 10YR 5/3 & fine sandy loam & $\mathrm{n} / \mathrm{a}$ & \\
\hline Z-11 & TE-11 & 605686 & 3526912 & $0-80$ & 10YR 5/3 & fine sandy loam & $\mathrm{n} / \mathrm{a}$ & \\
\hline $\mathrm{Z}-12$ & TE-12 & 605496 & 3526903 & $0-80$ & 10YR 5/3 & fine sandy loam & $\mathrm{n} / \mathrm{a}$ & \\
\hline Z-13 & TE-13 & 605161 & 3526896 & $0-40$ & 10YR 5/3 & $\begin{array}{c}\text { silty loam with } \\
\text { abundant gravels }\end{array}$ & $\mathrm{n} / \mathrm{a}$ & bedrock at base \\
\hline $\mathrm{Z}-14$ & TE-14 & 605019 & 3526894 & $0-30$ & 10YR 5/4 & $\begin{array}{c}\text { silty loam with } \\
\text { abundant gravels }\end{array}$ & $\mathrm{n} / \mathrm{a}$ & bedrock at base \\
\hline Z-15 & TE-15 & 604969 & 3526899 & $0-25$ & 10YR 5/3 & $\begin{array}{l}\text { silty loam with } \\
\text { abundant gravels }\end{array}$ & $\mathrm{n} / \mathrm{a}$ & bedrock at base \\
\hline Z-16 & TE-16 & 604863 & 3526885 & $0-20$ & 10YR 5/3 & $\begin{array}{l}\text { silty loam with } \\
\text { abundant gravels }\end{array}$ & $\mathrm{n} / \mathrm{a}$ & bedrock at base \\
\hline $\mathrm{Z}-17$ & TE-17 & 604759 & 3526892 & $0-65$ & $10 \mathrm{YR} 5 / 3$ & $\begin{array}{l}\text { silty loam with } \\
\text { abundant gravels }\end{array}$ & $\mathrm{n} / \mathrm{a}$ & bedrock at base \\
\hline Z-18 & TE-18 & 604661 & 3526884 & $0-40$ & 10YR 5/3 & $\begin{array}{l}\text { silty loam with } \\
\text { abundant gravels }\end{array}$ & $\mathrm{n} / \mathrm{a}$ & bedrock at base \\
\hline Z-19 & TE-19 & 601854 & 3526824 & $0-65$ & 10YR 5/3 & silty sand & $\mathrm{n} / \mathrm{a}$ & \\
\hline Z-20 & TE-20 & 601960 & 3526830 & $0-70$ & 10YR 5/3 & silty sand & $\mathrm{n} / \mathrm{a}$ & \\
\hline Z-21 & TE-21 & 602063 & 3526831 & $0-70$ & 10YR 5/3 & silty sand & $\mathrm{n} / \mathrm{a}$ & compact \\
\hline
\end{tabular}




\begin{tabular}{|c|c|c|c|c|c|c|c|c|}
\hline WP No. & ST No. & Easting & Northing & $\begin{array}{l}\text { Depth } \\
\text { (cmbs) }\end{array}$ & Soil Color & Soil Texture & Artifacts & Comments \\
\hline $\mathrm{Z}-22$ & TE-22 & 602165 & 3526831 & $0-65$ & 10YR $5 / 3$ & silty sand & $\mathrm{n} / \mathrm{a}$ & compact \\
\hline $\mathrm{Z}-23$ & TE-23 & 602317 & 3526837 & $0-70$ & 10 YR $5 / 3$ & silty sand & $\mathrm{n} / \mathrm{a}$ & compact \\
\hline $\mathrm{Z}-24$ & TE-24 & 599503 & 3527870 & $0-30$ & 10YR 5/3 & silty sand & $\mathrm{n} / \mathrm{a}$ & \\
\hline Z-25 & TE-25 & 599629 & 3527938 & $0-30$ & 10YR 5/3 & silty sand & $\mathrm{n} / \mathrm{a}$ & \\
\hline Z-26 & TE-26 & 599748 & 3528004 & $0-35$ & 10YR 5/3 & silty sand & $\mathrm{n} / \mathrm{a}$ & \\
\hline $\mathrm{Z}-27$ & TE-27 & 599848 & 3528009 & $0-40$ & 10 YR $5 / 3$ & $\begin{array}{l}\text { silty sand with } \\
\text { heavy caliche } \\
\text { inclusions }\end{array}$ & $\mathrm{n} / \mathrm{a}$ & compact \\
\hline Z-28 & TE-28 & 595225 & 3532938 & $0-80$ & 10YR 5/3 & silty sand & $\mathrm{n} / \mathrm{a}$ & \\
\hline Z-29 & TE-29 & 595231 & 3532986 & $0-70$ & 10YR 5/3 & silty sand & $\mathrm{n} / \mathrm{a}$ & \\
\hline
\end{tabular}

